Autor: Humberto Navarro de Mesquita Junior

\title{
Análise temporal com sensor orbital de unidades fisionômicas de cerrado na Gleba Pé-de-Gigante (Parque Estadual de Vassununga - SP).
}

Dissertação apresentada ao Departamento de Ecologia do Instituto de Biociências da Universidade de São Paulo, para obtenção do grau de mestre em Ecologia dos Ecossistemas Terrestres e Aquáticos.

Orientador: Dr $^{\mathrm{a}}$ Marisa Dantas Bitencourt

Apoio: $\mathrm{CNPq}$ - Conselho Nacional de Desenvolvimento Científico e Tecnológico FAPESP - Fundação de Amparo à Pesquisa do Estado de São Paulo 
Dedico

próximas gerações de cientistas. 


\section{Agradecimentos}

Ao Conselho Nacional de Desenvolvimento Científico e Tecnológico pela bolsa concedida e à Fundação de Amparo à Pesquisa do Estado de São Paulo pelo auxílio financeiro ao projeto.

Ao Departamento de Águas e Energia Elétrica do Estado de São Paulo, especificamente ao Centro Tecnológico de Hidráulica, pelos dados meteorológicos fornecidos. Aos funcionários da biblioteca do Instituto Brasileiro de Geografia e Estatística de São Paulo e Instituto Geológico de São Paulo pela doação de uma carta geológica.

Ao IGC - Instituto de Geografia e Cartografia do Estado de São Paulo e ao Departamento de Estradas de Rodagem, pelas cópias das cartas topográficas

À Secretaria de Meio Ambiente do Estado de São Paulo e ao Departamento de Geografia da Faculdade de Filosofia Letras e Ciências Humanas da Universidade de São Paulo (USP), por permitir o uso das imagens digitais destes órgãos.

Prof. Dr. Magalhães do Instituto de Geofísica e Astronomia da USP pelos valiosos esclarecimentos sobre a mecânica celeste.

Ao Dr. Flavio Ponzoni e MSc. Helena Franca do Instituto Nacional de Pesquisas Espaciais pelo esclarecimento, atenção e estímulo à pesquisa em sensoriamento remoto.

Ao Instituto Florestal pelo apoio, cedendo alojamento e permitindo a realização das visitas a unidade de conservação.

Aos Funcionários do Departamento de Ecologia da USP: Paulo César, Lenilda, pelo apoio técnico em campo ou nos laboratórios, às secretárias Dalva e Bernadete que me auxiliaram na resolução de diversos problemas de escritório. E a todos pelo apoio e companhia.

À $\operatorname{Dr}^{\mathrm{a}}$ Marisa Dantas Bitencourt que soube indicar caminhos nos momentos de insegurança, pela competência, e principalmente por todas oportunidades concedidas para o desenvolvimento e formação.

Ao Professor Dr. Waldir Mantovani, pelo apoio e incentivo à investigação e valiosa experiência em ecologia vegetal. À Dr ${ }^{\mathrm{a}}$. Vânia Regina Pivello, pelas críticas e 
sugestões sempre inovadoras e de grande importância na estruturação e organização das idéias.

À Luis Fillipe e Vânia Korman pelo apoio nos trabalhos de campo. À Claudia Nagako Shida, pela companhia, apoio e discussão no laboratório e ao MSc. Marco Antônio Batalha, pela companhia e apoio nas atividades de campo, bem como pelo auxílio na identificação das espécies do cerrado.

Ao Dr. Emílio Moran pela oportunidade de realizar o treinamento no Anthropological Center of Training and Environmental Changes Research no estado de Indiana nos Estados Unidos. E aos Professores Dr. Eduardo e Dr. Glen Green pela oportunidade de discussão do trabalho.

Aos meus colegas de turma pela amizade e confiança oferecidas no dia à dia de trabalho.

A todos os professores do departamento de Ecologia do Instituto de Biociências da USP e do Departamento de Botânica da UNICAMP, pelos cursos oferecidos que contribuíram substancialmente para minha formação.

À Cristina e Helena (minhas irmãs) que me auxiliaram na digitação dos dados e à Dra. Eliane Robert Moraes e Wilson Hanashiro de Carvalho na correção do texto. E aos meus pais que auxiliaram em todos os momentos.

À todos meus amigos e familiares pelo apoio nos momentos de dificuldade e felicidade, sem os quais não poderia ter realizado este trabalho. 


\section{Índice de Tabelas}

Tabela 1.1 - Variação temporal da área ocupada por cerrado senso lato, no estado de São Paulo.

Tabela 3.4.1 - Fitofisionomias, classes IVDN e descrição baseada em observações de campo. Fonte: Bitencourt et alii (1997).

Tabela 3.5.1 - Variações dinâmicas de dados pós-calibrados do TM para dados
processados nos EUA (para imagens processadas após 15 de Janeiro de

Tabela 3.5.1 - Variações dinâmicas de dados pós-calibrados do TM para dados
processados nos EUA (para imagens processadas após 15 de Janeiro de 1984).

Tabela 4.1. - Coordenadas dos pontos de referência obtidas na base cartográfica e distância Euclidiana em relação aos pontos de referência obtidos por GPS e nas 5 imagens em diferentes datas.

Tabela 5.1 - Variação dos valores máximo, mínimo e médio de altitude e declividade, e pg.047 a área em hectares (projeção horizontal da área superficial) das áreas de ocorrência das fitofisionomias.

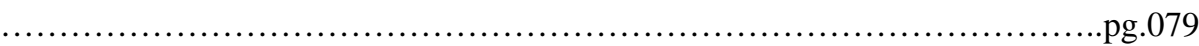

Tabela 5.2 - Porcentagem de pontos coincidentes e pontos de confusão, entre os pontos registrados com o GPS e as áreas de ocorrência.

Tabela 10.1. - Valores médios de IVDN, biomassa epígea, teor de umidade e número de amostras utilizadas (entre parênteses) para comparação, obtidos em (Bitencourt-Pereira, 1986).

Tabela 10.2. - Valores de IVDN, Biomassa e Teor de Umidade Médios e o número de amostras utilizadas (entre parênteses) para a média na comparação (Santos, 1988).

- Valores médios de IVDN obtidos por França (1994) e o número de áreas

Tabela 10.3. - Valores médios de IVDN obtidos por França (1994) e
amostrais utilizadas (entre parênteses) na comparação.

Tabela 10.4. - Descrição das fitofisionomias observadas em campo, nas transeções de Leste para Oeste e de Norte para Sul.

Tabela 10.5. - Dados de campo utilizados para fazer o ajuste da superfície (imagem MDT com resolução de $10 \mathrm{~m} \times 10 \mathrm{~m}$ ) das transeções sobre o morro, com as imagens IVDN com resolução de $30 \mathrm{~m}$ x 30m.

Tabela 10.6. - Cor do solo seco e úmido, a textura (medida grosseira) e a fitofisionomia onde foi coletada a amostra.

- Média e o desvio padrão extraídos das áreas de ocorrência, obtidas a

Tabela 10.7. - Média e o desvio padrão extraídos das áreas de ocorrência, obtidas a
partir das imagens: IVDN, faixa do vermelho, do infravermelho próximo e do infravermelho médio. 


\section{Índice de Figuras}

Figura 2.1.1 - Comportamento espectral dos três principais alvos da superfície terrestre: vegetação (a - herbáceo e b - arbóreo), água (d - límpida e c turva) e solo (e - argiloso e f - arenoso), nas faixas espectrais do visível 1,2,3 e infravermelho 4,5 e 7 ("Landsat 5 - Thematic Mapper"). Fonte: modificado a partir de Lillesand \& Kiefer, 1995.

Figura 2.1.2 - Variação anual (92-93) do IVDN no campo cerrado do Parque Nacional de Emas - GO e da precipitação no mesmo período. Fonte: França (1994).

Figura 3.1.1 - Localização da área de estudo no contexto nacional, estadual e regional.

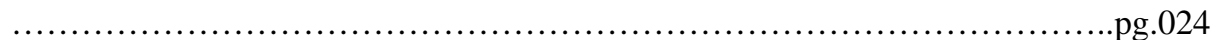

Figura 3.1.2 - Climadiagrama segundo o método de Walter (1955 apud. Walter et alii 1985), estação meteorológica de Santa Rita do Passa Quatro (C4-107, DAEE).

Figura 3.1.3 - Gradiente fisionômico das fisionomias de cerrado senso lato da gleba Péde-Gigante e as variações decorrentes da sazonalidade (período de estiagem e de máxima precipitação). Fonte: Bitencourt \& Mesquita Jr (em impressão).

Figura 3.4.1 - Mapa utilizado em campo para a localização das manchas, com os intervalos de valores das 9 classes de índice de vegetação que ocorrem na gleba Pé-de-Gigante. Os pontos em azul correspondem a posição aproximada dos mesmos na imagem. Imagem índice de vegetação a partir das imagens de 05/07/95 (Bitencourt et alii, 1997).

Figura 3.4.2 - Mapa preliminar das fitofisionomias observadas em campo, o mapa foi produzido a partir de imagem IVDN de julho de 1995 (Bitencourt et alii, 1997).

Figura 4.1 - a.) Mapa topográfico da gleba Pé-de-Gigante com a as cotas altimétricas, as rodovias que delimitam a área e a rede de drenagem. Os números em vermelho indicam os pontos de referência geográfica. b.) Mapa hipsométrico da área de estudo, as cores representam as classes de elevação do terreno.

Figura 4.2. - a.) Imagem MDT; b.) Imagen de declividade ${ }^{7}$;.) Imagem de orientação pg.045 das vertentes ${ }^{8}$; d.) Imagem com a área selecionada com a orientação das vertentes Norte, Sul, Leste e Oeste, com declividade superior a 7 graus.

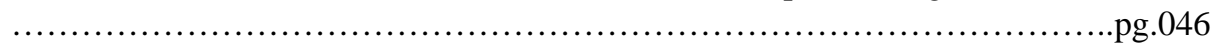

Figura 4.3. - Representação os desvios, baseados na distância euclidiana, de cada ponto registrado com o GPS nos 10 locais de referência geográfica em relação a média (azul), e a representação dos desvio da média acumulada em relação a média obtida para todos os pontos amostrados (vermelho). As retas em verde escuro representam os desvios esperados para um único posicionamento $(100 \mathrm{~m})$ e a reta em verde claro os desvios esperados para a média de 10 posicionamentos $(30 \mathrm{~m})$.

Fig. 4.4. - a.) Variação anual média da umidade relativa, insolação direta e da amplitude térmica. b.) Variação diária do fotoperíodo ao longo de um ano, os dados referem-se ao ano de 1996 (Observatório Nacional, 1996). 
Fig. 4.5. - a.) Variação diária das temperaturas máxima e mínima absolutas e amplitude térmica, estação meteorológica de Santa Rita do Passa Quatro (C4-107, DAEE). b.) Precipitação diária acumulada ao longo do período de estudo, estação meteorológica de Santa Rita do Passa Quatro (C4-107, DAEE). As setas indicam a data de aquisição das imagens de satélite.

Figura 5.1 - Perfil diagrama da fisionomia de campestre, neste caso sendo representada, pelo campo úmido. Estão representados indivíduos encontrados na parcela de $2,5 \mathrm{~m} \times 1,0 \mathrm{~m}$. As letras representam as espécies. indivíduos encontrados na parcela de $10 \mathrm{~m}$ x $2 \mathrm{~m}$. As letras representam as espécies. .................

Figura 5.3 - Perfil diagrama da fisionomia de cerrado senso estrito. Estão representados indivíduos encontrados na parcela de $10 \mathrm{~m}$ x $2 \mathrm{~m}$. As letras representam as espécies.

Figura 5.4 - Perfil diagrama da fisionomia de cerrado com herbáceo ralo. Estão representados indivíduos encontrados na parcela de $15 \mathrm{~m}$ x $2 \mathrm{~m}$. As letras representam as espécies.

Figura 5.5 - Perfil diagrama da fisionomia de cerradão. Estão representados indivíduos .pg.056 encontrados na parcela de $25 \mathrm{~m}$ x $2 \mathrm{~m}$. As letras representam as espécies.

Figura 5.6 - Perfil diagrama da fisionomia de floresta estacional semidecidual. Estão pg.057 representados indivíduos encontrados na parcela de $25 \mathrm{~m}$ x $2 \mathrm{~m}$. As letras representam as espécies.

Figura 5.7- Distribuição de indivíduos e volume por classes de altura, para as fitofisionomias amostrada no estudo fitossociológico.

Figura 5.8. - Imagens IVDN de julho de 1995, agosto de 1995, janeiro de 1996, julho de 1996 e junho de 1997.

Figura 5.9. - Posição das transeções sobre o morro, exemplificada, nas imagens de agosto de 95 e de janeiro de 1996.

Figura 5.10. - Variação do IVND médio, nas cinco datas das imagens, nas transeções Norte-Sul (acima) e Oeste-Leste (abaixo); os IVDN estão relacionados com os respectivos dados obtitidos em campo: iluminação relativa e descrição dos tipos físionômicos.

Figura 5.11. - Valores do IVDN médio para cada fisionomia descrita na transeção sobre o morro. As caixas sobre as retas indicam os intervalos e as datas utilizadas para a separação da área de ocorrência da fisionomia.

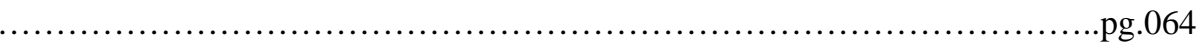

Figura 5.12. - Mapa das áreas de maior probabilidade de ocorrência das fisionomias.

Figura 5.13. - Fluxograma resumido das atividades realizadas para a delimitação das áreas de ocorrência das fitofisionomias na área de estudo. 
Figura 5.14. - Variação do IVDN médio obtido nas fitofisionomias da gleba Pé-deGigante (extraído das áreas de ocorrência) e os IVDN médios obtidos por França (1994) Santos (1988) Bitencourt-Pereira (1986).

Figura 5.15. - Variação da reflectância média das fitofisionomias obtida por extração dos valores que ocorrem nas áreas de ocorrência.

Figura 5.16. - Posição dos pontos selecionados para a coleta de solo superficial na área de estudo (a) e fotografias da superfície do solo na ocasião da coleta da amostra (b).

Figura 5.17. - a.) Variação da cobertura vegetal nas fisionomias medida através das fotografias verticais da vegetação. b.) Variação da luminosidade relativa (medida da iluminação, com luxímetro, acima do dossel e no nível do solo) em algumas das fitofisionomias observadas na área de estudo.

Figura 5.18. - Médias extraídas de cada vertente em relação a média extraída para os terrenos planos (0 a 7 graus), obtidas para as área de ocorrência: do campo cerrado, cerrado senso estrito e cerrado com herbáceo ralo. As média foram extraídas nas diferentes datas de aquisição das imagens: IVDN, faixa do vermelho e faixa do infravermelho próximo.

Figura 5.19. - Imagens de iluminação relativa para o mês de julho (ângulo de pg.085 inclinação solar $=27^{\circ}$ e $42^{\circ}$ de azimute), agosto (ângulo de inclinação solar $=34^{\circ}$, e $42^{\circ}$ de azimute) e janeiro (ângulo de elevação solar $=45^{\circ}$ e $44^{\circ}$ de azimute). 


\section{Sumário}

Índice de Tabelas

Índice de Figuras

.pg. v

Resumo

pg. vi

Abstract

pg.001

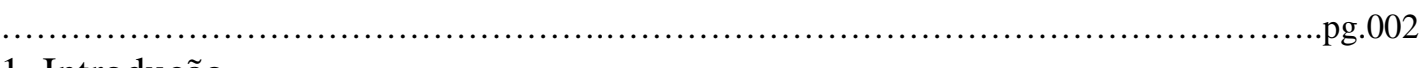

1. Introdução

pg.003

2. Revisão de Literatura

.pg.007

2.1. Sensoriamento Remoto Orbital

pg.007

2.2. Geoprocessamento

.pg.016

2.3. Fisionomias de cerrado

pg.020

3. Materiais e Métodos de Pesquisa

.pg.022

3.1. Objeto de Estudo

pg.023

3.2. Instrumentação

.pg.028

3.3. Aquisição e Registro dos Dados

pg.029

3.3.1. Consulta Bibliográfica

.pg.029

3.3.2. As imagens de satélite

pg.029

3.3.3. Dados Meteorológicos

.pg.030

3.3.4. Mapas temáticos

..pg.031

3.3.5. Dados de Campo

pg.031

3.3.5.1. Diagramas de perfil

pg.031

3.3.5.2. Fotografias verticais

.pg.032

3.3.5.3. Fotografias da paisagem

pg.032

3.3.5.4. Luminosidade

pg.033

3.3.5.5. Estrutura das fisionomias de cerrado

pg.033

3.3.5.6. Posicionamentos com o GPS

pg.034 
3.3.5.7. Registro da Cor do Solo superficial

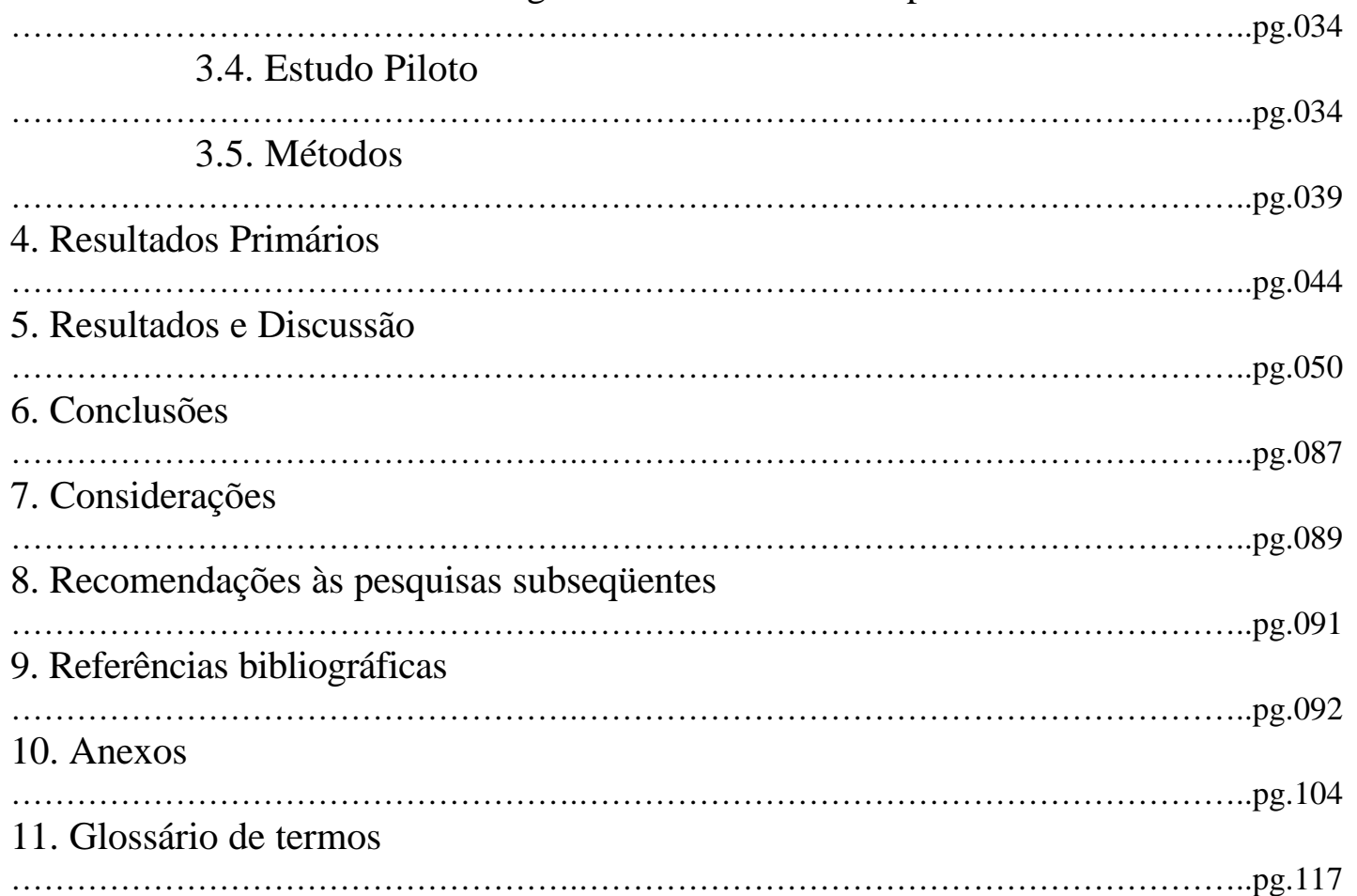




\section{Resumo}

Este trabalho tem como objetivo principal calibrar as assinaturas espectrais das fisionomias do cerrado sazonalmente de modo a fornecer subsídios para o manejo e a conservação dos remanescentes do mesmo. O local de estudo, a gleba Pé-de-Gigante (Parque Estadual de Vassununga - SP), possui vários morfotipos de cerrado senso lato desde os florestais até os campestres. Assim, usando imagens Landsat "Thematic Mapper" nas faixas do vermelho (TM-3) e infravermelho próximo (TM-4), foram obtidas imagens índice de vegetação (IVDN), que destacam a densidade de folhas verdes. As classes fisionômicas foram identificadas espectral e sazonalmente. Para validar o método, construiu-se um mapa com as áreas de probabilidade de ocorrência das fitofisionomias da gleba utilizando os IVDN do período de estiagem, pré-estiagem e de chuvas. Após teste com dados de campo, foram extraídos os IVDN de todas as classes em 5 datas distintas para estabelecer o intervalo de variação. Com um modelo digital do terreno foram produzidos mapas de declividade e de orientação de vertentes. Da análise cruzada obteve-se um mapa com 5 zonas (Norte, Sul, Leste, Oeste e o plano) que orientou a extração do IVDN nas 5 datas, visando testar o efeito da topografia no índice. Paralelamente, as classes de IVDN foram comparadas com a literatura e examinou-se a assinatura espectral das fitofisionomias no vermelho, no infravermelho próximo e no infravermelho médio. Observou-se uma forte influência das condições climáticas nas fisionomias de cerrado, ao longo do ano, através dos valores do IVDN. 


\section{Abstract}

The main goal of this dissertation is to calibrate the cerrado vegetation physiognomies (Brazilian savannas) with their seasonal spectral signatures to help the monitoring and the conservation of their remnants. The study area is the cerrado Péde-Gigante (belonging to State Park of Vassununga in Santa Rita do Passa Quatro SP). Using NDVI images derived from TM-Landsat (red and near infrared), the physiognomic classes were identified spectral and seasonally. To validate the method, a map of areas of probable physiognomies occurrence were build using NDVI images from dry and wet season. After field checking, the NDVI values of 5 dates were extracted to establish the NDVI range of each physiognomy. Using the digital terrain model, slope and aspect maps were used to prepare another map with 5 zones $(\mathrm{N}, \mathrm{S}$, W, E and flat), looking for to test the topographic effect in NDVI. Added to this, the NDVI classes were compared with the literature, as well as the separate signature in red, near infrared and middle infrared. It was noticed a strong weather condition influence over the physiognomies along the seasons, corroborated by the NDVI variation classes obtained from satellite imagery. 


\section{Introdução}

Após a revolução industrial, dado o grande desenvolvimento econômico, grandes áreas de vegetação natural foram e estão sendo substituídas por áreas urbanas ou agroecossistemas. Nas últimas décadas o modelo de desenvolvimento adotado no Brasil e, particularmente no estado de São Paulo, tem sido muito predatório aos recursos naturais, principalmente à cobertura vegetal natural, com conseqüências em todo meio biótico (Leitão-Filho \& Azevedo, 1989; Milano, 1993). O cerrado é um dos tipos de vegetação do estado de São Paulo que tem sofrido grandes perdas em tamanho de área de ocorrência (SMA, 1997).

O cerrado, com diversidade biológica intrínseca, outrora existente no estado de São Paulo, teve grande parte de sua cobertura vegetal substituída por atividade agrícola e outras resultantes da ocupação humana (Castro, 1987; Kronka, em impressão). Segundo o inventário florestal do Instituto Florestal (Kronka et alii, 1993), a cobertura dos tipos fisionômicos de cerrado senso lato tiveram grande redução, conforme mostra a tabela abaixo.

Tabela 1.1 - Variação temporal da área ocupada por cerrado senso lato, no estado de São Paulo.

\begin{tabular}{|l|c|c|}
\hline Fisionomia de cerrado & $\mathbf{1 9 7 1 - 1 9 7 3}$ & $\mathbf{1 9 9 2}$ \\
\hline cerradão & $606.022 \mathrm{ha}$ & $73.681 \mathrm{ha}$ \\
\hline cerrado senso estrito: & $784.990 \mathrm{ha}$ & $162.838 \mathrm{ha}$ \\
\hline campo cerrado & $148.390 \mathrm{ha}$ & $1.392 \mathrm{ha}$ \\
\hline TOTAL & $1.539 .402 \mathrm{ha}$ & $237.912 \mathrm{ha}$ \\
\hline
\end{tabular}

Fonte: Kronka et alii (1993) e Kronka et alii (em impressão)

Dessa forma, surgiu a necessidade de um sistema de unidades de áreas protegidas que assegurasse a conservação das manchas de cerrado ainda existentes (De Mello-Filho; 1993). O antigo Instituto Brasileiro de Desenvolvimento Florestal (IBDF), atual Instituto Brasileiro de Meio Ambiente e Recursos Naturais Renováveis (IBAMA), instituiu o Plano do Sistema de Unidades de Conservação do Brasil (IBDF, 1982). Esse plano procurava, num único documento e de forma integrada, associar as atividades que deveriam ser realizadas nas áreas de conservação. Contudo, o documento tinha caráter administrativo e não considerava as fragilidade de cada 
tipo de vegetação. O zoneamento, considerando as características da vegetação dessas unidades, principalmente as de pequenas dimensões, é muito importante para a administração e manejo, no sentido de assegurar as condições de sua conservação nas áreas de cerrado (Câmara; 1993).

As unidades de conservação do estado têm diretrizes administrativas organizadas através dos planos de manejo, que freqüentemente incluem: inventário, delimitações, zoneamento, programas e avaliações (IBDF, 1982). Em geral, este procedimento é feito nas unidades de conservação de grandes áreas, e conseqüentemente, de maior interesse (ex. Plano de Manejo dos Parques Nacionais e Estaduais). As unidades pequenas geralmente não são tratadas da mesma forma. Em geral, estas unidades de conservação apresentam maior instabilidade. Entre outras características, possuem menor relação perímetro por área e menor número de indivíduos por população, diminuindo, assim, a capacidade reprodutiva na comunidade.

A questão da conservação deve ser ressaltada à medida que os cerrados foram classificados como um dos ecossistemas de maior risco de extinção em São Paulo, em virtude da fronteira agrícola (SMA, 1997). Daí a necessidade de uma metodologia rápida e eficiente de acompanhar o estado das áreas com vegetação natural, que pode ser obtida através do sensoriamento remoto orbital.

O mapeamento das áreas naturais, com a utilização de sensoriamento remoto, tem sido uma das formas dos órgãos governamentais avaliarem e acompanharem a situação dos remanescentes com vegetação natural. No estado de São Paulo, as principais iniciativas de utilização de sensores remotos para o diagnóstico da vegetação natural se deu com fotografias aéreas pancromáticas, constituindo-se os primeiros inventários florestais com esta metodologia (Borgonovi \& Chiarini, 1965 e Borgonovi, et alii 1967). A seguir outros inventários foram realizados (Serra-Filho et alii, 1974; Kronka et alii 1993), e a utilização de sensores remotos orbitais passou a ter um papel importante nas análises. No mesmo período, a Secretaria Estadual do Meio Ambiente de São Paulo realizou o projeto Olho Verde, que consistiu no acompanhamento da situação das áreas com vegetação natural no estado, com a utilização de imagens do satélite Landsat. 
Para fazer um bom uso do sensoriamento remoto orbital, é necessário conhecer a ecologia dos ecossistemas em questão e saber que a resposta espectral da vegetação varia em função das condições de iluminação e em função da qualidade e quantidade de folhas. Variações fisiológicas do tipo floração e perda de folhas também podem intervir na resposta espectral (Gates et alii, 1965; Tucker, 1980).

Na maior parte dos casos de utilização das imagens de satélite em estudos de ecossistemas naturais, utiliza-se apenas uma imagem na data de menor recobrimento de nuvens. Porém, a vegetação está sujeita a alterações fisiológicas decorrentes da sazonalidade. Estas variações da vegetação e do ambiente (ex. ângulo de elevação solar, condições atmosféricas) no decorrer de um ano podem contribuir para aumentar a possibilidade de interpretação equivocada de dados remotamente sensoriados.

O cerrado é uma vegetação com características peculiares e possui variações fisionômicas contrastantes. Geralmente, ocorre em regiões com sazonalidade marcada por um período de estiagem seguido por período chuvoso (Eiten, 1972).

As fisionomias de cerrado variam entre si num gradiente, em decorrência da proporção entre o componente herbáceo e o arbóreo. Um dos extremos é representado pela fisionomia campestre, com ausência do componente arbóreo, e o outro a fisionomia florestal, com ausência do componente herbáceo. Esta configuração enquadra-se no conceito floresta-ecótono-campo proposto por Coutinho (1978), no qual estas formas de vida ocorrem em tensão ecológica, ou seja, onde as condições do meio físico podem favorecer mais uma forma de vida em detrimento da outra. Assim, a ocorrência de uma fisionomia claramente reflete as condições ecológicas locais, como: condições físicas ou químicas do solo (Sarmiento, 1992; Furley, 1996), geomorfologia, topografia, freqüência de queimadas, pastoreio, etc.

De maneira geral, os componentes herbáceo e arbóreo do cerrado têm características ecofisiológicas diferenciadas para aproveitamento de recursos hídricos, que conferem as mesmas estratégias diferenciadas para sobreviver a variações sazonais das condições do ambiente físico (Rawitscher et alii, 1943). Por estratégias diferenciadas compreende-se diferente padrão anual de senescência e abscisão foliar. Desse modo, para utilizar dados remotamente sensoriados é preciso levar em conta 
estes efeitos para não cometer o risco de subestimar ou superestimar a área de uma ou outra fisionomia.

Os levantamentos estaduais feitos por interpretação visual em reprodução fotográfica de imagens de satélites têm suscitado dúvidas quanto à classificação, uma vez que o método utilizado (composição colorida) não tem o mesmo padrão de cor quando se muda de uma cena para outra. Como todo o estado de São Paulo envolve por volta de 16 cenas com datas distintas, o erro de identificação é ainda mais ampliado. Para minimizar estes erros, tem se buscado métodos de interpretação digital para compensar os efeitos atmosféricos e de condições de iluminação (Robinove, 1982). No caso dos cerrados este erro pode ser ainda maior por conta das variações fenológicas resultantes do contraste sazonal.

Este trabalho tem como finalidade calibrar sazonalmente as assinaturas espectrais das fisionomias do cerrado, de modo a fornecer subsídios para o manejo e a conservação de seus remanescentes. A área de estudo é a gleba Pé-de-Gigante (gleba do Parque Estadual de Vassununga), Santa Rita do Passa Quatro - SP. Este local possui várias fisionomias de cerrado senso lato, desde os florestais até os campestres.

Para realizar a análise sazonal das fisionomias, foram utilizados dados espectrais orbitais na forma digital em 5 diferentes datas, dados climatológicos, dados cartográficos e dados obtidos em campo. Estes dados foram combinados por técnicas de geoprocessamento.

Os dados de campo foram coletados no período de estiagem e de máxima precipitação. Estes dados, juntamente com os demais, serviram para selecionar as áreas de provável ocorrência das fisionomias, que foram utilizadas na análise espectral sazonal.

Para avaliar a variação sazonal espectralmente, foram utilizados dados orbitais que, relacionados aos dados climatológicos, correspondem às épocas de estiagem, máxima precipitação e de pré-estiagem. As fisionomias de cerrado foram associadas ao índice de vegetação diferença normalizada (IVDN), que é diretamente proporcional à densidade de vegetação por área.

Para validar o uso de IVDN como indicador de morfotipos de cerrado e suas variações sazonais, relacionaram-se as 5 imagens IVDN, as condições de iluminação e 
relevo, que são dois fatores que mais comprometem a resposta espectral. Foram feitas ainda considerações sobre a cor do solo que também pode influenciar o IVDN.

\section{Revisão de Literatura}

\subsection{Sensoriamento Remoto Orbital}

Sensoriamento remoto é a ciência e a arte de observar um alvo sem ter contato físico com o mesmo, baseando-se apenas na interação deste alvo com a radiação eletromagnética (Lillesand \& Kiefer, 1995). O registro dessas interações é feito pelo rastreamento regular da interação da radiação eletromagnética em diferentes faixas espectrais, formando distintas imagens. A interação de cada faixa com cada alvo é função da estrutura física e química do alvo e do comprimento de onda da radiação eletromagnética. A radiância guarda uma relação direta com a reflectância, e é, por sua vez, característica de cada alvo (assinatura espectral do alvo). Como cada alvo interage diferentemente com a radiação eletromagnética de cada faixa espectral, o resultado é uma ampliação do espectro de observação dos alvos terrestres através de sensores remotos aéreos ou orbitais.

Com o avanço das tecnologias espaciais, as imagens obtidas por sensores orbitais tornaram-se um grande aliado no mapeamento da vegetação. Com o surgimento do satélite da série Landsat "Thematic Mapper" (TM) desde 1983, a resolução no terreno melhorou de 80 para 30 metros, a resolução espectral ${ }^{10}$ (glossário de termos item 11) de 4 para 7 faixas (três faixas no visível, uma no infravermelho próximo, duas no infravermelho médio e uma no termal), e este aliado ficou ainda mais forte.

A figura 2.1.1. apresenta as modificações nos alvos que podem alterar a reflectância dos mesmos. A presença de particulados em suspensão faz a reflectância da água aumentar no visível. A textura, composição e cor do solo podem modificar a quantidade de radiação que reflete do alvo. A clorofila absorve boa parte da radiação 
na faixa do visível, com exceção da faixa estreita do verde. Assim, o aumento na quantidade de biomassa verde ocasiona a diminuição da radiação deste alvo, que reflete na faixa do visível. A quantidade de fitomassa é diretamente proporcional à quantidade de radiação que reflete na faixa do infravermelho próximo. A radiação nesta faixa se deve às variações no índice de refração do meio celular e dos espaços intracelulares. Deste modo, quanto maior a quantidade de espaços intracelulares do mesófilo, mais reflexões sucessivas, e maior a radiação refletida pela folha. A faixa do infravermelho médio está relacionada com a quantidade de água no tecido celular. A água apresenta baixa reflectância do infravermelho próximo. Assim, quanto maior a quantidade de folhas com água nos tecidos, menor será a radiação refletida.

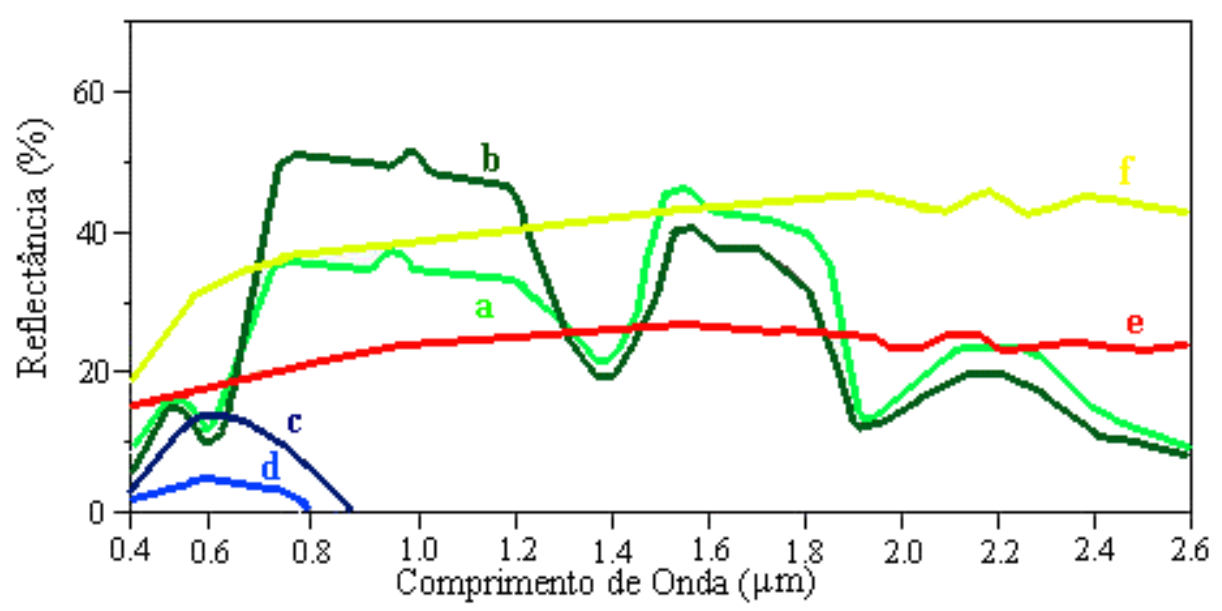

Figura 2.1.1 - Comportamento espectral dos três principais alvos da superfície terrestre: vegetação (a - herbáceo e b - arbóreo), água (d - límpida e c - turva) e solo (e - argiloso e f arenoso), nas faixas espectrais do visível 1,2,3 e infravermelho 4,5 e 7 ("Landsat 5 Thematic Mapper”). Fonte: modificado a partir de Lillesand \& Kiefer, 1995.

O ponto alto das imagens orbitais é a multispectralidade: quanto mais faixas, mais informações se tem sobre um alvo. No caso específico da vegetação, as faixas

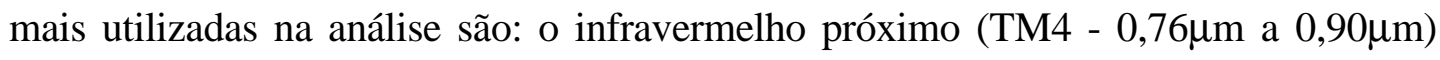
com valores de maior reflectância indicando mais biomassa verde; o infravermelho

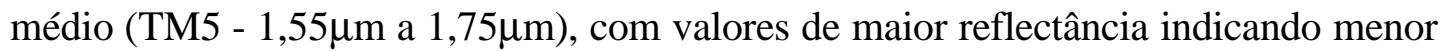

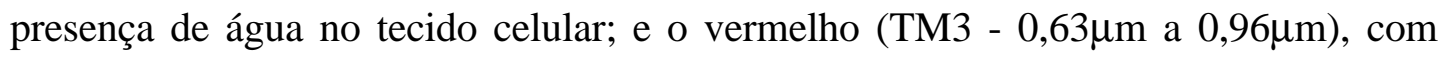
valores de maior reflectância indicando menor quantidade de clorofila. 
Gaussman (1984) estudou a reflectância de folhas na sombra e no sol de Valencia orange (Citrus sinensis (L.) Osbeck) e correlacionou a quantidade de clorofila, o volume de ar, a quantidade de água e a espessura da folha com a reflectância na faixa do visível. A quantidade de clorofila apresentou maior correlação negativa com a reflectância na faixa do vermelho; e observou que folhas na sombra apresentam menor reflectância na faixa do visível em relação as folhas no sol.

No Brasil, alguns estudos esboçavam a tendência de utilização de dados remotamente sensoriados para a classificação das fisionomias de cerrado senso lato (Aoki \& Santos, 1979; Santos \& Aoki, 1980). O desenvolvimento de novas tecnologias, associadas à capacidade de obtenção de dados em nível nacional, possibilitaram aprimorar métodos para obtenção de informações ecológicas da vegetação e reconhecer a distribuição dos diversos morfortipos de cerrado em escala regional (Carvalho, 1986).

Saraiva et alii (1987) testaram as sete faixas espectrais quanto à capacidade de discernir áreas com fisionomias de cerrado senso lato, reflorestamentos de Pinus e de Eucalipto, concluindo que as faixas 3, 4 e 5 foram as que apresentaram melhor capacidade de separação.

Com o objetivo de reduzir os efeitos atmosféricos e a condição de iluminação, tem se desenvolvido, desde o início da década de 70, vários modelos matemáticos que relacionam assinatura espectral e parâmetros mensuráveis no campo. Existem vários índices, cada um visando indicar um parâmetro de campo. Os índices mais utilizados para o estudo da cobertura vegetal são os índices de vegetação. Estes são diretamente proporcionais à fitomassa foliar verde e sempre relaciona as respostas espectrais do vermelho e do infravermelho próximo, sendo por vezes relacionadas outras faixas também. Bitencourt-Pereira (1986) fez uma boa revisão bibliográfica dos índices de vegetação.

Visando um método não destrutivo de estimativa da fitomassa e posterior estimativa de produtividade, os índices de vegetação foram muito testados na previsão de safras, como sugerem os parágrafos seguintes.

A relação da vegetação com as faixas do vermelho e infravermelho próximo vem sendo estudada desde a origem das primeiras fotografias infravermelho falsa-cor 
(desde a segunda guerra mundial), para conhecimento do estado senil das folhas de áreas com vegetação (Polcyn, 1969). O índice de vegetação diferença normalizada relaciona estas duas faixas espectrais num único índice diretamente relacionado à vegetação: quanto maior o índice, maior é a quantidade de folhas verdes. O vermelho é inversamente proporcional à quantidade de fitomassa verde e o infravermelho próximo é diretamente relacionado à fitomassa verde. $\mathrm{O}$ índice de vegetação diferença normalizada é simples e relaciona estas duas variáveis de forma inversa, para obter um valor diretamente proporcional a fitomassa verde, e normalizado, ou seja os valores variam sempre de -1 até 1 . Este índice vem sendo amplamente aplicado na análise da vegetação pois são necessárias apenas duas faixas dos espectro (o vermelho e o infravermelho próximo) e os resultados têm mostrado alta relação com diversos parâmetros da vegetação. O índice de vegetação diferença normalizada, como é conhecido atualmente, foi apresentado por Rouse em 1974 (apud Tucker, 1979) apenas como Índice de Vegetação (IV); e o Índice de Vegetação Transformado (IVT) que é a raiz quadrada da soma do IV com 0,5. A soma e a transformação da raiz quadrada, foram efetuadas para evitar resultados negativos.

$$
\mathrm{IV}=(\mathrm{MSS} 7-\mathrm{MSS} 5) /(\mathrm{MSS} 7+\mathrm{MSS} 5) \text { e o } \mathrm{IVT}=\sqrt{(\mathrm{IV}+0,5)}
$$

As faixas do MSS7 e MSS5 correspondem, respectivamente, ao vermelho e ao infravermelho próximo. Rouse (1974 apud Tucker 1979) observou que o índice apresentou alta relação com a biomassa verde de plantações de trigo. Tucker (1979) corroborou estes resultados, relacionando variáveis do componente herbáceo com o TVI concluindo que o mesmo é muito sensível à quantidade de fitomassa verde.

Choudhury (1987) mostrou as relações existentes entre a radiação fotossinteticamente ativa absorvida e os índices de vegetação; depois Wiengand et alii (1991) estudaram a relação entre o IVDN e vários parâmetros da vegetação em áreas cultivadas. Foram analisados o índice de área foliar, a radiação fotossinteticamente ativa e a produtividade da colheita do milho e do algodão. Gamon et alii (1992) estudaram as variações na eficiência fotossintética, ao longo do dia, utilizando o índice de vegetação. Estes trabalhos foram importantes para demonstrar a alta relação entre o índice e a atividade fotossintética da vegetação. Mais recentemente, Goward 
\& Huemmrich (1992) relacionaram os índices vegetativos com a radiação fotossinteticamente ativa absorvida pela cobertura vegetal, ao longo do dia. Para modelar a relação, o IVDN foi testado com variáveis, como: ângulo de incidência da radiação solar, ângulo de visada do sensor, índice de área foliar, ângulo da folha, propriedades ópticas da folha, tipo de substrato de fundo e outros fatores. Pinter Jr (1993) relacionou os valores de radiação fotossinteticamente ativa medido em campo com os valores do IVDN para áreas de cultivo de alfafa. Estes trabalhos mostraram que o IVDN está muito relacionado com a radiação fotossinteticamente ativa absorvida pela folha, e com a fitomassa verde da vegetação.

No trabalho recente de Gamon et alii (1995), o IVDN foi utilizado como indicador da estrutura do dossel, da luz absorvida, e da atividade fotossintética para três tipos fisionômicos de vegetação, natural da Califórnia e com diferentes densidade de cobertura vegetal. O IVDN teve uma relação quase linear com a radiação absorvida pelas folhas em todas as densidades de cobertura vegetal. $\mathrm{O}$ índice foi indicador sensitivo da estrutura do dossel e do conteúdo químico das folhas (fitomassa verde, índice de área foliar verde, quantidade de clorofila na folha e quantidade de nitrogênio).

Cyr et alii (1995) utilizaram o IVDN como indicador da densidade da cobertura vegetal de áreas de cultivo. $\mathrm{O}$ índice foi calculado com imagens SPOT para selecionar os tipos de cobertura do solo e, utilizando outras informações relacionadas ao solo construíram um modelo de previsão da erosão por água pluvial.

Ricotta et alii (1996) utilizaram o IVDN como indicador da densidade da cobertura vegetal, em área central da Itália. A imagem IVDN produzida à partir de imagens Landsat TM foi aplicada a um descritor textural de imagens para a classificação dos tipos de cobertura vegetal.

Outro tipo de aplicação do IVDN é o estudo temporal de mudanças globais. Fung \& Tucker (1986) mostraram que o IVDN vem sendo utilizado como meio de acompanhar as atividades da biosfera terrestre em escala global. Geralmente são utilizadas imagens NOAA-AVHRR com alta freqüência temporal e baixa resolução espacial. Shimabukuro et alii (1997) utilizou o IVDN a partir de imagens NOAAAVHRR, e frações de imagens do solo, do sombreamento e da vegetação para 
localizar os tipos de cobertura vegetal no estado de São Paulo. Os resultados obtidos para a vegetação foram comparados com o mapa de vegetação do estado de São Paulo produzido a partir de imagens Landsat (Kronka et alii, 1993), e apresentaram boa relação com este mapa.

No Brasil, em particular nos estudos do cerrado, Bitencourt-Pereira (1986) e Santos (1988) fizeram uma calibração do índice de vegetação, respectivamente, com o campo cerrado e com o cerrado senso estrito do planalto central. O primeiro autor relacionou fitomassa verde com a assinatura espectral obtida pelo MSS-Landsat e com radiometria de campo, e encontrou coeficientes de correlação linear (0,94 e 0,96 respectivamente). O segundo autor relacionou fitomassa de cerrado senso estrito com a assinatura espectral obtida pelo Landsat TM, encontrando também resultados satisfatórios. Contudo nenhum dos autores analisou, do ponto de vista espectral, as variações fenológicas que o cerrado apresenta.

O comitê de fenologia do Programa Internacional de Biologia (PIB) dos Estados Unidos sugeriu a seguinte definição para fenologia: "é estudo da frequiência temporal de repetição de eventos biológicos, das causas bióticas e abióticas relacionadas com a freqüência temporal de repetição destes eventos, e a relação entre as fases de espécies iguais ou diferentes" (Lieth, 1974). Os eventos fenológicos passíveis de observação com sensores remotos orbitais são a floração, a deciduidade e a morte de um conjunto de indivíduos numa paisagem, e estão relacionados à abscisão e senescência das folhas ou ao aparecimento de flores.

Morain (1974) ressaltou a importância da análise fenológica na ocasião da classificação das imagens, pois considerou que a vegetação só pode ser mapeada se considerarmos que os valores da imagem estão representando um espaço e um tempo. O trabalho ressalta que um dos problemas a serem considerados na análise fenológica por meio de sensores remotos orbitais é que aqueles que possuem alta resolução radiométrica têm baixa resolução temporal (inclusive em decorrência da cobertura de nuvens).

Tucker et alii (1985) realizaram a classificação dos tipos de cobertura vegetal (quanto às variações fisionômicas da vegetação) no continente Africano, utilizando imagens "Advanced Very High Resolution Radiometer" (AVHRR) do satélite 
National Oceanic Atmospheric Administrator (NOAA). Os autores mostraram, para cada formação vegetal, que existe alta relação do clima regional com a variação anual do IVDN.

Millington et alii (1992) mapearam florestas e savanas na África utilizando imagens AVHRR-NOAA e IVDN. Foi observada a fenologia ao longo do ano. Na escala continental, foi encontrada grande relação da produtividade de biomassa verde e a fenologia com o IVDN; o índice foi correlacionado com o regime de chuvas.

França (1994) realizou um estudo fenológico no cerrado, que ocorre no Parque Nacional de Emas - GO, na região do Brasil central. Foi observada a fenologia de áreas com predomínio das fisionomias de campo limpo e campo sujo de cerrado, com o IVDN obtido a partir de imagens digitais AVHRR-NOAA. Neste trabalho, o IVDN também foi relacionado com o regime de chuvas (fig. 2.1.2).

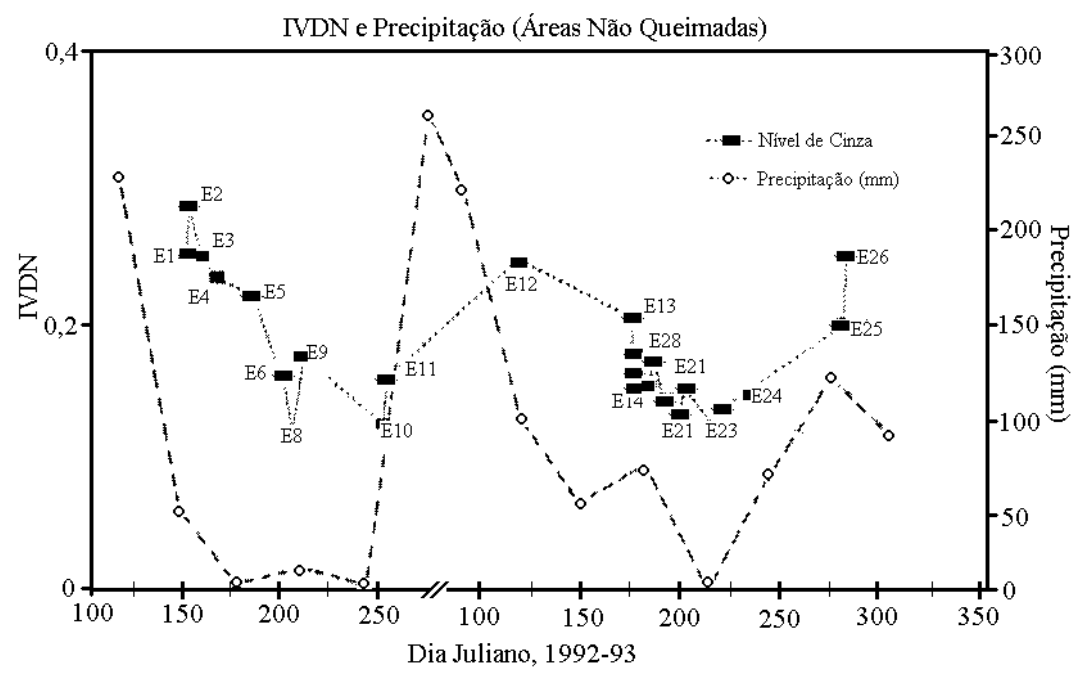

Figura 2.1.2 - Variação anual (92-93) do IVDN no campo cerrado do Parque Nacional de Emas - GO e da precipitação no mesmo período. Fonte: França (1994).

Anderson et alii (1993) utilizaram os IVDNs derivados do Landsat Thematic Mapper para fazer a estimativa de biomassa, estudando campos abertos de zona semidesértica. Neste trabalho é apontada a importância da consideração da fenologia da vegetação. Foram utilizadas três datas para o IVDN das imagens e para a coletas de material em campo (biomassa verde). O autor ainda ressaltou a importância da reflectância do tipo de solo de fundo, embutidas no IVDN. Salienta que as variações 
anuais nas condições atmosféricas, o ângulo de elevação solar, e a cobertura vegetal contribuem para os valores de IVDN.

Curran et alii (1992) realizaram a estimativa sazonal de Índice de Área Foliar em pinus com Landsat TM, fizeram regressões utilizando o IVDN e Índice de Área Foliar derivado de Biomassa coletada em campo em três datas. O trabalho mostra o grande potencial das Imagens Landsat TM para a análise da dinâmica do dossel ao longo do ano.

Qi et alii (1993) realizaram análise do IVDN com imagens multitemporais do satélite SPOT, considerando as condições do solo e do ângulo de visada. O estudo aponta que o índice é fortemente influenciado pelo ângulo de visada e anisotropia da superfície e, pouco pela variação atmosférica.

A análise espectral permite obter informações dos alvos da superfície terrestre, porém é importante relacioná-la à resolução espacial do sensor à bordo do satélite com o tamanho do alvo de interesse. Os alvos precisam ter, no mínimo, o tamanho de um ponto na imagem, no caso do Landsat TM de $30 \mathrm{~m}$ por $30 \mathrm{~m}$.

As formas fitofisionômicas mais abertas (formas campestres e arbustivas) ocorrem junto com áreas de solo nu. Usualmente, neste tipo de vegetação - um quadrado de 30m por 30m (tamanho de uma cela ou "pixel" na imagem) - ocorrem pequenas porções de solo exposto em meio ao dossel da vegetação. Esta configuração espacial gera uma resposta espectral, para a correspondente cela da imagem, da vegetação verde misturada com outros alvos de menor participação, como as respostas espectrais: do solo nu, dos galhos, das folhas secas e da sombra causada pela rugosidade do dossel.

Ringrose et alii (1989), com imagens Landsat MSS e SPOT, estudaram a participação da reflectância do solo em savana arbórea africana sujeita a período de estiagem. Os autores apontaram a importância de considerar o tipo de solo, principalmente em áreas com menor cobertura vegetal. Os autores sugerem que os índices de vegetação não podem ser aplicados à savana arbórea porque sofrem um período de estiagem muito longo, o que ocasiona um baixo espalhamento anormal do infravermelho próximo. Apontaram também, que solos escuros podem interferir na resposta espectral da vegetação. 
Roberts et alii (1993) procuraram mensurar e modelar (fração de participação) o grau de influência da resposta espectral de outros alvos de fundo nos valores espectrais da vegetação. Os autores notaram que, além do solo e sombra (do dossel rugoso), existe participação da vegetação não fotossinteticamente ativa, que compreende: folhas secas (necromassa graminóide, folhas senescentes e persistentes e serapilheira), galhos, troncos e madeira em decomposição.

Huete et alii (1985) analisaram as diferentes respostas espectrais do dossel de diferentes graus de cobertura e sobre diferentes tipos de solo, em área de plantio de algodão. Os resultados mostram que coberturas de $100 \%$ não sofrem influência do solo. À medida que diminui a cobertura vegetal ocorre aumento da reflectância do solo, que causa uma diminuição no IVDN característico da cobertura. Huete (1986) buscou analisar separadamente, através de modelagem matemática, a participação da vegetação e do solo em diferentes condições de cobertura vegetal e tipos de solo.

O relevo também pode influenciar a resposta espectral esperada para a vegetação. Em relevos muito acidentados pode ocorrer grande variação na radiação incidente em decorrência de reflexões da radiação. Assim, a posição do Sol no momento da aquisição das imagens e a orientação das vertentes ${ }^{8}$ são importantes, pois podem influenciar na resposta espectral medida à distância.

Sader et alii (1989) relacionaram o IVDN com a biomassa e estádio sucessional de florestas tropicais. As classes de declividade ${ }^{7}$, orientação de vertentes ${ }^{8}$ e altitude foram comparadas com o IVDN. O índice é influenciado pela orientação de vertentes e declividade e os dados do satélite Landsat TM são fortemente influenciados pela topografia. Os dados mostraram que o IVDN é bom indicador dos estádios iniciais de sucessão e ruim para estádios avançados (florestas maduras). Os autores recomendam a não utilização do IVDN para a estimativa de biomassa e estoque total de carbono em florestas tropicais úmidas.

Proy et alii (1989) avaliaram os efeitos da topografia nos dados obtidos por satélites. A área de estudo foi uma região altamente acidentada dos Pirineus. Os autores observaram que a radiação medida pelo satélite Landsat TM é fortemente influenciada pela topografia. Nestas regiões, algumas partes da imagem com o mesmo tipo de cobertura podem ter diferentes valores de radiação. Esta variação corresponde 
às diferenças do terreno, como áreas que: a-) não recebem radiação direta, b-) que recebem radiação direta, c-) que recebem a radiação indireta parcialmente, d-) que recebem a radiação refletida por uma superfície próxima. No mesmo trabalho, foram apresentados modelos de correção dos valores de radiação medida pelo satélite.

As condições atmosféricas podem modificar-se muito, ao longo do tempo, em decorrência da presença de partículas e gotículas em suspensão ou vapor de água na atmosfera. Nas regiões de latitudes altas, a posição do Sol modifica-se em relação à superfície terrestre. Existem alguns modelos matemáticos que buscam minimizar os efeitos causados pelas mudanças de iluminação e de condições atmosféricas. Há métodos absolutos de calibração, que consistem na conversão de número digital das imagens em radiância ou reflectância no satélite, ou exoatmosférica (Robinove, 1982; Markham \& Barker, 1986). Existem os métodos relativos de calibração, como o de correção dos dados, baseado apenas em parâmetros da imagem, como por exemplo, a técnica de subtração do objeto escuro (Chaves Jr., 1989).

\subsection{Geoprocessamento}

O Sistema de Informações Geográficas (SIG) é um sistema assistido por computador para a importação, armazenamento, análise e apresentação de dados geográficos. Existem muitos programas homônimos, que se diferenciam quanto aos caminhos e operações que realizam (Eastman, 1995).

O potencial de integração das informações derivadas dos dados de sensoriamento remoto no SIG foi identificado há, aproximadamente, três décadas atrás (Garrison et alii, 1965 apud Colwell, 1983). Nos anos subseqüentes, os programas de SIG desenvolvolveram-se no que se refere à entrada de dados de mapas temáticos e cartográficos e à integração destes com dados remotamente sensoriados. O processamento de imagens digitais consiste na utilização de algoritmos que transformam os valores de uma (ou mais) imagem gerando uma nova imagem (Crosta, 1993). Quando o processamento se dá com imagens referenciadas com coordenadas da superfície terrestre, como as imagens de satélite, chama-se 
geoprocessamento. De qualquer forma, a principal característica do SIG é a combinação de grande quantidade de dados geo-referenciados. Para realizar esta tarefa, associado ao SIG, foram desenvolvidos sistemas para entrada de dados de diversas fontes, como mesas digitalizadoras (dados temáticos e cartográficos), o GPS - Global Positioning System (dados de campo) e módulos de processamento digital de imagens (dados de sensores remotos). O crescente desenvolvimento da informática, e a disseminação dos computadores pessoais, vem tornando o SIG uma ferramenta cada vez mais importante para os estudos do meio ambiente.

Para compreender melhor o geoprocessamento e os SIG, é necessário o esclarecimento de alguns conceitos. O geoprocessamento compreende as tecnologias que possibilitam a análise geográfica computadorizada, a partir de informações no formato vetorial e matricial. ${ }^{12}$ Alguns SIGs são apenas matriciais, outros apenas vetoriais e outros vetoriais e matriciais. Os mais comuns são os SIGs matriciais, em virtude da facilidade de processamento de matrizes em operações matemáticas, mas que também fazem alguns processamentos vetoriais, como é o caso do programa IDRISI.

As variáveis analisadas pelo SIG são identificadas em campo e disponibilizadas de duas maneiras: formas geométricas, demarcadas em uma base cartográfica ou delimitada por GPS; e as classes obtidas por sensoriamento remoto.

Para tornar digital as formas geométricas, disponíveis em mapas temáticos ou cartográficos (que podem ser indicadoras de informações ecológicas), utiliza-se uma mesa digitalizadora.

Para dar padrão cartográfico aos dados obtidos por sensoriamento remoto é preciso geo-referenciar a imagem "escaneada", seja por satélite ou por scanner ${ }^{4}$ de mesa, na mesma base cartográfica de informação de campo (através da mapas ou por GPS).

Os principais elementos da geometria plana utilizados como entidades básicas do SIG, são: pontos, linhas ou arcos, polígonos e o plano. Com estes elementos é possível representar em 2 dimensões qualquer objeto ou forma da superfície da terra. Para representação geográfica de qualquer objeto da superfície terrestre é necessário um sistema de coordenadas para posicioná-lo. Assim, alguns parâmetros do meio 
ambiente podem ser representados por coordenadas cartesianas $\mathrm{X}$ e $\mathrm{Y}$ num plano bidimensional, armazenando-se na forma vetorial. Para facilitar a combinação das diferentes informações, estes dados são convertidos para a forma matricial.

O desenvolvimento do SIG possibilitou aos ecólogos a integração e manipulação de dados de diversas fontes e a construção de modelos de processos que modificam-se no espaço e no tempo (Rosa, 1992). Atualmente, muitos trabalhos têm utilizado esta técnica na produção de planos de manejo de recursos. Steiner (1991) utilizou o SIG para planejamento da paisagem. Para tal, foram colocadas diversas informações do ambiente (situação passada, atual) que permitiram fazer previsões de crescimento populacional e possíveis consequiências ao meio ambiente. Posteriormente, outros autores como Loh \& Rykiel Jr (1992) e Xiang (1993) desenvolveram modelos mais sofisticados para análise de mudanças ambientais e previsão de danos. Utilizando as técnicas de SIG, diversos trabalhos começaram a ser produzidos para conhecer padrões e processos ecológicos de uma região. Moore et alii (1991), na Austrália, utilizaram o SIG para produção de um modelo de previsão da distribuição da vegetação; a partir de dados de campo sobre a vegetação e do meio físico (base cartográfica), o modelo produziu um mapa da distribuição das comunidades vegetais. Lees \& Ritman (1991), estudando a mesma região na Austrália, aprimoraram o modelo utilizando regras de decisão e informações de imagens de satélite para aprimorar de mapeamento da vegetação. Ball (1994) faz uma boa revisão de trabalhos de modelagem em ecologia utilizando o SIG. Nos trabalhos de Welch \& Remillard (1992) e Welch et alii (1995) foi realizada a integração de diversas fontes de informação para a produção de uma base de dados geográficos de áreas de conservação, para auxiliar o manejo das áreas por órgãos de proteção ambiental.

As informações obtidas em campo podem ser analisadas e relacionadas às informações das imagens por meio de um sistema de posicionamento geográfico, conhecido popularmente por GPS, do inglês Global Positioning System.

O GPS foi projetado para fornecer a posição instantânea de um objeto em qualquer parte da superfície do globo terrestre. Através de sistema de referência tridimensional, baseado em sinais de satélites ao redor da terra, fornece as 
coordenadas geográficas e a altitude de objetos na superfície do globo ou próximos dele. Os sinais recebidos pelo GPS também incluem o tempo da terra, que permite conhecer a velocidade do objeto em relação a superfície.

Segundo Blitzkow (1995) o GPS vem experimentado uma revolução em termos de receptores, precisão e diferentes aplicações e deverá, no futuro, atender plenamente à navegação em geral.

O GPS consiste num aparelho dotado de uma antena que capta os sinais de satélites a $20.000 \mathrm{~km}$ de altura (sempre existem pelo menos 4 satélites disponíveis no céu). O sinal é processado e analisado por um programa interno do aparelho, que compara o sinal com os valores de referência armazenados na memória interna, para, assim, mostrar o valor das coordenadas no visor . Senus \& Hill (1981) fazem uma boa descrição do funcionamento do aparelho.

Além destes processamentos automáticos, os aparelhos modernos permitem realizar a busca de pontos previamente implantados na memória do sistema, cálculo de distância e tempo de chegada previstos, mostrar os pontos na forma gráfica (como um mapa), bússola, construção de rotas e armazenar instantaneamente pontos marcados em campo.

O recente desenvolvimento do sistema para pequenas unidades portáteis e com preços cada vez mais competitivos, tornaram esta ferramenta disponível aos ecólogos. Welch \& Remillard (1992) utilizaram o GPS para entrar com dados de campo de elevação num SIG, para ajustar um mapa de elevação do terreno. Em outro trabalho de Welch et alii (1995), o GPS foi utilizado em campo para checar o posicionamento das classes do mapa da distribuição vegetação natural em Parques Nacionais e Reservas do sul da Florida. 


\subsection{Fisionomias do cerrado}

O termo cerrado tem conotação regional no Brasil, enquanto o termo savana é mais geral e aplicado a vários tipos de vegetação no mundo. Em ambos os casos, a vegetação, em linhas gerais, ocorre nos trópicos, com forte influência sazonal e de composição mista graminóide e lenhosa.

Azevedo (1972) caracterizou o cerrado como formação complexa, que ocorrem na áreas de planalto do interior do país, na faixa tropical com predomínio do clima quente e úmido, com chuvas de verão e estação seca bem marcada, lençóis d' água profundos e solos antigos (deficiências minerais e más condições de drenagem). São características freqüentes associadas a esta vegetação: geralmente árvores pequenas e com galhos e troncos retorcidos, geralmente apresentam a casca espessa e protegida por uma camada de cortiça, e algumas espécies apresentam alto grau de escleromorfismo (folhas coriáceas). Nesta descrição, Azevedo fez referência ao problema da terminologia empregada para os subtipos de cerrado. Segundo o autor, estes variam de acordo com o maior ou menor porte e espaçamento das árvores ou segundo a abundância ou não destas e dos arbustos. $\mathrm{O}$ cerradão tem a aparência semelhante a de outras formações florestais, mas conserva a composição florística do cerrado e os campos sujos ou campos cerrados são as formas mais diluídas. Este último termo pode levar a interpretação errônea de categoria de campos.

Segundo a revisão de literatura de Eiten (1972) sobre o cerrado, os geógrafos brasileiros distinguem 4 tipos estruturais de cerrado, sumariamente descritos abaixo:

1. cerradão - Formas arbóreas de médias a altas, com dossel fechado ou semi aberto.

2. cerrado senso estrito - a.) Formas arbóreas podem formar dossel fechado ou semi-aberto porém sem ultrapassar 7 metros de altura. b.) Formas arbustivas fechadas ou semi-abertas (com dossel geralmente inferior a 3 metros de altura). c.) Arbustivo fechado ou semi aberto, misturado com árvores esparsas de várias alturas e abaixo uma camada de arbustos de variadas alturas, em conjunto com um dossel muito rugoso. 
3. campo cerrado - Inclui várias formas com a cobertura de plantas lenhosas geralmente muito esparsas. a. Formas arbustivas, b. Formas arbóreas baixas e abertas, c. Fisionomia de savana típica, árvores médias ou baixas, ou arbustos, ou ambos misturados, sobre uma camada contínua ou ligeiramente aberta de gramíneas, ervas e subarbustos.

4. campo limpo - Paisagem com predomínio de gramíneas, com ausência de árvores.

Coutinho (1978) apontou em seu trabalho o problema da diversidade de termos e conceitos do cerrado em nível fisionômico e florístico, realizando uma significativa revisão sobre o assunto. Neste trabalho é apresentado o "conceito floresta-ecótono-campo", que considera o cerrado um complexo de formas, que vão desde o campo limpo (formação campestre) até o cerradão (formação florestal). Representando as formas intermediárias estão o campo sujo, o campo cerrado e o cerrado senso estrito. As formas propostas por Coutinho claramente refletem as condições ecológicas locais, tais como: condições físicas ou químicas do solo, geomorfologia, topografia, freqüência de queimadas, pastoreio, etc.

Muitos estudos foram realizados nos domínios do cerrado, procurando caracterizar a vegetação florística e fisionomicamente, além de reconhecer os fatores ambientais associados à sua ocorrência (Ferri, 1971; Rizzini, 1971; Goodland \& Ferri, 1979). Outros trabalhos também buscaram caracterizar os subtipos de cerrado (Coutinho, 1978), considerando aspectos ecológicos com base em diferentes atributos da vegetação e as características do meio físico obtidos em campo (Nogueira-Neto, 1991).

Durigan et alii (1987) estudou as fisionomias de cerrado para conhecer o padrão temporal de adensamento da vegetação, utilizando fotografias aéreas, na região de Assis-SP. Neste trabalho existe uma boa revisão sobre a evolução das definições de cada fisionomia de cerrado.

O Instituto Brasileiro de Geografia e Estatística - IBGE (1991) ressaltou o problema de unificação de terminologias no Brasil, referindo-se ao mapeamento da vegetação brasileira no contexto mundial, e que tal diversidade de termos relaciona-se 
às escalas de trabalho utilizadas. No referido trabalho é proposta a utilização do sistema de classificação em escalas crescentes, desde o regional (1:10.000.000) até o detalhado (1:25.000), baseado no sistema de classificação Fisionômico-Ecológico, segundo Ellenberg \& Mueller-Dombois (1965/6). Neste sistema, a savana brasileira (cerrado) é subdividida em: florestada, arborizada, parque, gramineo-lenhosa (sendo as três últimas subdivididas em: com ou sem a presença de mata de galeria). Cada um dos subtipos de cerrado foi descrito fisionomicamente, floristicamente e da distribuição relativa das formas de vida proposta por Raunkier (1934) e adaptada às condições brasileiras.

Batalha (1997) estudou a estrutura das fisionomias de vegetação na gleba Péde-Gigante, e observou que a biomassa estimada pelo volume cilíndrico total aumentou do campo cerrado à floresta estacional semidecídua, com valores intermediários no cerrado senso estrito e no cerradão. Analisou, também, a composição florística e a similaridade das fisionomias, e notou que existe similaridade florística entre as fisionomias de cerrado senso lato.

\section{Materiais e Métodos de Pesquisa}

A seguir serão descritos os materiais utilizados na pesquisa, bem como o método adotado para a sua realização. No primeiro item será apontado o objeto de estudo, a localização e principais características da amostra de cerrado escolhida para realização do trabalho. No item seguinte serão apresentados os instrumentos utilizados nas atividades de campo e de laboratório. No item aquisição e registro dos dados apresentam-se os métodos utilizados para obtenção dos dados brutos no campo ou no laboratório. O item estudo piloto apresenta o trabalho preliminar que serviu para a identificação e a localização dos tipos fisionômicos de cerrado na área amostrada. $\mathrm{O}$ último item refere-se aos métodos específicos adotados para análise dos dados brutos obtidos em campo e os gerados em laboratório. 


\subsection{Objeto de Estudo}

O objeto de estudo deste trabalho foi o gradiente de morfotipos de cerrado existentes na gleba Pé-de-Gigante, uma unidade de conservação situada no Município de Santa Rita do Passa Quatro, no estado de São Paulo.

Inicialmente, a reserva estava anexada ao Parque Estadual de Vassununga, criado pelo Governo do Estado de São Paulo, através do Decreto No. 52.546 de 26/10/1970, para preservar os remanescentes de florestas estacionais semideciduais que abrigam espécimes de jequitibá vermelho (4 glebas), e a formação geológica de interesse turístico (depressão na forma de pé gigante), com vegetação do tipo cerrado, que abriga as cabeceiras do Ribeirão Paulicéia (Bertoni et alii, 1986).

Posteriormente, a reserva de cerrado Pé-de-Gigante foi transformada em unidade de conservação do tipo “Área de Relevante Interesse Ecológico" - ARIE (administração federal) através da resolução CONAMA No. 18 de 07/12/1989 e Decreto No. 99.275 (Da Silva \& Fornasari-Filho, 1992). Em 1996 foi firmado um convênio entre a Universidade de São Paulo e a Secretaria do Meio Ambiente, através do Instituto Florestal - conforme autorização do governador nos autos do processo SMA No. 41.573/96 - em que a unidade de conservação voltou a ser gleba Pé-deGigante do Parque Estadual de Vassununga. Firmou-se o convênio do Instituto Florestal com a Universidade de São Paulo objetivando a realização de atividades de ensino e pesquisa no Parque Estadual de Vassununga, especificamente na gleba Péde-Gigante.

A gleba Pé-de-Gigante tem área aproximada de 1225 ha, e suas coordenadas geográficas aproximam-se de $21^{\circ} 37^{\prime} 30^{\prime \prime}$ Sul e $47^{\circ} 37^{\prime} 30^{\prime \prime}$ Oeste. Está situada sobre a Serra de Santa Rita, em altitudes variando de 590m a 740m, entre os quilômetros 254,5 e 258,5 da Rodovia Anhanguera, SP-330. A localização da área de estudo está ilustrada na figura 3.1.1, indicando a posição em três níveis: nacional, estadual e regional. O relevo na área de estudo é pouco acidentado, com predomínio de terrenos planos. Nas encostas da bacia de drenagem existem locais com maior inclinação. 


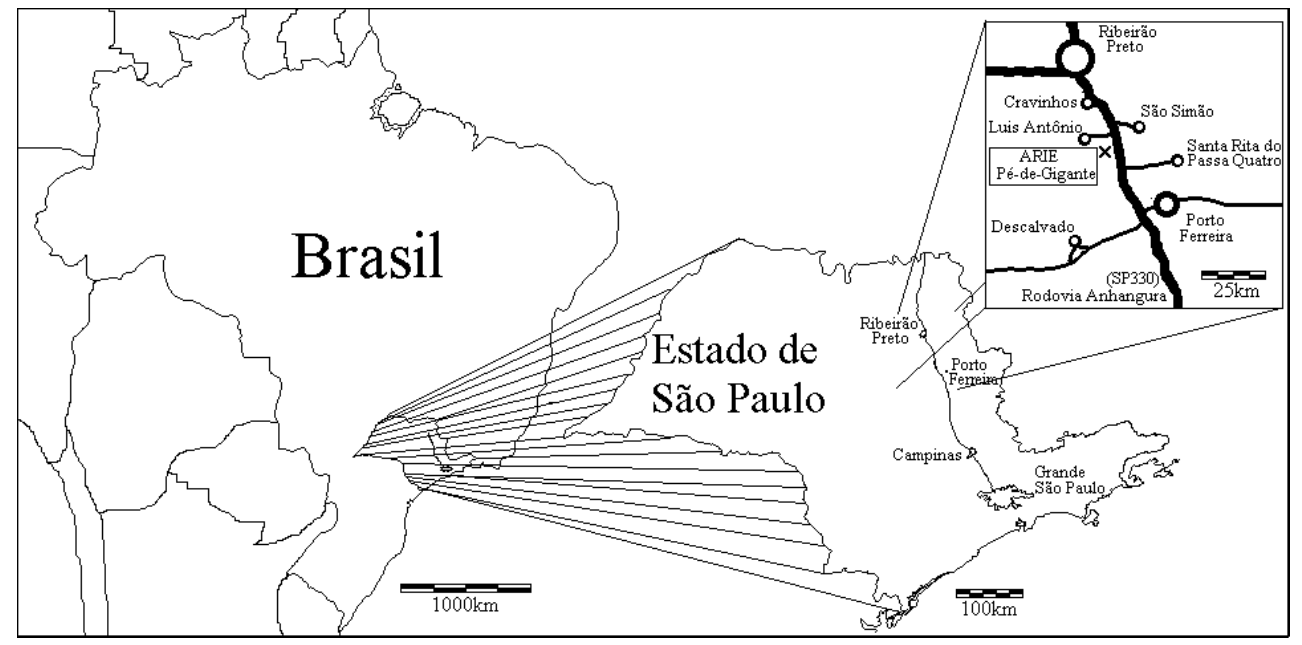

Figura 3.1.1 - Localização da área de estudo no contexto nacional, estadual e regional.

A geologia da região do município de Santa Rita do Passa Quatro foi estudado por Massoli (1981), em escala de 1:50.000. Do ponto de vista geomorfológico, predominam as Cuestas Basálticas, constituídas de arenitos das formações Botucatu, Pirambóia e Santa Rita, e pelos basaltos da formação Serra Geral. A rede de drenagem do Ribeirão Paulicéia escavou predominantemente os arenitos das formações Botucatu e Pirambóia, formando vales profundos próximos às cabeceiras. Os arenitos originam solos variando de moderados a pobres, nas porções de altitudes médias; e de pobres à muito pobres, nas partes baixas dessas formações. Tais solos estão constantemente sujeitos à erosão e aparecimento de voçorocas. Nas partes mais baixas ocorrem depósitos aluviais, com predomínio de areia. Na formação Botucatu pode ocorrer arenito conglomerático, evidenciando a deposição de rios temporários de bordo de deserto (Mesozóico). Na parte sul da gleba Pé-de-Gigante podem ocorrer solos com participação da formação Serra Geral, formada por derrames basálticos originados por vulcanismo de fissuras. A meteorização das rochas ígneas formam, em grande parte, solos de excelente qualidade agrícola.

A figura 3.1.2. apresenta o climadiagrama da região de Santa Rita do Passa Quatro. Estão representados o regime das chuvas e a curva anual de temperatura. O clima possui um período de diminuição das chuvas e queda da temperatura média nos meses de julho a agosto. Este período é caracterizado como estiagem de inverno. Existe um aumento das chuvas nos meses de dezembro a fevereiro, associado à alta 
temperatura média, o que caracteriza o verão chuvoso. Essas condições do clima da região correspondem ao clima Cwa, segundo o sistema climático de Koeppen (1948).

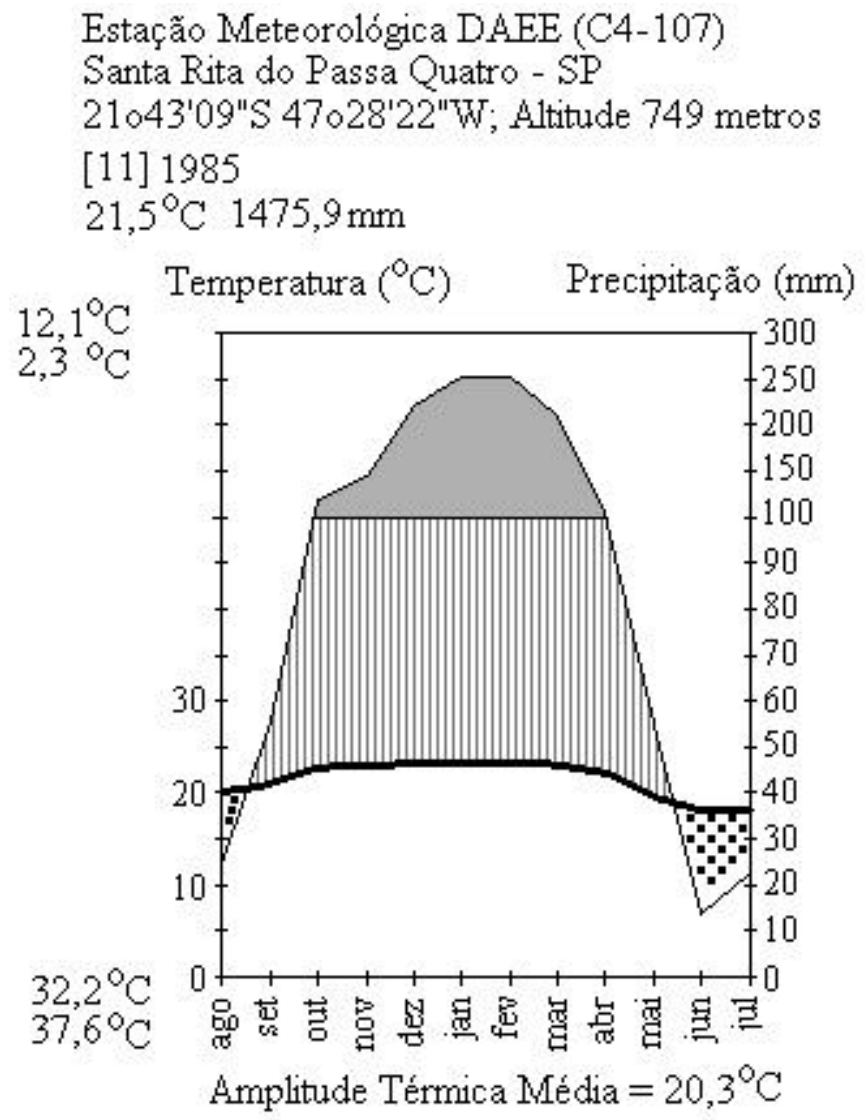

Figura 3.1.2 - Climadiagrama segundo o método de Walter (1955 apud. Walter et alii 1985), estação meteorológica de Santa Rita do Passa Quatro (C4-107, DAEE).

Considerando o local estudado em relação à distribuição dos cerrados brasileiros, a gleba Pé-de-Gigante corresponde às pequenas áreas disjuntas do cerrado meridional (Eiten, 1972).

A gleba Pé-de-Gigante é constituída por um gradiente de fisionomias de cerrado, partindo de formas campestres até florestais. Esta configuração de gradiente fisionômico foi apresentada por Coutinho (1978) como conceito de cerrado, formações que vão de campo limpo (campo) a cerradão (floresta), passando pelos ecótonos de campo sujo, campo cerrado, cerrado senso estrito (formações intermediárias). 
A área de estudo está circundada por silvicultura (eucaliptos) e agricultura (citrus e cana). Todas as formas de uso da terra são temporárias e de moderado impacto ao ambiente, e com possíveis interferências aos elementos do meio biótico da reserva.

O trabalho foi realizado numa área de proteção ambiental com cobertura vegetal de formação do cerrado com outras formações, localizada na depressão da bacia de drenagem do Ribeirão Paulicéia. Com esta configuração ambiental ocorrem diferentes formas xeromórficas (de florestais a campestres), que em grande parte são decorrentes das mudanças nas variáveis dos fatores do ambiente físico (condições edáficas, disponibilidade hídrica, solo, e outros). Além de vários morfotipos, a existência de um período de seca bem definido na região acarreta variações fenológicas passíveis de serem detectadas por sensores remotos, uma vez que altera a composição de folhas verdes presentes em decorrência da senescência e abscisão foliar (fig. 3.1.3). 


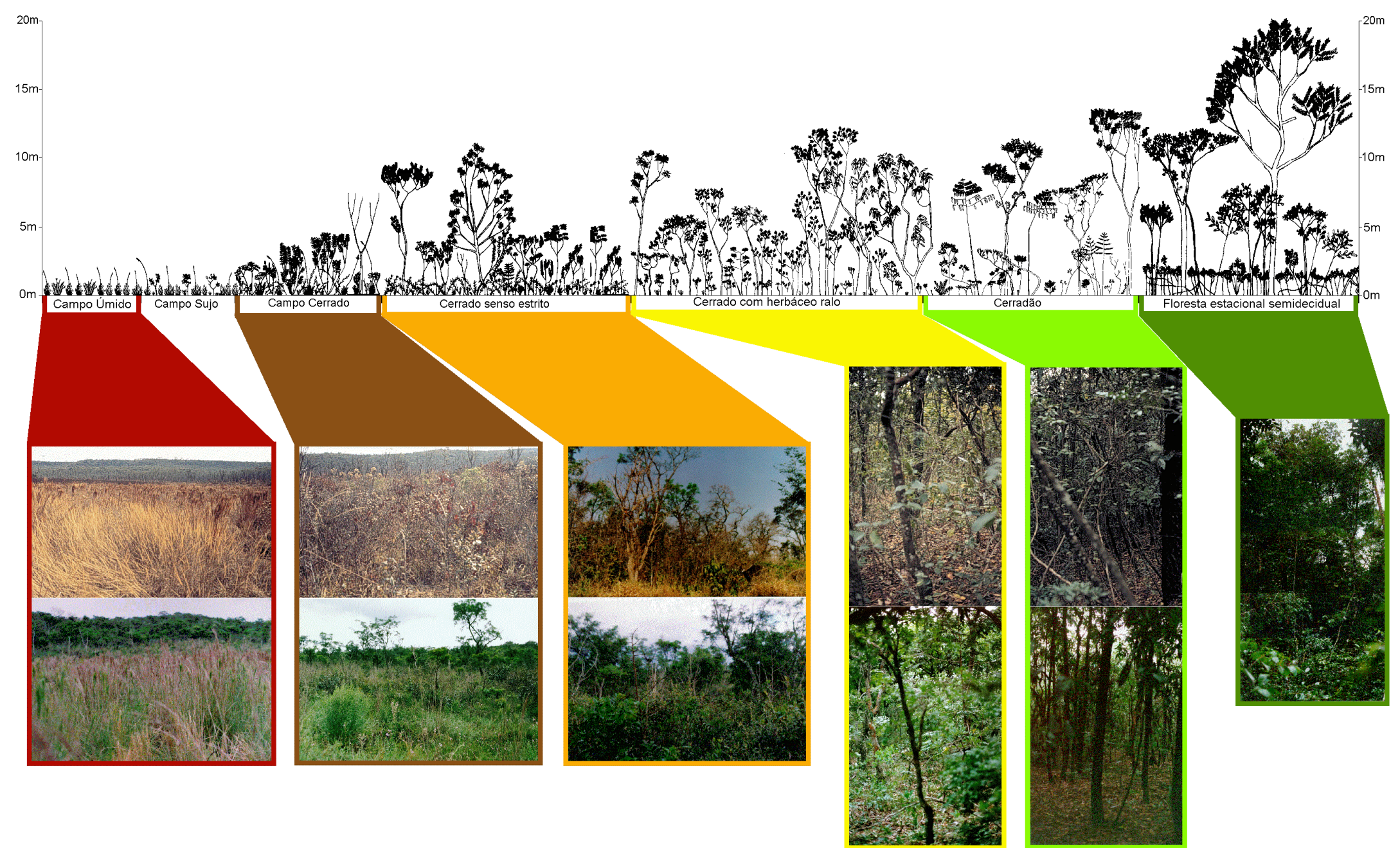

Figura 3.1.3 - Gradiente fisionônico dos morfotipos de cerrado senso lato da gleba Pé-de-Gigante e as variações decorrentes da sazonalidade (período de estiagem e de máxima precipitação). Fonte: Bitencourt \& Mesquita Jr (em impressão). 


\subsection{Instrumentação}

As atividades de gabinete foram realizadas no Laboratório de Análise da Paisagem e Conservação LEPaC do Departamento de Ecologia Geral do Instituto de Biociências - USP. Os equipamentos utilizados foram um computador pessoal com processador Pentium $133 \mathrm{MHz}$, uma mesa digitalizadora marca Digigraf, uma impressora modelo Deskjet 680 da marca Heweltt Packard e um Scanner ${ }^{4}$ modelo ScanJet IIc da marca Heweltt Packard. Os programas de computador IDRISI e Tosca, da Clark University e o SITIM do Instituto Nacional de Pesquisas Espaciais (INPE) foram utilizados para o geoprocessamento das imagens. $\mathrm{O}$ acabamento final e a impressão das imagens, foram feitas com os programas "Photo Styler 2.0" e "Word 6.0 ".

O programa SITIM do INPE foi utilizado para visualização da cena e seleção da área de estudo na imagem a partir dos dados armazenados em fita "streamer" ${ }^{2}$. As áreas selecionadas foram exportadas para o IDRISI. Os dados armazenados em CD$\mathrm{ROM}^{1}$ foram selecionados com o programa fornecido pelo INPE e transferidos para o IDRISI. As imagem no formato $\mathrm{TIFF}^{3}$ foram selecionadas com o programa "Photo Styler 2.0". O geoprocessamento foi realizado com o programa IDRISI, que proporcionou a aplicação de diversas funções: o processamento de imagens multispectrais; geração de imagens temáticas; construção do modelo digital do terreno (MDT); análise de superfícies; operações booleanas entre duas ou mais imagens, registro da referência geográfica das imagens, extração e operações aritméticas com os valores da matriz de pontos da imagem; e entrada de dados de campo geograficamente registrados com o GPS.

Nas atividades de campo foram utilizados os seguintes equipamentos: um GPS modelo "GPS 45" da marca "Garmin" e uma máquina fotográfica da marca "Pentax" modelo "SP" com lente de $55 \mathrm{~mm}$ de distância focal. E outros materiais foram importantes no registro de dados em campo, como: estacas e barbante, trenas de $10 \mathrm{~m}$ e 50m (modelo/marca: Stanley); Telêmetro (modelo/marca: Range 120); Prensa , Papelão e Jornal; Tesoura de Poda; Chave de Identificação (Mantovani et alii, 1985); 
Bússola; Altímetro (Altímetro/Barômetro Analógico - Thommen 0-6000m, Suíça); Luxímetro/Fotômetro (Panlux Eletronic 2, Gossen, Alemanha); e material de consumo para anotações.

\subsection{Aquisição e Registro dos Dados}

A aquisição dos dados brutos foi realizada em campo para a caracterização detalhada do objeto de estudo (registros de campo geo-referenciados), outros foram gerados no laboratório por meio de digitalização ou por processamento digital de imagens de satélite e alguns dados foram recuperados de outras fontes para comparação. Neste item será apresentado o meio de obtenção dos dados brutos.

\subsubsection{Consulta Bibliográfica}

A bibliografia utilizada neste trabalho foi recuperada nas bibliotecas do Instituto de Biociências, do Departamento de Geografia, do Instituto Oceanográfico e Instituto de Geofísica e Astronomia da Universidade de São Paulo (USP); dos Departamentos de Biologia e Geologia da Universidade Estadual de Campinas; do Instituto de Biociências da Universidade de Brasília; do Departamento de Geografia e Geologia e da Faculdade de Política e Ciências Ambientais do Universidade de Indiana (E.U.A.); e do Departamento de Geografia do Boston (E.U.A).

As bibliografias foram selecionadas por meio de fichas catalográficas ou através de pesquisa por meio de CD-ROM ${ }^{1}$ do "Biological Abstracts".

\subsubsection{As imagens de satélite}

As imagens de satélite no Brasil são distribuídas pelo Instituto Nacional de Pesquisas Espaciais (INPE). As imagens de 05 julho de 95, 22 de agosto de 95 e 29

\footnotetext{
${ }^{1} 1$ e 3 Glossário de termos na página 117
} 
de janeiro de 96 foram compradas com o financiamento do projeto de manejo da gleba (FAPESP proc. 95/0350-1). A imagem de 23 de julho de 96 foi fornecida pelo Departamento de Geografia da USP, e a imagem de 08 de junho de 1997 foi fornecida pela Secretaria Estadual de Meio Ambiente do Estado de São Paulo (SMA-SP).

O sistema utilizado foi Landsat TM, com resolução no terreno de 30 x 30 metros e resolução radiométrica ${ }^{11}$ de 8 bits e resolução espectral ${ }^{10}$ de 7 faixas. As

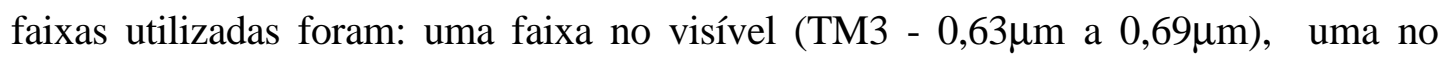
infravermelho próximo (TM4 - 0,76 $\mathrm{m}$ a $0,90 \mu \mathrm{m})$, e uma no infravermelho médio $(1,55 \mu \mathrm{m}$ a $1,75 \mu \mathrm{m})$.

As imagens de julho 95 e de agosto foram extraídas de fita magnética do tipo "streamer" 2 com a informação no formato INPE. As imagens restantes foram extraídas de CD-ROM ${ }^{1}$, sendo as de janeiro e junho no formato INPE e a de julho no formato $\mathrm{TIFF}^{3}$.

Todas as imagens são do quadrante com órbita 225 ponto 075 . Os ângulos de elevação solar foram de $34^{\circ}$ para a data de agosto de 95 , de $27^{\circ}$ para julho de 95 , de $45^{\circ}$ para janeiro de 96 , de $30^{\circ}$ para julho de 96 e de $32^{\circ}$ para junho de 97 .

\subsubsection{Dados Meteorológicos}

Os dados meteorológicos foram obtidos no Centro Tecnológico de Hidráulica do Departamento de Águas e Energia Elétrica (DAEE) do estado de São Paulo. Recuperadas as medidas realizadas na estação meteorológica de Santa Rita do Passa Quatro, do período de 1985 a 1997 para os dados mensais, e de 1995 a 1997 para os dados diários. Foram analisados os seguintes parâmetros meteorológicos:
a. Precipitação acumulada em milímetros.
b. Temperatura média em graus Celsius.
c. Temperatura mínima absoluta em graus Celsius.
d. Temperatura máxima absoluta em graus Celsius. 
e. Umidade Relativa Média em porcentagem de saturação de água no ar.

\subsubsection{Mapas temáticos}

Os mapas temáticos foram comprados no Instituto Brasileiro de Geografia e Estatística - IBGE, topografia 1:50.000 (IBGE, 1971), no Instituto de Geografia e Cartografia do Estado de São Paulo - IGC, topografia 1:10.000 (IGC, 1990a e 1990b), no Instituto de Geologia do Estado de São Paulo IG, geologia 1:100.00 (IG, 1986) e no Instituto Agronômico do Estado de São Paulo, pedologia 1:50.000 (EMBRAPA, 1982). Todos os mapas foram adquiridos em formato de papel, ou em cópias héliográficas (mapas topográficos do IGC).

Após a integração das informações dos mapas, foram gerados novos mapas derivados das informações digitalizadas. Foram produzidos o modelo digital do terreno $^{5}$ - MDT, o modelo digital de iluminação relativa ${ }^{6}$ do relevo, o mapa de declividade $^{7}$ e o mapa de orientação de vertentes.

\subsubsection{Dados de Campo}

\subsubsection{Diagramas de perfil}

Foram elaborados diagramas de perfil da vegetação (Mueller-Dombois, 1984) nas diferentes fisionomias de cerrado.Para cada fisionomia foi selecionada uma área amostral para inclusão dos indivíduos nos perfis (floresta estacional semidecidual de $25 \mathrm{~m} \times 2 \mathrm{~m}$, cerradão de $25 \mathrm{~m} \times 2 \mathrm{~m}$, cerrado com herbáceo ralo $15 \mathrm{~m} \times 2 \mathrm{~m}$, cerrado senso estrito de $10 \mathrm{~m} \times 2 \mathrm{~m}$, campo cerrado de $10 \mathrm{~m}$ x $2 \mathrm{~m}$ e campo limpo $2,5 \mathrm{~m} \times 1 \mathrm{~m}$ ). $\mathrm{Na}$ ocasião do registro foram medidos o perímetro das espécies arbóreas no nível do solo; feita a identificação da espécie (ou coleta do material); registrada a posição 
geográfica; estimada a altura e registrado o desenho da posição e forma das árvores em papel milimetrado.

As parcelas foram lançadas sempre com a base maior no sentido Leste - Oeste. Os locais foram selecionados em áreas características do tipo fisionômico. Estas áreas foram obtidas a partir da imagem de satélite classificada preliminarmente no estudo piloto (mapa preliminar de fisionomias). Neste mapa, foi escolhida a maior mancha para cada fisionomia. As coordenadas do centro da mancha foram utilizadas para localizar cada fisionomia.

\subsubsection{Fotografias verticais}

Foram registradas fotografias verticais da cobertura vegetal; a câmara fotográfica foi posicionada verticalmente no nível do solo. Foi registrada a diferença de contraste entre as regiões com cobertura vegetal e as partes com iluminação direta. Depois as fotografias foram digitalizadas em "scanner" e transformadas em imagens binárias: preto cobertura vegetal e branco sem cobertura (céu). Não é aconselhável utilizar estes valores de forma absoluta, pois podem existir distorções na área amostrada pela lente fotográfica (Carvalho, 1997), mas servem para fins comparativos.

\subsubsection{Fotografias da paisagem}

Foram registradas várias fotografias da paisagem e tomadas as posições geográficas. As fotografias, geralmente, foram panorâmicas ou como um perfil da vegetação. 


\subsubsection{Luminosidade}

Foi registrada a luminosidade relativa nas diferentes fisionomias; medida a iluminação em Lux acima da cobertura do dossel e no nível do solo.

O aparelho utilizado para medir a iluminação tem o sensor com o pico de sensibilidade no verde, e menor no vermelho e azul. Este fato é importante, pois o verde é a faixa do espectro mais refletida pelas folhas.

\subsubsection{Fitossociologia das fisionomias de cerrado}

Em parceria com MSc. Marco Antônio Batalha, foi realizado o levantamento de parâmetros fitossociológicos. Foram utilizados dados de área basal e altura obtidos nesse levantamento, com a finalidade de comparar o volume médio com o IVDN. A análise fitossociológica completa foi realizada por Batalha (1997).

Foram registrados dados sobre a estrutura vertical de 3 fisionomias de cerrado e 1 formação, que ocorrem na gleba Pé-de-Gigante: a floresta estacional semidecidual, o cerradão, o cerrado senso estrito e o campo cerrado. Para a floresta estacional semidecidual e cerradão foram amostrados: a-) componente arbóreo em parcelas de 10m x 25m (indivíduos com diâmetro do caule no nível do solo maior que $10 \mathrm{~cm}$ ), b-) componente arbustivo - arbóreo em parcelas de $4 \mathrm{~m}$ x 10m (indivíduos com diâmetro do caule no nível do solo maior que $1 \mathrm{~cm}$ e menor que $10 \mathrm{~cm}$ ), c-) componente herbáceo - arbustivo em parcelas de 1m por 2,5m (indivíduos com diâmetro do caule no nível do solo maior que $1 \mathrm{~cm}$, excluindo as plântulas). E no cerrado senso estrito e no campo cerrado foram amostrados: a-) componente arbustivo-arbóreo em parcelas de 4m x 10m (indivíduos com diâmetro do caule no nível do solo maior que $1 \mathrm{~cm})$, b-) componente herbáceo-arbustivo em parcelas de $1 \mathrm{~m}$ por $2,5 \mathrm{~m}$ (indivíduos com diâmetro do caule no nível do solo maior que $1 \mathrm{~cm}$, excluindo as plântulas). Foram registrados o perímetro do caule e a altura máxima dos indivíduos de cada parcela. 


\subsubsection{Posicionamentos com o GPS}

O GPS serviu no registro das coordenadas geográficas de locais de interesse na área de estudo. Em algumas situações, a cobertura vegetal dificultou a tomada destes dados. Nesse trabalho os registros foram realizados numa clareira ou sobre as árvores (acima do dossel). Em cada local, foram registrados dez posicionamentos, tomados de 10 em 10 segundos. Foram registrados pontos onde ocorrem as fisionomias para a posterior checagem das áreas de ocorrência. Foram registrados pontos para avaliação do erro de posicionamento do GPS em relação a carta topográfica utilizada como base geográfica. O sistema também foi utilizado para a navegação até áreas de ocorrência de fisionomias e checagem das mesmas.

\subsubsection{Registro da Cor do Solo superficial}

Nas diferentes fisionomias de cerrado foram amostrados solos superficiais para observação da cor. A seleção dos locais privilegiou áreas com formações campestres (campo limpo, campo cerrado e cerrado senso estrito). Nestes locais, a resposta espectral medida pelo satélite pode ter maior influência do substrato de fundo. Além disso, foram considerados os mapas pedológico e geológico para a seleção dos pontos de registro. Os pontos foram bem distribuídos sobre toda área de estudo; o solo fotografado e coletado com espátula (aproximadamente 300g). Em seguida, acondicionado em sacos plásticos até o laboratório, as amostras foram secas em estufa a 40 graus, registrando-se então a cor do solo seco e úmido, segundo a tabela de Munsell (Munsell Color, 1975).

\subsection{Estudo Piloto}

Para selecionar as fisionomias de cerrado existentes na área de estudo, fez-se um estudo prévio combinando imagens nas faixas espectrais do vermelho e 
infravermelho próximo, que gerou uma imagem índice de vegetação. Foi utilizado o índice de vegetação de diferença normalizada IVDN (Eq. 3.4.1.). O IVDN foi obtido a partir das informações espectrais contidas nas faixas TM-3 e TM-4 da imagem de 05 de julho de 95 .

$$
\mathrm{NDVI}=\frac{\left(\mathrm{ND} \text { infravermelho próximo }-\mathrm{ND}_{\text {vermelho }}\right)}{\left(\mathrm{ND}_{\text {infravermelho próximo }}+\mathrm{ND}_{\text {vermelho }}\right)}
$$

A imagem digital é uma matriz, tendo em cada cela um número digital (ND). No caso de uma imagem de satélite, este número é proporcional ao brilho dos materiais que compõem a superfície da Terra. A resolução radiométrica do sistema TM é de 8 bits $\left(2^{8}\right)$, ou seja, o sistema é capaz de distinguir 256 níveis de energia (ND de 0 a 255) que resulta da radiância dos alvos.

A imagem índice de vegetação, por sua vez, contém em cada cela não mais o ND e sim índices (ou índices de vegetação), que variam desde valores negativos até positivos, dependendo da densidade de vegetação por área que compõe a paisagem. Os solos nus terão os IVs negativos e as florestas densas os IVs positivos, por exemplo. Deste modo, este método quantitativo permite a classificação dos intervalos de IVs conforme as classes de interesse existentes no campo. Além disso, é possível calcular área e perímetro de cada classe.

Para se chegar às classes fisionômicas existentes na área de estudo, classificouse a imagem IV (valores variando de -0,1515152 a 0,6774194), inicialmente, em 14 classes, uma vez que o IDRISI dispõe de um padrão de cores (padronizado internacionalmente) bastante contrastante e de fácil visualização para até 16 classes.

Foi realizada uma viagem à campo com o objetivo de checar os resultados obtidos com a imagem índice de vegetação, classificada em 14 classes. Destas, apenas 9 classes ocorriam dentro da gleba Pé-de-Gigante. Então, foram escolhidos os pontos nucleares nas manchas de cada uma das classes, e as coordenadas destes pontos foram armazenadas na memória do GPS. A imagem final, com as classes e os pontos, foi impressa e levada à campo para auxiliar na navegação com o GPS (fig. 3.4.1). 


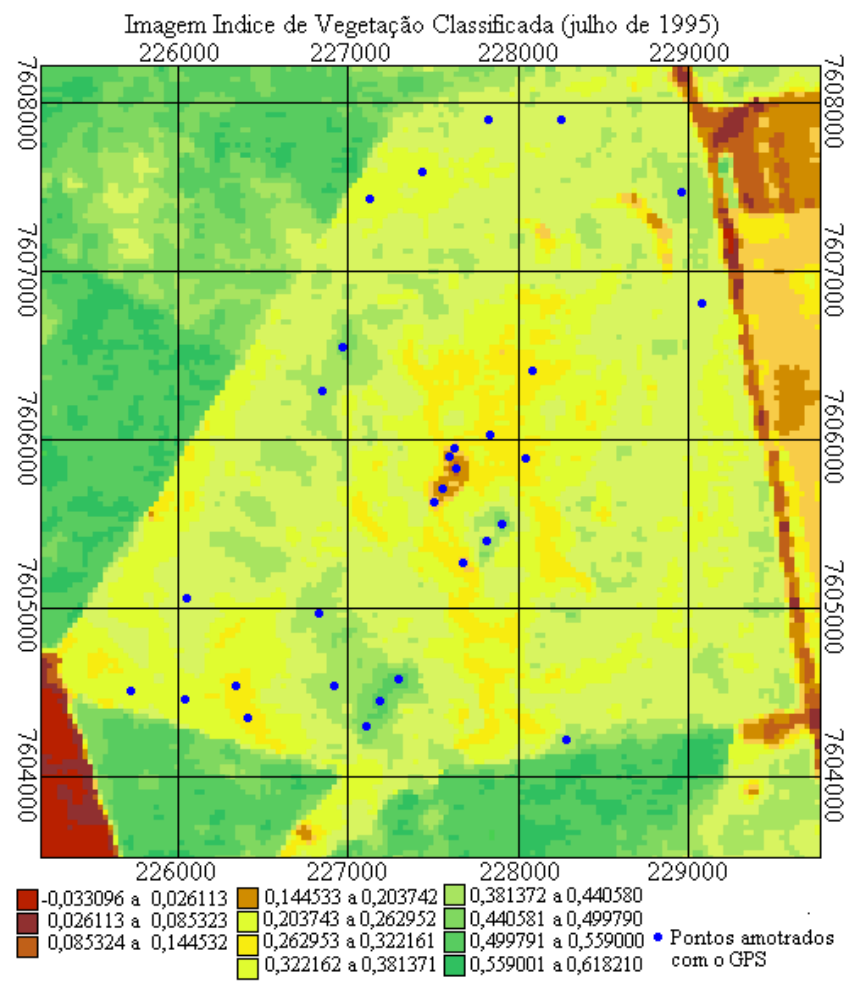

Figura 3.4.1 - Mapa utilizado em campo para a localização das manchas, com os intervalos de valores das 9 classes de índice de vegetação que ocorrem na gleba Pé-de-Gigante. Os pontos em azul correspondem a posição aproximada dos mesmos na imagem. Imagem índice de vegetação a partir das imagens de 05/07/95 (Bitencourt et alii, 1997).

Em campo, com o auxílio do GPS, no modo navegação, foram percorridos os pontos previstos, observadas as formas fisionômicas da vegetação, registrada uma descrição e um croqui de diagrama de perfil de cada uma das classes checadas (30 locais, nove croquis).

A imagem IVDN foi reclassificada, com algumas faixas de valores agrupadas em classes maiores. Este procedimento foi realizado com base nas informações obtidas na checagem das classes em campo, de modo que, cada mancha pudesse representar as fisionomias observadas em campo.

A tabela 3.4.1 apresenta as características das fitofisionomias observadas em campo. Esta descrição foi realizada a partir das observações de campo de características fisionômicas (fotografias, croquis, anotações), que, por sua facilidade, se prestam à discriminar estas fisionomias. Em conjunto, foram adicionadas informações da flora (Batalha, 1997), correspondentes às espécies mais abundantes de 
ocorrência exclusiva na fisionomia e que pudessem auxiliar a identificação das fisionomias em campo.

Tabela 3.4.1 - Fitofisionomias, classes IVDN e descrição baseada em observações de campo. Fonte: Bitencourt et alii (1997).

campo sujo - (IVDN $=0,0261$ a 0,2036$)$

Ocorre nas encostas mais íngremes. Há predomínio de gramíneas de, no máximo, 0,5m de altura, com algumas arvoretas ou arbustos esparsos e, em alguns locais, há grande concentração de pteridófitas. Em muitos locais o solo está totalmente exposto.

campo úmido - (IVDN $=0,0261$ a 0,2036$)$

Acompanha as áreas de drenagem, com espécies típicas de solo úmido ou periodicamente inundado. Predominam gramíneas e ciperáceas altas $(0,5$ a $1,0 \mathrm{~m}$ de altura), cujos ramos florais ultrapassam 2,0m de altura. Nesta fisionomia, surgem várias espécies invasoras, que se concentram em grandes manchas, como, por exemplo, Pteridium aquilinum (L.) Kuhn (Dennstaedtiaceae), Achyrocline satureoides (Lam.) DC. (Asteraceae), Andropogon bicornis L., Melinis minutiflora Beauv. (capim-gordura) e Panicum parvifolium Lam., Brachiaria sp Trin. (Poaceae), Imperata brasiliensis (sapé).

campo cerrado - (IVDN $=0,2037$ a 0,2629$)$

Há predomínio do estrato herbáceo-subarbustivo, ocorrendo arbustos de até $2 \mathrm{~m}$ de altura; árvores de 7-10m de altura ocorrem muito esparsamente. Nesta fisionomia é possível caminhar facilmente e visualizar grandes distâncias através da vegetação.

cerrado senso estrito - (IVDN $=0,2630$ a 0,3813$)$

$\mathrm{O}$ estrato predominante é formado por arbustos e arvoretas de até $5 \mathrm{~m}$ de altura, em grande adensamento, dificultando a locomoção e restringindo o campo de visão. Árvores emergentes, com 7 a $10 \mathrm{~m}$ de altura, surgem eventualmente. O estrato herbáceo-subarbustivo não é contínuo, mas recebe incidência direta de luz.

cerrado senso estrito tendendo a cerradão - (IVDN $=0,3814$ a 0,4405$)$

Há predomínio de árvores de até $10 \mathrm{~m}$ de altura, que não chegam a formar um dossel contínuo, mas provocam razoável sombreamento nos estratos mais baixos e, em conseqüência, um microclima mais ameno. O estrato herbáceo é ralo, com presença de muitas plântulas do componente dominante. Já se observa uma camada contínua de serapilheira.

cerradão - (IVDN $=0,4406$ a 0,5589$)$

Embora não atinja o máximo grau de desenvolvimento que poderia ser encontrado nesta fisionomia dentro do estado de São Paulo e não se forme um dossel contínuo, predominam árvores com cerca de $10 \mathrm{~m}$ de altura, que provocam razoável sombreamento e microclima mais ameno nos estratos inferiores. O componente herbáceo é pouco desenvolvido, com a presença de muitas plântulas do estrato dominante. Pode-se observar uma camada contínua de serapilheira.

floresta estacional semidecidual - $(\mathrm{IVDN}=0,4406$ a 0,5589$)$ 
Nesta formação, o estrato arbóreo superior a 10m, formando um dossel contínuo. Algumas árvores emergentes, principalmente Anadenanthera macrocarpa (Benth.) Brenam (Mimosaceae), atingem cerca de $20 \mathrm{~m}$ de altura. O subosque é dominado por Actinostemon communis M. Arg. (Euphorbiaceae). O componente herbáceo é pouco desenvolvido, formado por espécies tipicamente umbrófilas, como, por exemplo, rubiáceas e marantáceas. Lianas são freqüentes e há um aumento na quantidade de epífitas em relação às fisionomias de cerrado. A camada de serapilheira é contínua ao longo de toda esta fisionomia.

A figura 3.4.2. ilustra o mapa preliminar das fitofisionomias observadas em campo, foi produzido a partir da imagem de julho de 1995. Este mapa representa a distribuição espacial das principais fitofisionomias observadas na área de estudo. Podemos observar que as formas campestres estão localizadas na parte mais central da gleba (nas proximidades da rede de drenagem) e as formas florestais nas partes mais externas.

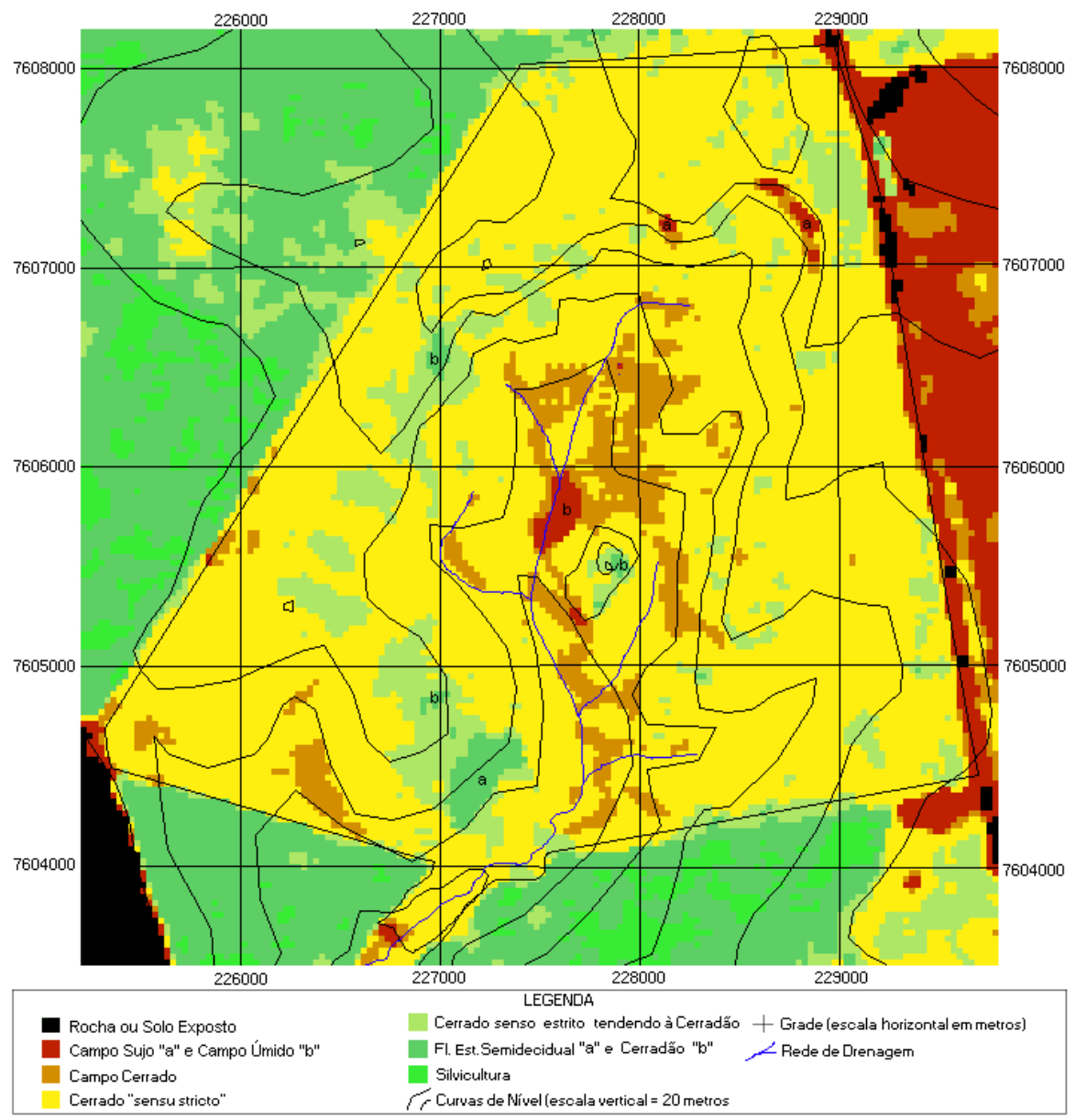

Figura 3.4.2 - Mapa preliminar das fitofisionomias observadas em campo, o mapa foi produzido a partir de imagem IVDN de julho de 1995 (Bitencourt et alii, 1997). 
Estes resultados preliminares (descrição e mapa preliminar das fitofisionomias) serviram como subsídios para as atividades seguintes. Na ocasião da elaboração deste mapa, suspeitava-se que a delimitação das áreas de cada tipo de fisionomia poderia estar superestimada ou subestimada. Depois de mais algum tempo de utilização do mapa, foram constatadas fitofisionomias que ocorriam em áreas restritas e pequenas, mas que estavam sendo classificadas como fisionomia de cerrado. As fisionomias de cerradão e floresta estacional semidecidual estavam com valores de IVDN semelhantes. Suspeitava-se que imagens em outras datas também poderiam diminuir o grau de confusão destas fisionomias, em decorrência das modificações de cada tipo fisionômico ao longo do ano.

\subsection{Métodos}

Inicialmente, as imagens de cinco datas foram registradas, de modo a ficarem idênticas geograficamente, ou seja, com o mesmo tamanho e resolução. As imagens, com a área de estudo selecionada, ficaram armazenadas em forma de número digital com 182 colunas por 182 linhas. O sistema de referência geográfica adotado foi o Universal Transverse Mercartor (UTM) ou Coordenadas Planas com datum Córrego Alegre-MG, medida em metros, de oeste para leste, iniciando em $224.730 \mathrm{~m}$ e terminando em $230.190 \mathrm{~m}$ e de Sul para Norte iniciando em $7.603 .200 \mathrm{~m}$ e terminando em $7.608 .660 \mathrm{~m}$, e com resolução de $30 \mathrm{~m}$ por $30 \mathrm{~m}$ para cada cela (isto é, cada cela da imagem representa uma área quadrada no terreno de 0,09 ha).

Todas as imagens tiveram seus valores de ND convertidos para uma grandeza física (Robinove, 1982, Markham \& Barker, 1986). Inicialmente foram convertidos para radiância espectral medida no satélite e desta convertida para reflectância espectral no nível do satélite (ou reflectância exoatmosférica).

A primeira etapa no processo de conversão foi a transformação dos números digitais em valores de radiância espectral $\left(L_{\lambda}\right)$, na faixa do comprimento de onda $\lambda$ 
(Eq. 3.5.1.). Esta conversão é linear e está relacionada com as características do sensor na faixa espectral específica. Para a conversão é utilizada uma função linear.

$\mathrm{L}_{\lambda}=$ Constante $\lambda+$ Coeficiente $\lambda \mathrm{X} \frac{\text { Número Digital }}{\text { Número Digital Máximo }}$

Equação 3.5.1.

As constantes e os coeficientes são específicos para cada faixa espectral e podem variar na ocasião da coleta de dados. No caso do satélite Landsat 5 as lâmpadas internas utilizadas na calibração do sensor estão deterioradas. Considerando estas condições, os valores da constante e do coeficiente utilizados neste trabalho são aqueles utilizados no instante da calibração dos sensores antes do lançamento do satélite. A tabela 3.5.1 mostra os valores de radiância máxima e mínima para os dados processados nos EUA (os valores são iguais aos das imagens calibradas e fornecidas pelo INPE).

Tabela 3.5.1 - Variações dinâmicas de dados pós-calibrados do TM para dados processados nos EUA (para imagens processadas após 15 de Janeiro de 1984).

\begin{tabular}{|c|c|c|c|}
\hline \multicolumn{2}{|c|}{$\begin{array}{l}\text { Faixa Espectral } \\
\text { (em mm) }\end{array}$} & \multirow{2}{*}{$\begin{array}{c}\begin{array}{c}\text { Radiância Mínima } \\
\left(\mathrm{mW} \cdot \mathrm{cm}^{-2} \cdot \mathrm{SR}^{-1} \cdot \mathrm{mm}^{-1}\right.\end{array} \\
-0,1500\end{array}$} & \multirow{2}{*}{$\begin{array}{c}\begin{array}{c}\text { Radiância Máxima } \\
\left.\mathrm{mW} \cdot \mathrm{cm}^{-2} \cdot \mathrm{SR}^{-1} \cdot \mathrm{mm}^{-1}\right)\end{array} \\
15,2100\end{array}$} \\
\hline 0,45 & - $\quad 0,52$ & & \\
\hline 0,52 & $-\quad 0,60$ & $-0,2800$ & 29,6800 \\
\hline 0,63 & $-\quad 0,69$ & $-0,1200$ & 20,4300 \\
\hline 0,76 & - $\quad 0,90$ & $-0,1500$ & 20,6200 \\
\hline 1,55 & - $\quad 1,75$ & $-0,0370$ & 2,7190 \\
\hline 10,40 & $-12,50$ & 0,1238 & 1,5600 \\
\hline 2,08 & $-\quad 2,35$ & $-0,0150$ & 1,4380 \\
\hline
\end{tabular}

Fonte: Modificado a partir de Markham \& Barker, 1986.

A segunda etapa foi a conversão (Eq. 3.5.2.) dos valores de radiância espectral em reflectância no nível da satélite ou exoatmosférica $(\rho)$. Esta conversão é importante, pois os valores de irradiância do sol são diferentes (Robinove, 1982, Hill, 1991) nas cinco datas, em decorrência das variações no ângulo de elevação solar durante o ano. 


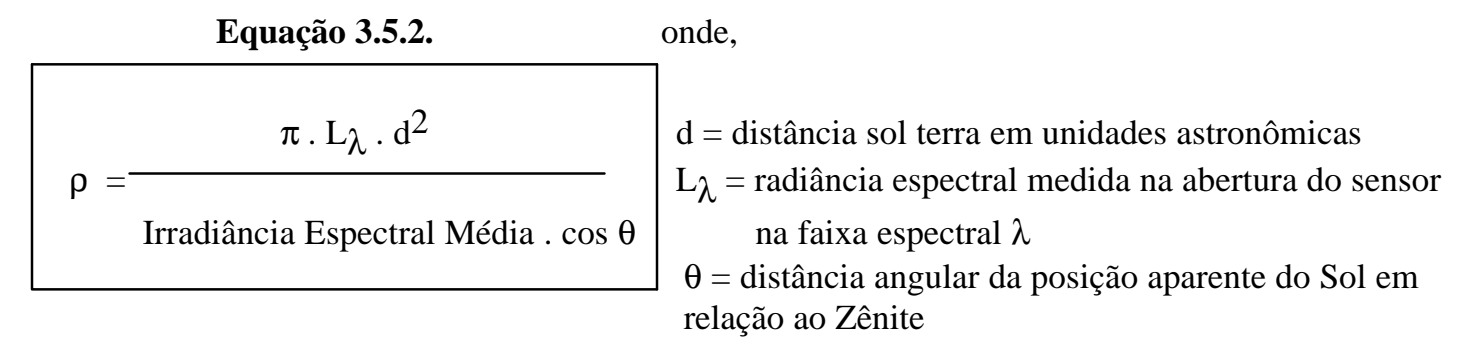

Na data de janeiro de 1996, a distância Sol/Terra em unidades astronômicas foi obtida no anuário astronômico do IAG (Boczko, 1995). Para as datas dos anos de 1995 e 1997, as distâncias foram obtidas através do fator de correção da excentricidade da órbita da terra, que permite conhecer o valor aproximado da distância Sol/Terra para todos os dias da semana (Iqbal, 1983).

A distância angular da posição aparente do Sol em relação ao Zênite (z) foi obtida pela fórmula (Eq. 3.5.3.) apresentada no trabalho de Colwell (1983).

$\mathrm{Z}=\operatorname{arco} \operatorname{coseno}($ seno $\phi$. seno $\Delta+\operatorname{coseno} \phi . \operatorname{coseno} \Delta . \operatorname{coseno} \mathrm{H})$

Equação 3.5.3.

onde:

$\phi=$ Latitude do observador, $\Delta=$ Declinação do Sol no instante e H = Ângulo horário do Sol

O ângulo horário do Sol no instante é obtido, segundo Boczko (1995), subtraíndo-se do tempo sideral local (TSL) a ascensão reta do Sol (Eq. 3.5.4.). A ascensão reta do Sol para os três instantes desejados foi obtida nos respectivos anuários astronômicos (Stavinschi et alii, 1994 e Observatório Nacional, 1996).

Equação: 3.5.4 onde: TU = Tempo Universal (HFL-F)

TSL = TU.1,0027379+TSG-1 F = Fuso Horário (para toda a costa atlântica do Brasil o valor é $-3 \mathrm{~h}$ ) TSG $=$ Tempo Verdadeiro em Grenwich à 0 horas UT .

O valor da distância Zenital é o ângulo complementar do Ângulo de Elevação Solar (a), equação 3.5.5.

$a=90^{\circ}-z$

sendo, a e z em graus.

Equanção 3.5.5 
O ângulo azimutal para o instante desejado foi obtido, simplesmente, convertendo o valor do instante do registro das imagens em horas para graus, e somando a este 180 graus (ou 12 horas) para obter a distância em relação ao norte geográfico.

Com o ângulo de elevação solar e o ângulo azimutal para os instantes das três datas foi possível obter a imagem de sombreamento do relevo. Estas imagens serviram para a identificação das áreas que sofreram sombreamento no momento do imageamento.

As imagens não foram corrigidas quanto aos possíveis efeitos de espalhamento e atenuação atmosférica.

As imagens para cada data foram transformadas em imagens IVDN (Eq. 3.5.6.), e foi selecionada apenas a área dentro da gleba Pé-de-Gigante. Foi excluída uma faixa de cem metros a partir dos limites da reserva, para finalidade de amostragem de áreas representativas de cada fisionomia na imagem. As áreas muito próximas da borda estão sujeitas a interferência da parte externa.

$$
\text { NDVI }=\frac{(\rho \text { infravermelho próximo }-\rho \text { vermelho })}{(\rho \text { infravermelho próximo }+\rho \text { vermelho })} \quad \rho=\begin{gathered}
\text { reflectância } \\
\text { exoatmosférica }
\end{gathered} \quad \text { Equação 3.5.6. }
$$

Foram coletados dados de campo nos períodos de chuva e de estiagem. Foram realizadas transeções com a descrição dos tipos fisionômicos que ocorriam no percurso. Foram obtidos, para cada fisionomia: dados de iluminação relativa e percentual de abertura do dossel. Estes dados serviram para estimar de forma qualitativa as variações da cobertura vegetal das fisionomias de cerrado senso lato no período úmido e seco.

Com as imagens IVDN nas cinco datas, mais os dados obtidos em campo e os dados cartográficos, foram delimitadas as áreas de ocorrência das fisionomias. Foram extraídos os IVDNs médios das áreas correspondentes às fisionomias identificadas preliminarmente em campo. Estes valores foram, então, comparados com o clima regional. Os valores médios de IVDN para cada fisionomia foram também 
comparados com dados de três trabalhos realizados na área nuclear do cerrado; no planalto central do Brasil, descritos a seguir.

Bitencourt-Pereira (1986) realizou o trabalho de correlação da biomassa aérea de campo cerrado. Foram obtidos valores de IVDN na faixa do MSS 6 e MSS 7. As imagens foram corrigidas quanto ao ângulo da elevação solar, multiplicando os valores de radiância por seno do ângulo de elevação normalizado, por um valor eleito (tab. 10.1). As amostras do mesmo local foram resumidas às médias para simplificar a representação gráfica.

Santos (1988) realizou um trabalho, também no planalto central, utilizando como objeto de estudo o cerrado senso estrito, e obteve os valores de IVDN com as faixas espectrais do Landsat TM 4 e 3. Neste trabalho fez correlação e estimativa de biomassa com dados do satélite Landsat Thematic Mapper utilizando valores de reflectância exoatmosférica (tab. 10.2).

França (1994) realizou um trabalho no Parque Nacional de Emas, utilizando imagens do sensor AVHRR do Satélite NOAA. Os valores de radiância foram normalizados da mesma forma descrita no trabalho de Bitecourt-Pereira (1986). Neste caso a resolução espacial ${ }^{9}$ no terreno para esta imagens é muito diferente $(1 \mathrm{~km} \mathrm{x}$ $1 \mathrm{~km}$ ). O objeto de estudo foi o campo limpo e o campo sujo de cerrado, onde ocorre predomínio de capim-flexa (tab. 10.3).

As áreas delimitadas como de ocorrência das fitofisionomias foram avaliadas, quanto à posição, por meio de posicionamentos do GPS, realizados em locais espalhados por toda área de estudo, nas diferentes fisionomias. Sobrepondo-se o posicionamento do GPS nas áreas de ocorrência obteve-se o percentual de coincidência e confusão. Como os pontos estão sujeitos a um erro de posicionamento de $100 \mathrm{~m}$, foi considerada uma área aproximadamente circular com 100m de raio para cada posicionamento. Assim, cada ponto registrado com o GPS para uma determinada fitofisionomia foi associado a 36 pontos (de $30 \mathrm{~m}$ por $30 \mathrm{~m}$ ) na imagem. Estas informações foram sobrepostas na imagem classificada com as áreas de maior probabilidade de ocorrência, e assim analisado o percentual de acerto e de confusão de algumas classes. 
O IVDN foi avaliado quanto ao possível efeito da topografia. Foram comparados os valores de IVDN de uma mesma fisionomia obtidos em vertentes com diferentes orientações em relação ao Sol e também o IVDN na superfície plana.

Para analisar a possível interferência da cor do solo (de fundo) no IVDN obtido para as diferentes fisionomias, foi registrada em campo a cor do solo superficial em 21 posições da área de estudo. A seleção da posição dos locais de registro foi feita com auxilio dos mapas de topografia, pedologia e geologia da gleba.

Para cada área de ocorrência das fitofisionomias foram extraídos também os valores médios de altitude e de declividade e a área em hectares (projeção da área superficial).

\section{Resultados Primários}

Neste item serão apresentados os resultados iniciais, que serviram como base para a obtenção dos dados posteriores. Estes resultados estão apresentados à parte, pois não participam do objetivo final da pesquisa, porém foram importantes para a validação de todos os resultados obtidos.

A primeira etapa do trabalho consistiu na obtenção de uma base geográfica para a sobreposição das imagens de satélite e dos dados obtidos em campo. Para produzir um mapa com as informações geográficas do terreno foram precisos dois mapas topográficos na escala 1:10.000 do IGC, que cobriram a maior parte da área de estudo (IGC, 1990a e 1990b), o restante foi produzido com a carta 1:50.000 do IBGE (1971). Neste pedaço do mapa foram interpoladas as curvas de nível de 5 em 5 metros, no mapa estavam apenas as cotas de 20 em 20 metros. Então, foram digitalizadas as seguintes informações dos 3 mapas: as cotas altimétricas da área de estudo, as rodovias que delimitam a área de estudo e a rede de drenagem. As informações digitalizadas (transformação de formas geométricas para o formato digital) serviram como referência para relacionar as demais informações reunidas a seguir no sistema de informações geográficas (fig. 4.1.a). 
(a)

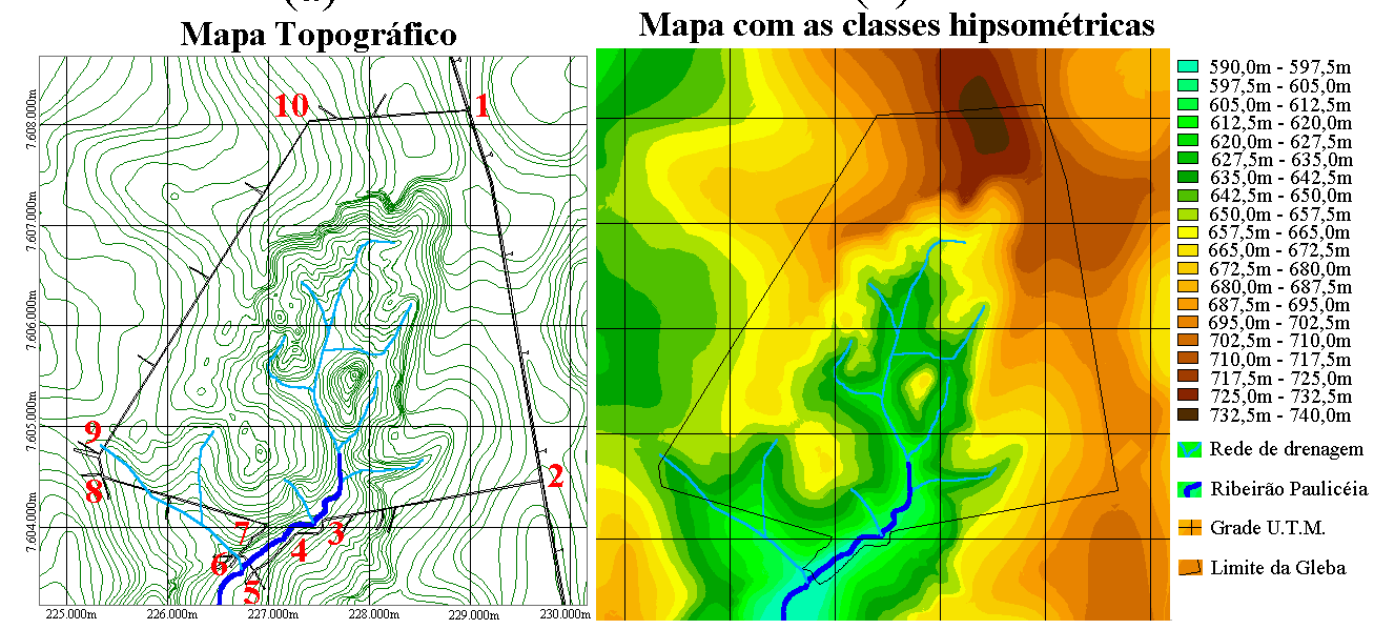

Figura 4.1 - a.) Mapa topográfico da gleba Pé-de-Gigante com a as cotas altimétricas, as rodovias que delimitam a área e a rede de drenagem. Os números em vermelho indicam os pontos de referência geográfica. b.) Mapa hipsométrico da área de estudo, as cores representam as classes de elevação do terreno.

Além de possibilitar o refinamento de processos de geo-referenciamento, as curvas de nível digitalizadas foram também utilizadas para gerar uma superfície ou modelo digital de elevação do terreno ${ }^{5}$ - MDT (fig. 4.2.a.), a partir do qual se obtém mapas: hipsométricos (4.1.b.), de declividade ${ }^{7}$ (4.2.b.) e de orientação de vertentes (4.2.c.).

A partir do mapa de orientações de vertentes e do mapa de declividades foram selecionadas áreas com declividade superior a 7 graus separadas em quatro classes, de acordo com a orientação das vertentes: de $315^{\circ}$ a $360^{\circ}$ e de $0^{\circ}$ a $45^{\circ}$ vertente Norte, de $45^{\circ}$ a $135^{\circ}$ vertente Leste, de $135^{\circ}$ a $225^{\circ}$ vertente Sul e de $225^{\circ}$ a $315^{\circ}$ vertente Oeste (fig. 4.2.d.). Então estas áreas foram utilizadas para a análise do efeito da topografia sobre o IVDN. 
(a)

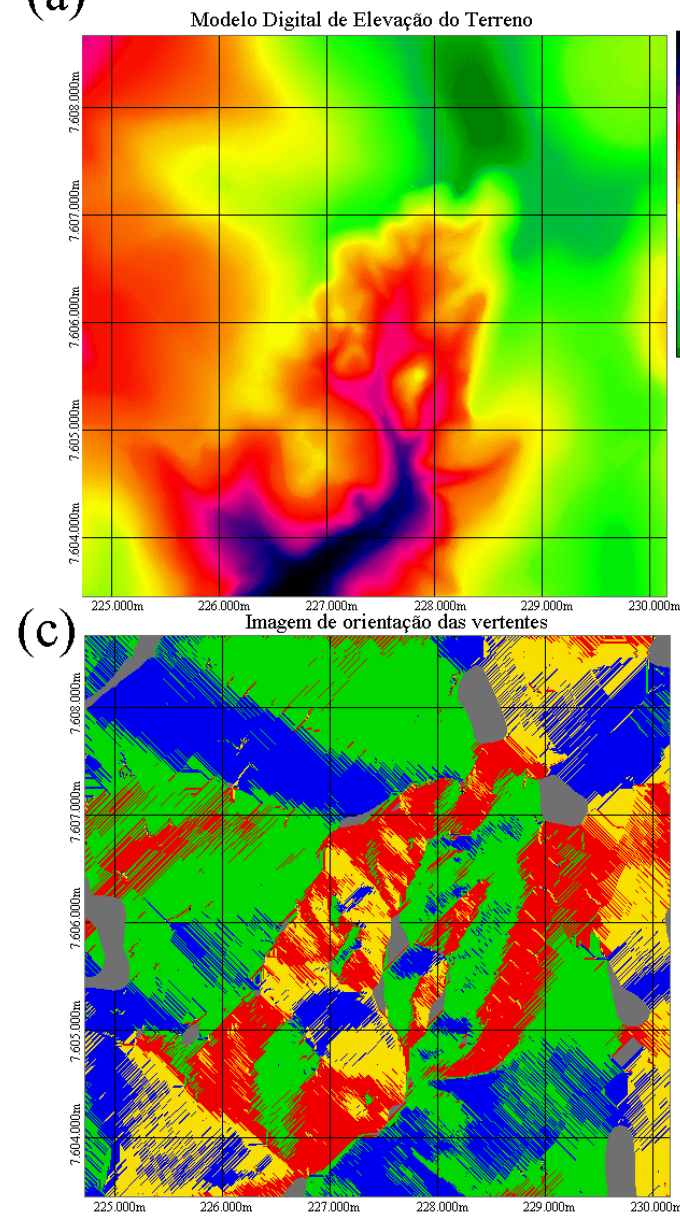

(b)
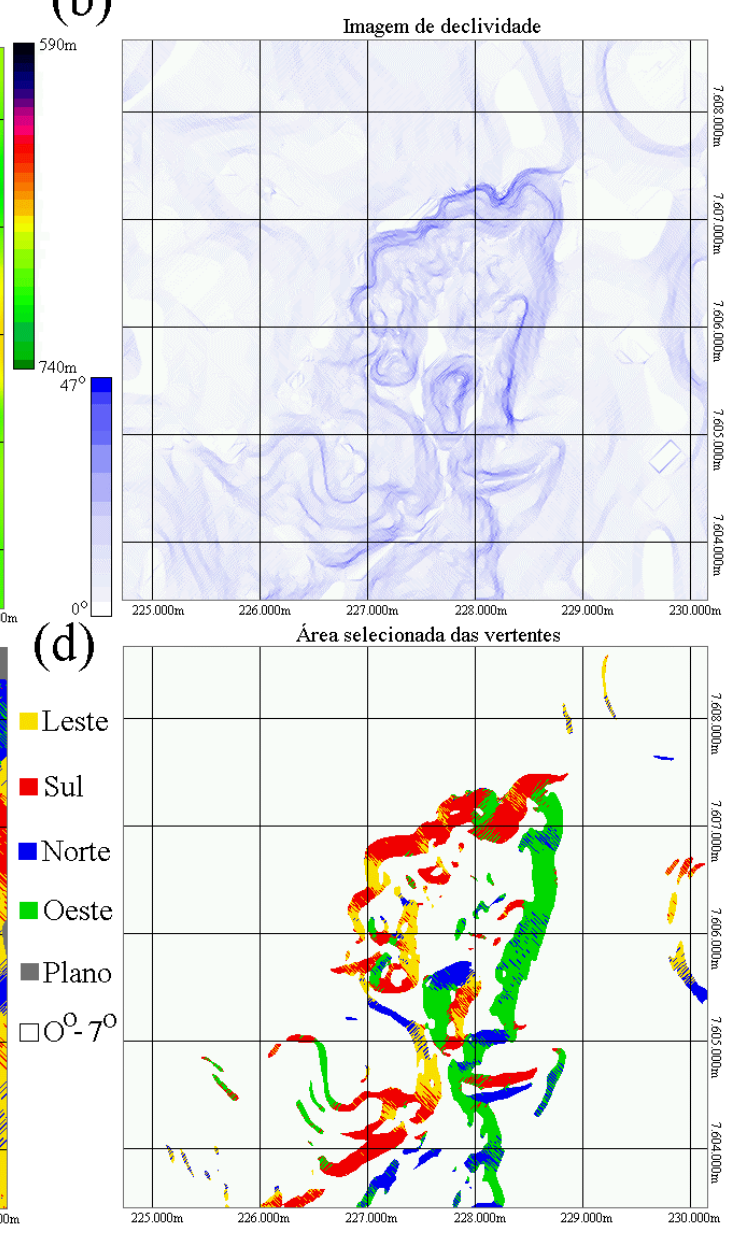

Figura 4.2. - a.) Imagem MDT; b.) Imagen de declividade ${ }^{7}$; c.) Imagem de orientação das vertentes ${ }^{8}$; d.) Imagem com a área selecionada com a orientação das vertentes Norte, Sul, Leste e Oeste, com declividade superior a 7 graus.

Para navegar sobre as imagens oriundas de satélites é preciso antes georeferenciá-las. Assim, foram selecionados 10 pontos de referência no mapa topográfico, nos limite da reserva, nas curvas e cruzamentos de vias (fig. 4.1.), de tal modo que pudessem ser encontrados com facilidade em campo. Com o GPS foram tomados posicionamentos, e estes foram comparados com os valores das coordenadas geográficas em UTM, obtidos no MDT. Para cada ponto, foi calculada a distância euclidiana (Eq. 4.1.) até as coordenadas obtidas pela média dos posicionamentos feitos com o GPS em campo (fig. 4.3.) e em relação aos pontos da imagens (tab. 4.1.). No caso das imagens, os pontos foram facilmente localizados por se encontrarem nas curvas ou cruzamentos de rodovias. As imagens brutas não possuíam um sistema de coordenadas geográficas; então um ponto (escolhido arbitrariamente o 
ponto 9) serviu de referência para os demais, para o cálculo da diferença de distância antes da correção geográfica das imagens. Após a correção, os pontos ficaram com a mesma posição geográfica da base cartográfica.

$$
\text { Distância Euclidiana }=\sqrt{\left(\mathrm{X}_{1}-\mathrm{X}_{2}\right)^{2}+\left(\mathrm{Y}_{1}-\mathrm{Y}_{2}\right)^{2}}
$$

Equação 4.1.

Tabela 4.1. - Coordenadas dos pontos de referência obtidas na base cartográfica e distância Euclidiana em relação aos pontos de referência obtidos por GPS e nas 5 imagens em diferentes datas.

\begin{tabular}{lllllllll}
\hline \multicolumn{1}{c}{ Ponto Ref. X Ref. Y } & GPS & agosto-95 & julho-95 & janeiro-96 & julho-96 junho-97 \\
\hline 1 & 228973 & 7608123 & 25 & 893 & 700 & 874 & 879 & 721 \\
2 & 229697 & 7604456 & 21 & 454 & 124 & 113 & 114 & 124 \\
3 & 227533 & 7604055 & 19 & 369 & 306 & 317 & 324 & 319 \\
4 & 227264 & 7603917 & 18 & 378 & 323 & 327 & 351 & 354 \\
5 & 226860 & 7603563 & 16 & 348 & 288 & 426 & 371 & 290 \\
6 & 226692 & 7603712 & 12 & 350 & 267 & 331 & 341 & 287 \\
7 & 226971 & 7604017 & 39 & 296 & 253 & 273 & 285 & 248 \\
8 & 225357 & 7604492 & 10 & 34 & 45 & 40 & 37 & 55 \\
9 & 225321 & 7604694 & 41 & 0 & 0 & 0 & 0 & 0 \\
10 & 227409 & 7608024 & 10 & 627 & 501 & 734 & 709 & 524 \\
\hline \multicolumn{1}{c}{ Média } & 21 & 375 & 281 & 343 & 341 & 292 \\
\hline
\end{tabular}




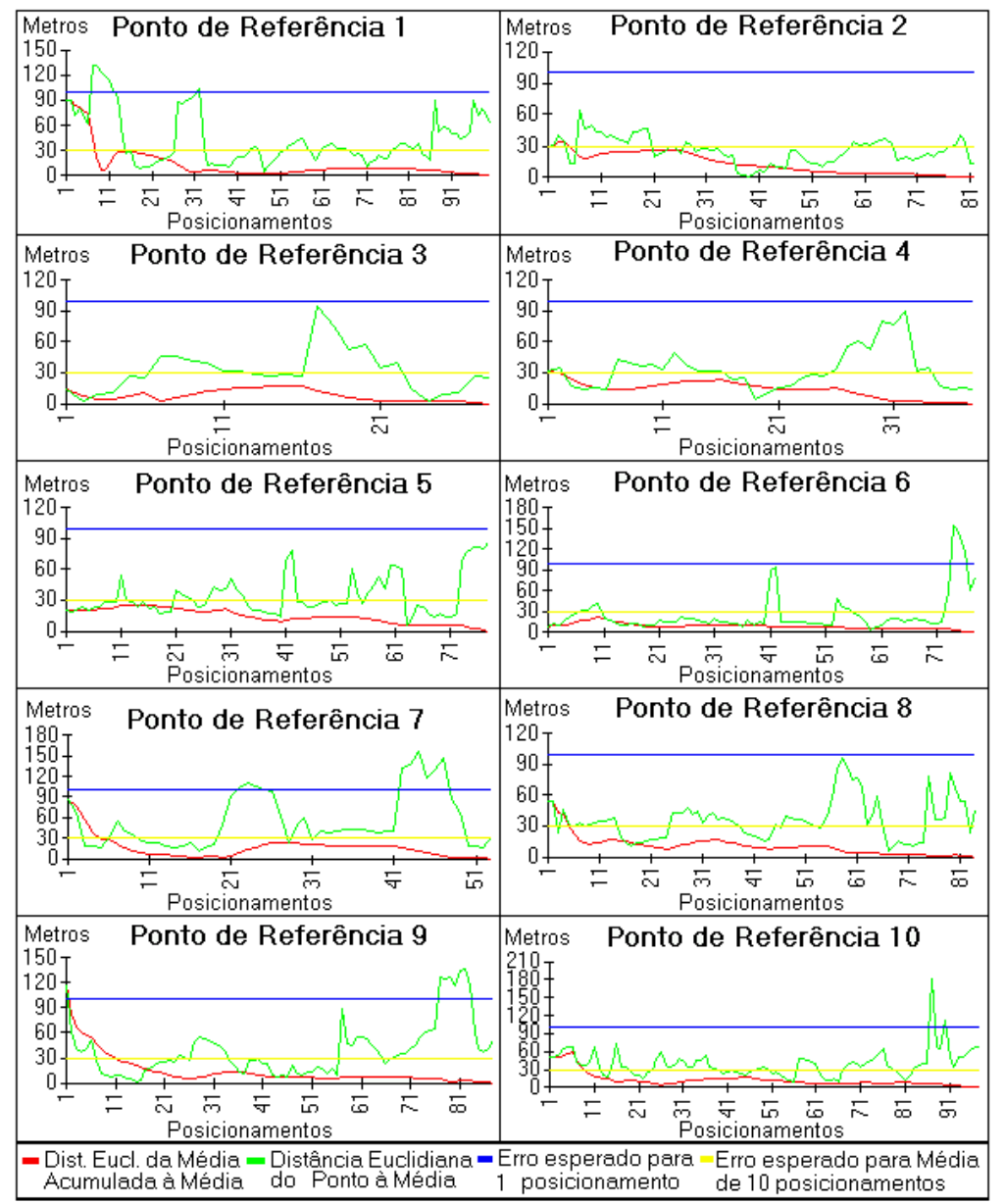

Figura 4.3. - Representação dos desvios , baseada na distância euclidiana, de cada ponto registrado com o GPS nos 10 locais de referência geográfica em relação a média (azul), e a representação dos desvio da média acumulada em relação a média obtida para todos os pontos amostrados (vermelho). As retas em verde escuro representam os desvios esperados para um único posicionamento $(100 \mathrm{~m})$ e a reta em verde claro os desvios esperados para a média de 10 posicionamentos $(30 \mathrm{~m})$.

Foram obtidos dados meteorológicos da área de estudo sob duas formas: dados mensais para análise de longo período e dados diários (quatro horários) para o período estudado. Os dados de longo período correspondem ao intervalo de 1985 até o primeiro semestre de 1997, e serviram para a construção do climadiagrama (fig. 3.1.2.). Ainda com os registros de longo período foram produzidos gráficos da variação da média mensal da umidade relativa, da insolação direta e da amplitude térmica, para o mesmo intervalo de anos (fig. 4.4.a). Foi produzido um gráfico (fig. 4.4.b) da variação diária do fotoperíodo ao longo de um ano. Neste caso foram utilizados os dados do Observatório Nacional - Ministério da Ciência e Tecnologia (Observatório Nacional, 1996) do ano de 1996. O fotoperíodo nesta região 
geográfica apresenta, ao longo do ano, variação no número de horas. Este fato é particularmente importante, pois esta luz é utilizada pelos vegetais para a fotossíntese, representando mais um fator da sazonalidade nesta área do estudo.

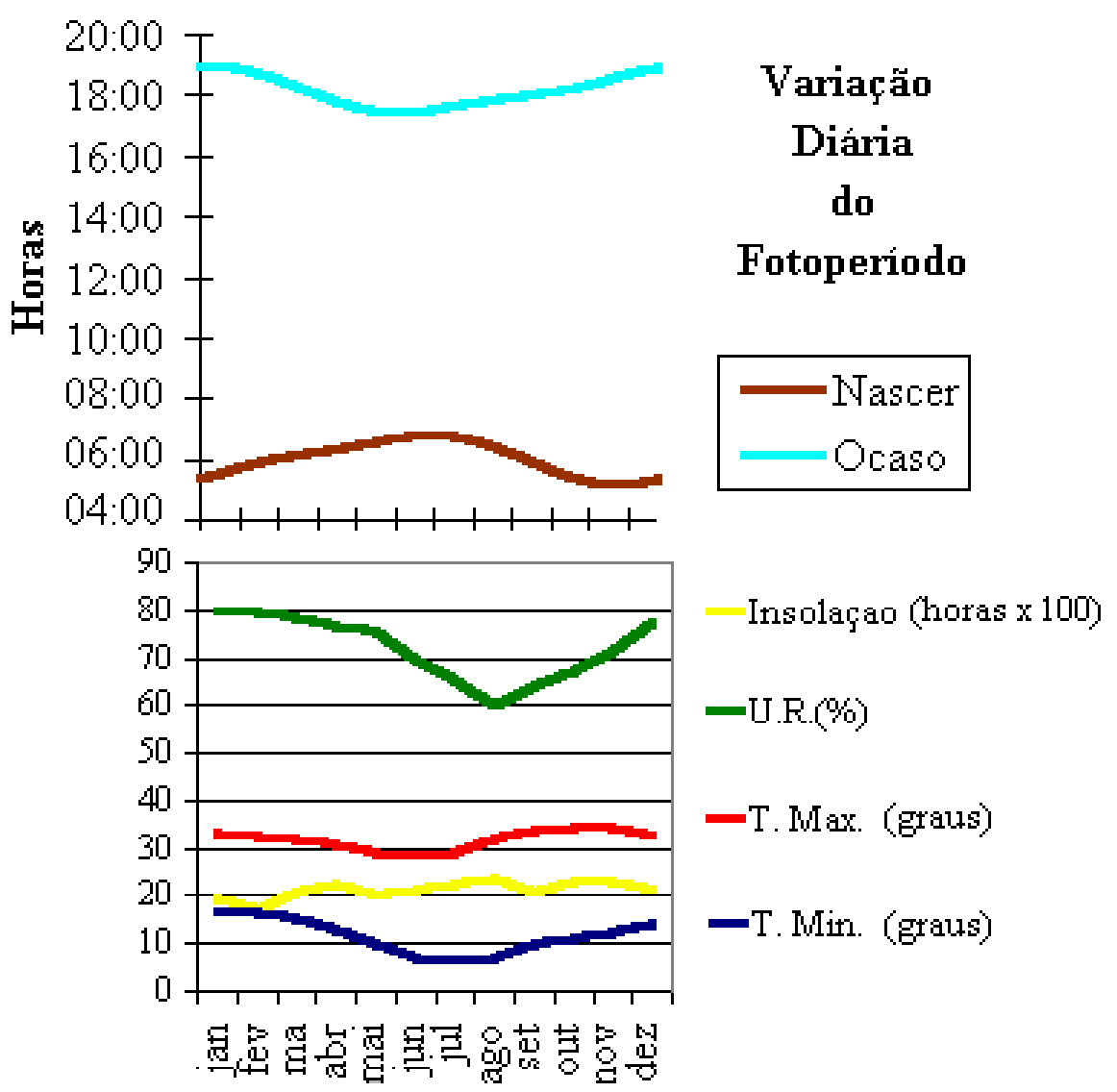

Fig. 4.4. - a.) Variação anual média da umidade relativa, insolação direta e da amplitude térmica. b.) Variação diária do fotoperíodo ao longo de um ano, os dados referem-se ao ano de 1996 (Observatório Nacional, 1996).

Os dados diários correspondem ao período de janeiro de 1994 até julho de 1997 e serviram para analisar as condições de tempo durante o período de estudo. A temperatura máxima é alta na maior parte do ano, porém no inverno, com ausência de formação de nuvens (zonas de alta pressão) à noite, a temperatura mínima pode atingir valores baixos. Isto ocasiona grande amplitude térmica nesta época do ano (fig. 4.5.a). A precipitação diária acumulada (fig. 4.5.b) indica os meses de maior pluviosidade no período de estudo, bem como a ausência de chuvas, registrada no mês de agosto de 1995 (estiagem muito forte). As imagens foram registradas em dias cujos antecedentes não apresentaram chuvas. 


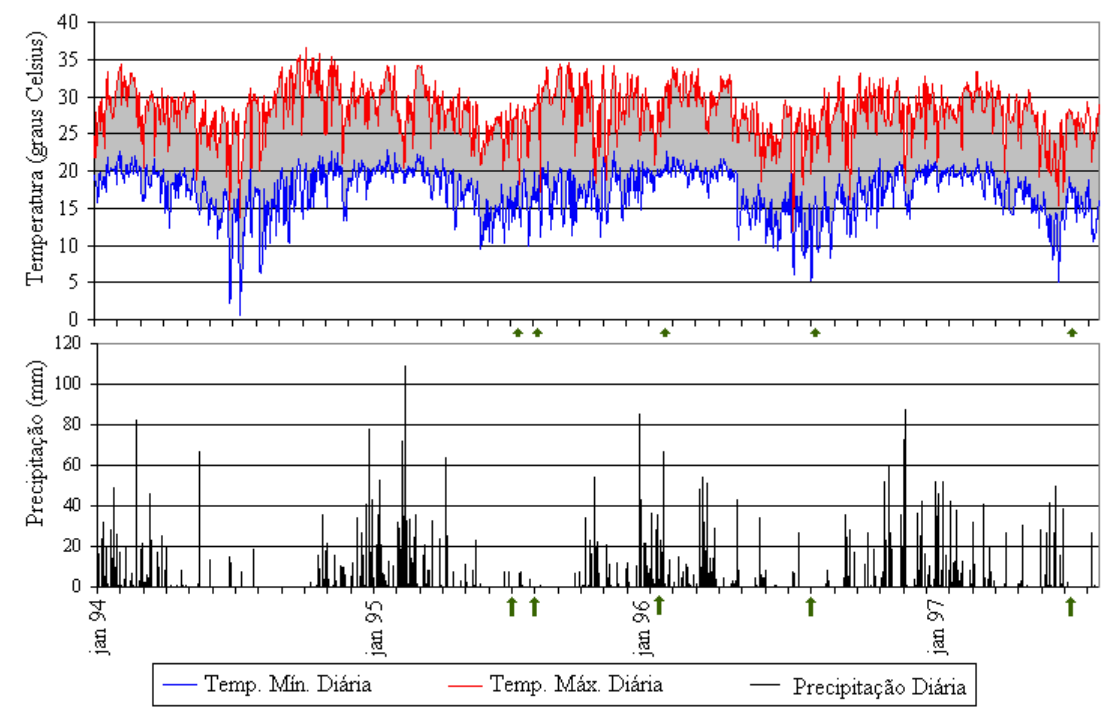

Fig. 4.5. - a.) Variação diária das temperaturas máxima e mínima absolutas e amplitude térmica, estação meteorológica de Santa Rita do Passa Quatro (C4-107, DAEE). b.) Precipitação diária acumulada ao longo do período de estudo, estação meteorológica de Santa Rita do Passa Quatro (C4-107, DAEE). As setas indicam a data de aquisição das imagens de satélite.

\section{Resultados e Discussão}

A vegetação estudada foi descrita do ponto de vista fisionômico por meio de perfils diagrama. De forma complementar, foram amostradas as fitofisionomias de cerrado, para medida de área basal, altura e densidade de indivíduos.

$\mathrm{Na}$ área de estudo ocorre um gradiente de fisionomias de cerrado e formações associadas. As fisionomias de cerrado encontradas na reserva são o campo cerrado, o cerrado senso estrito, o cerrado com herbáceo ralo, e o cerradão, as demais são fitofisionomias associadas representadas pelo campo úmido e campos com predomínio de Melinis minutiflora Beauv. (capim-gordura) e campo com predomínio de Pteridófitas. As fitofisionomias associadas aos morfotipos de cerrado que ocorrem na reserva, têm pouca importância florística e ocupam pequenas áreas. Estas áreas foram analisadas para evitar que fossem consideradas como áreas de cerrado. Batalha (1997) estudou a florística na reserva e encontrou $44 \%$ de espécies ruderais no total amostrado no campo úmido. A floresta ciliar apresentou baixa riqueza florística; e as 
fisionomias de campo cerrado, cerrado senso estrito, cerradão possuem espécies comuns a outras áreas de cerrado.

Os perfis diagrama foram produzidos nos principais tipos fisionômicos representativos do gradiente de aumento do componente arbóreo na área de estudo: o campo (campestre), campo cerrado, cerrado senso estrito, cerrado com herbáceo ralo, o cerradão e a floresta estacional semidecidual (florestal). Foram observadas fitofisionomias que apresentaram características particulares e receberam então denominações específicas.

As fisionomias campestres estão representadas pelo campo úmido, pelo campo limpo e campo de pteridófitas. Todas estas fisionomias foram observadas na parte mais central da área de estudo, e têm altura média em torno de $1 \mathrm{~m}$, os indivíduos são predominantemente herbáceos, e gramíneas, ciperáceas e pteridófitas. O solo nesta região é composto de areia quartzosa, com granulação de média a grossa, e nas partes que sofrem alagamento periódico existe um acúmulo de matéria orgânica o solo preto.

O campo úmido (fig. 5.1) ocorre dentro da rede de drenagem, e durante o período de maior pluviosidade ocorre alagamento da área, permanecendo assim por aproximadamente um mês. Neste local ocorrem, na maior parte, indivíduos de Andropogon bicornis L., que possuem de 1 a 1,5m de altura, mas os ramos florais podem atingir até $2 \mathrm{~m}$ de altura.

Nas proximidades do campo úmido encontra-se uma paisagem diferenciada, em decorrência da vegetação ser predominantemente composta de pteridófitas da espécie Pteridium aquilinum (L.) Kuhn (Dennstaedtiaceae). Os indivíduos têm de $1 \mathrm{~m}$ a 1,5m de altura e distribuem-se em mancha única e contínua. Embora situada na rede de drenagem, está posicionada na área pouco mais elevada em relação ao campo úmido e não foi observada a lâmina d' água durante o período de maior precipitação, porém permaneceu úmido.

Nas partes um pouco mais elevadas, áreas que não estão sujeitas ao alagamento, contudo próximas a rede de drenagem, ocorre campo limpo denominado, aqui, de campo limpo de Melinis. Estes campos são compostos, predominantemente, por Melinis minutiflora Beauv. (capim-gordura), porém em algumas áreas ocorrem 
manchas menores e continuas Imperata brasiliensis Trin. (sapé). Os indivíduos geralmente não ultrapassam 1 metro de altura.

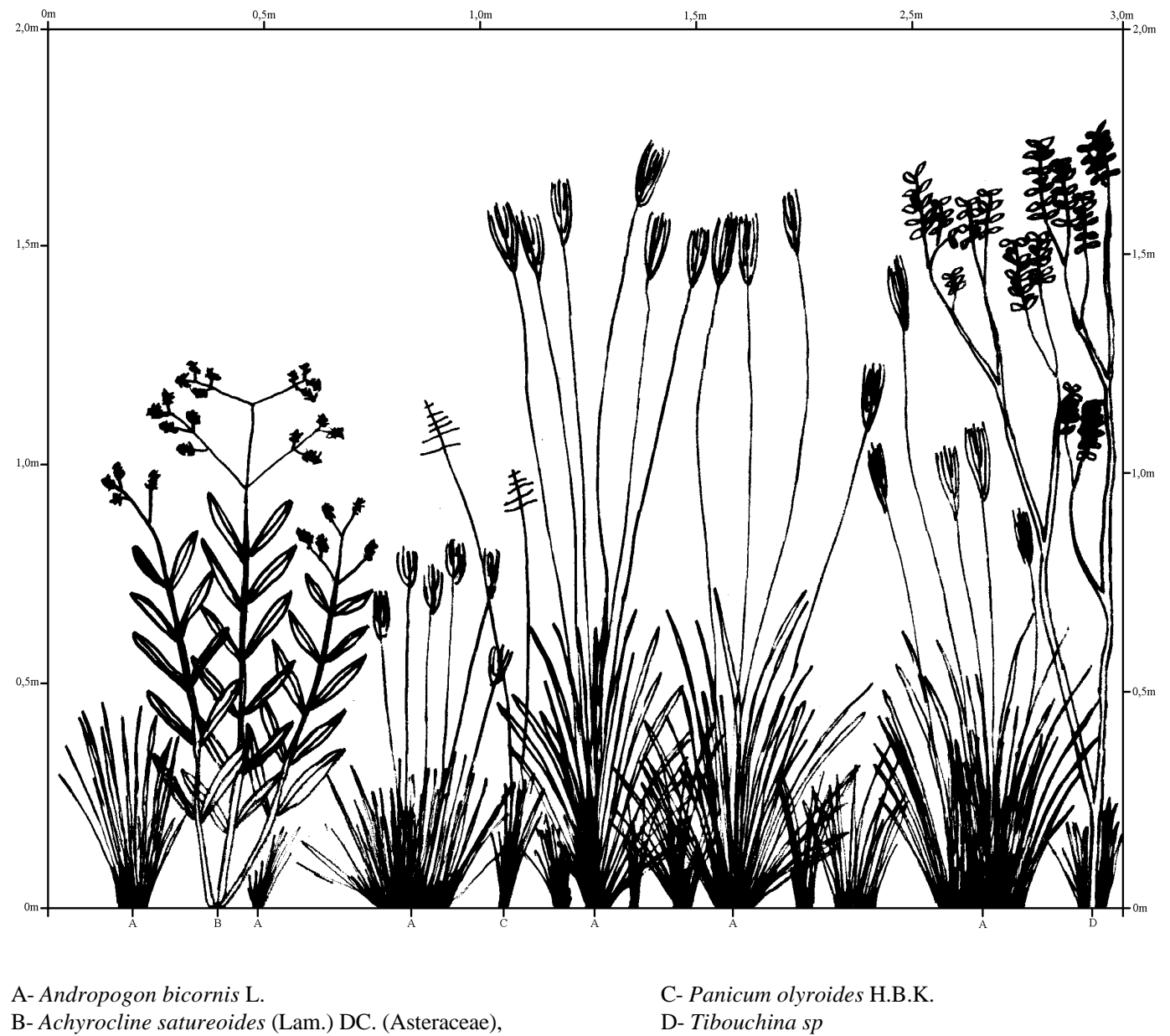

Figura 5.1 - Perfil diagrama da fisionomia campestre, neste caso sendo representada, pelo campo úmido. Estão representados indivíduos encontrados na parcela de 2,5m x 1,0m. As letras representam as espécies.

Nas encostas íngremes foi observada uma fitofisionomia de cerrado que, por suas características, foi separada das demais. É o campo sujo, denominado aqui de campo sujo de encosta. Este foi observado nas encostas mais íngremes, onde o relevo está se modificando rapidamente. Em muitos pontos o solo foi recentemente exposto devido ao forte processo erosivo. Nestas áreas, há predomínio de gramíneas, de no máximo, 0,5m de altura, com algumas arvoretas esparsas ou arbustos esparsos que não ultrapassam 2 metros. Em alguns locais, existem concentrações de Gleichenia flexuosa (Schrad.) Mett. (Gleicheniaceae). 
As fisionomias de cerrado senso lato observadas na área representam a parte do gradiente fisionômico das formas herbáceo-arbustivas até as formas florestais. Foram observadas fisionomias de campo cerrado, cerrado senso estrito, cerrado com herbáceo ralo e cerradão. Estas fisionomias compartilham espécies da flora do cerrado, porém para caracterizá-las serão apontadas apenas algumas espécies observadas que auxiliaram a identificação das mesmas.

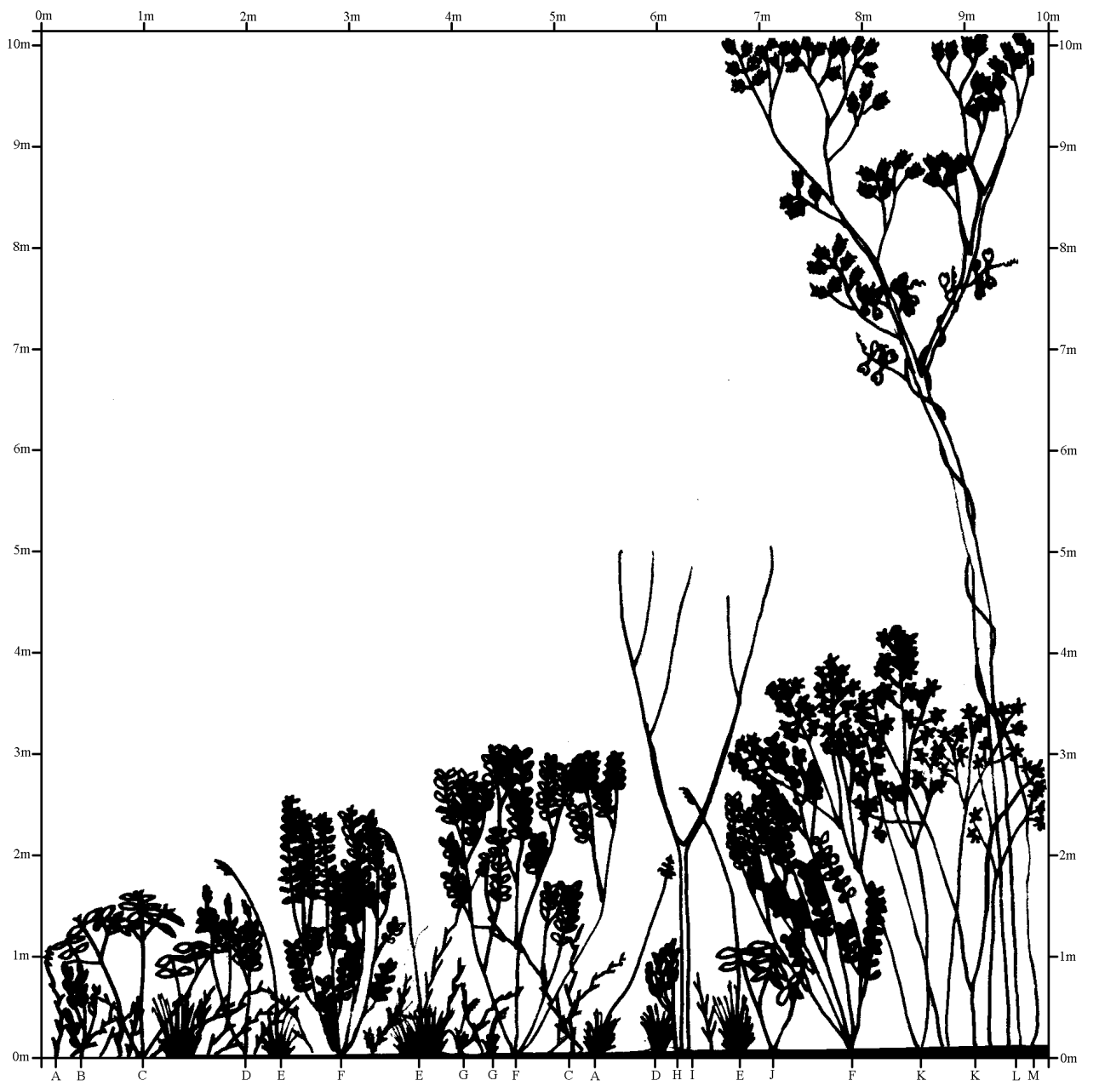
A- Melinis minutiflora Beauv.
B- Gochnatia pulchra Cabr.
C- Tocoyena formosa (C. \& S.) K. Schum.
D- Arrabidaea brachypoda (DC.) Bur.
E- Tristachya leiostachya Nees
F- Miconia albicans Triana
G- Loudetiopsis chrysothrix (Nees) Conert

H- Ouratea spectabilis (Mart.) Engl.

I- Morta

J- Qualea grandiflora Mart

K-Didymopanax vinosum (C. \& S.) Seem

L- Anadenanthera falcata (Benth.) Speg.

M- Smilax sp.

Figura 5.2 - Perfil diagrama da fisionomia de campo cerrado. Estão representados indivíduos encontrados na parcela de $10 \mathrm{~m} \times 2 \mathrm{~m}$. As letras representam as espécies. 
No campo cerrado (fig. 5.2) há predomínio de indivíduos dos componentes herbáceo e arbustivo, ocorrendo arbustos de até $2 \mathrm{~m}$ de altura, e árvores de 7-10m de altura espaçosamente distribuídas. Nesta fisionomia é possível caminhar facilmente e visualizar grandes distâncias através da vegetação. O componente herbáceo apresenta, aparentemente, maior riqueza de espécies em relação às fisionomias campestres. Geralmente os campos cerrados ocorrem em áreas adjacentes às fisionomias campestres, não muito distantes das linhas de fundo de vale da rede de drenagem. As árvores que ocorrem nesta fisionomia são, na grande maioria, Anadenanthera falcata (Benth.) Speg.

No cerrado senso estrito (fig. 5.3) existe o predomínio de formas arbustivas e arvoretas de até $5 \mathrm{~m}$ de altura. $\mathrm{O}$ dossel tem grande adensamento, dificultando a locomoção e restringindo o campo de visão. Árvores emergentes, com 7 a 10m de altura, surgem eventualmente. O estrato herbáceo-subarbustivo não é contínuo, mas recebe incidência direta de luz. Nesta fisionomia, geralmente, existe um equilíbrio na proporção da área do dossel ocupada por indivíduos dos componentes arbóreo, arbustivo e herbáceo. Esta diversificação de classes de altura resulta em dossel extremamente rugoso.

Foi observada uma fisionomia, denominada aqui de cerrado com herbáceo ralo (fig. 5.4), que possuía as características do cerradão, porém as árvores do dossel possuíam altura média por volta de 6 metros com variação de 3 a 10m. As árvores e arvoretas não chegam a formar um dossel contínuo, mas provocam razoável sombreamento nos estratos mais baixos e, conseqüentemente, um microclima mais ameno. O estrato herbáceo é ralo, com presença de muitas plântulas do componente dominante. Já se observa uma camada contínua de serapilheira. A inclusão desta categoria fisionômica tornou-se necessária por possuir características que a distinguem do cerrado senso estrito e do cerradão. Verificouse, também, que esta fisionomia ocupa, proporcionalmente às demais, uma área grande na gleba Pé-de-Gigante. 


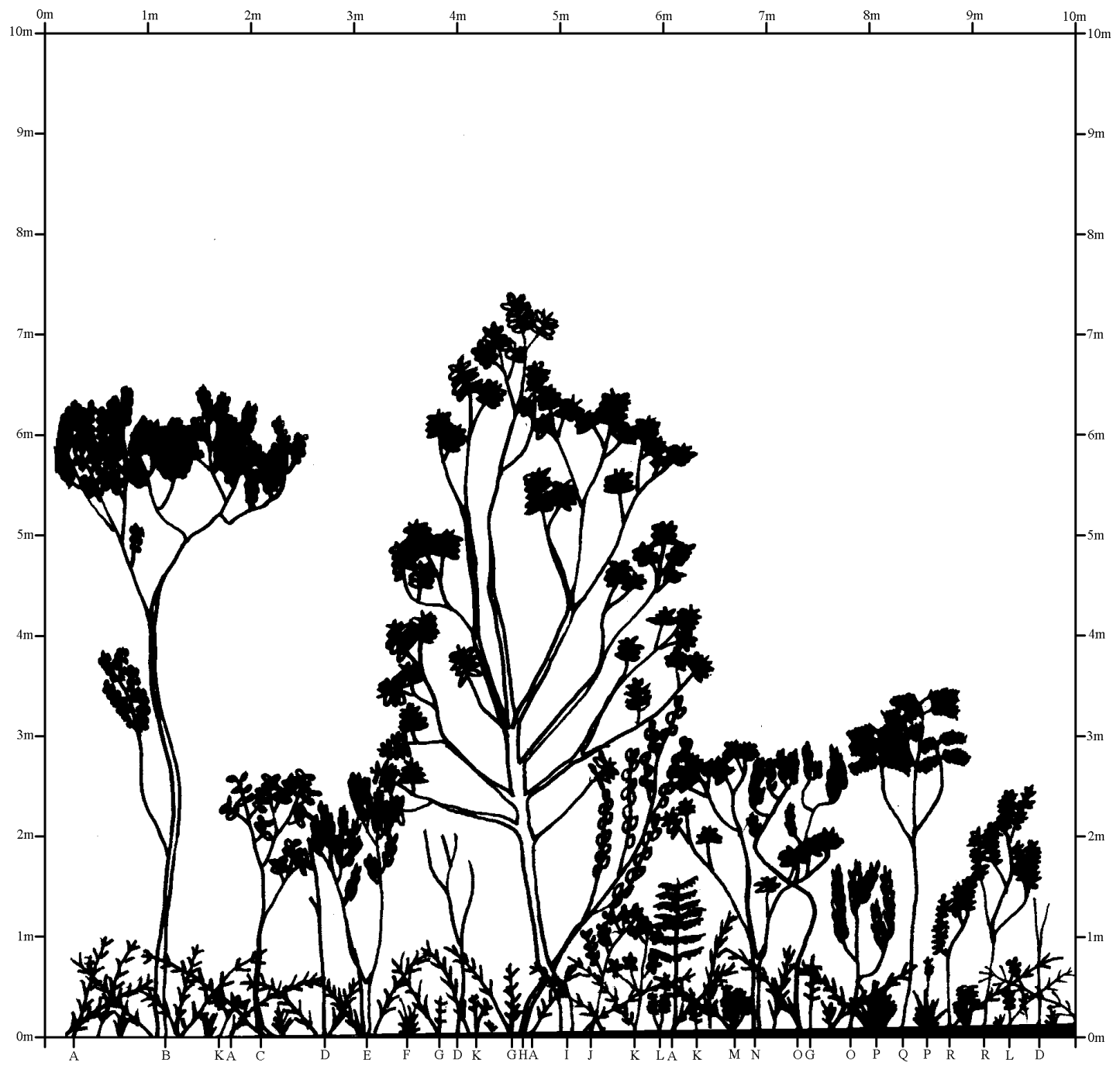

A- Rhynchospora exaltata Kunth.

H- Annona coriacea Mart.

I- Pouteria torta (Mart.) Radlk

J- Roupala montana Aubl.

N- Pouteria ramiflora (Mart.)

B-Dalbergia miscolobium Benth.

C- Qualea parviflora Mart.

D- Morta

K- Didymopanax vinosum (C. \&

O- Myrcia lingua Berg.

E- Myrcia uberavensis Berg.

F- Melinis minutiflora Beauv.

S.) Seem

L- Miconia albicans Triana

P- Ananas ananassoides (Baker)

L.B. Smith

G- Ichnanthus sericeus Hack

M- Xylopia aromatica St. Hil.

Q- Dimorphandra mollis Benth.

R-Erythroxylum tortuosum Mart.

Figura 5.3 - Perfil diagrama da fisionomia de cerrado senso estrito. Estão representados indivíduos encontrados na parcela de $10 \mathrm{~m} \times 2 \mathrm{~m}$. As letras representam as espécies. 


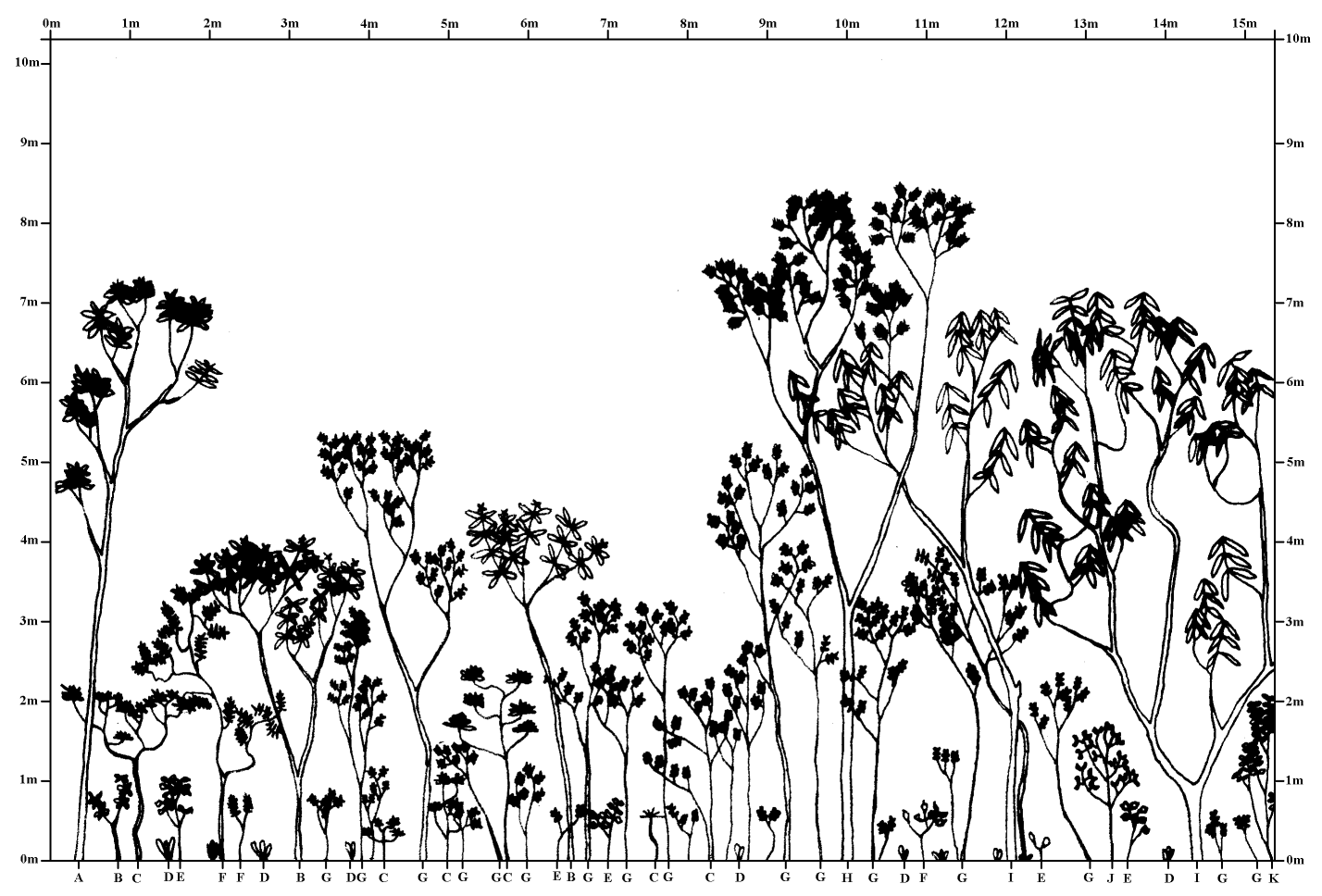

A- Pouteria ramiflora (Mart.) Radlk

B- Vochysia cinamommea Pohl

C- Aspidosperma tomentosum Mart.

G- Copaifera langsdorfii Desf.

$\mathrm{H}-$ Anadenanthera falcata (Benth.) Speg

I- Qualea grandiflora Mart

D- Anacardium humile St. Hil.

E- Roupala montana Aubl

J- Hymenaea stigonocarpa Mart

F- Erythroxylum tortuosum Mart.

K-Miconia albicans Triana

Figura 5.4 - Perfil diagrama da fisionomia de cerrado com herbáceo ralo. Estão representados indivíduos encontrados na parcela de $15 \mathrm{~m}$ x $2 \mathrm{~m}$. As letras representam as espécies.

A fisionomia de cerradão (fig. 5.5) ocorre em algumas áreas, embora não atinja o máximo grau de desenvolvimento e não se forme um dossel contínuo como poderia ser encontrado para esta fisionomia em outras áreas do estado de São Paulo. Predominam árvores com cerca de $10 \mathrm{~m}$ de altura, que provocam razoável sombreamento e microclima mais ameno nos estratos inferiores. $\mathrm{O}$ componente herbáceo é pouco desenvolvido, com a presença de muitas plântulas do estrato dominante. Pode-se observar uma camada contínua de serapilheira. 


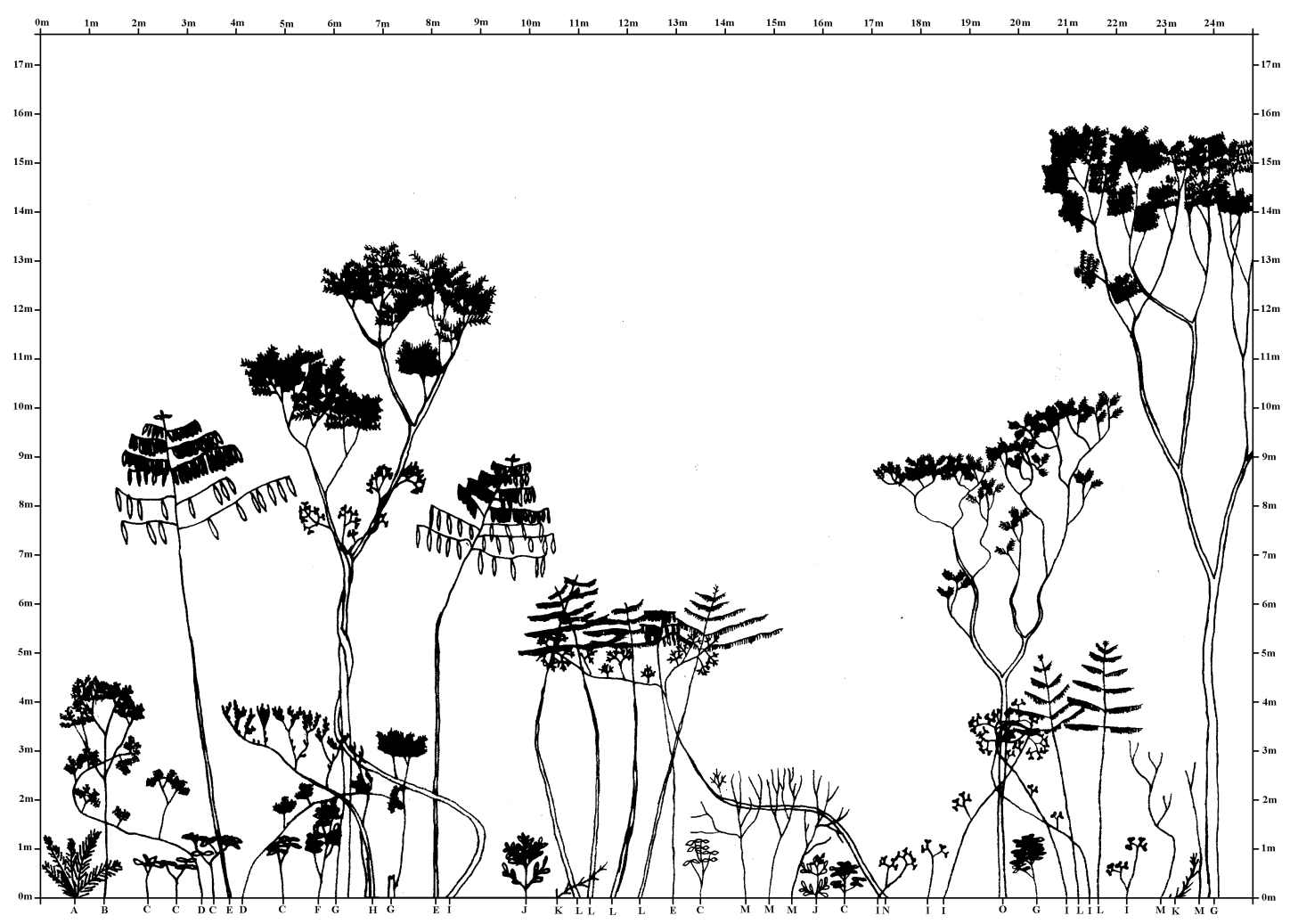

A- Syagrus loefgrenii Glass.

I- Banisteriopsis pubipetala (A. Juss.) Cuatr

B- Copaifera langsdorfii Desf

J- Couepia grandiflora (Mart. \& Zucc.) Benth

C-Alibertia macrophylla K. Schum.

D- Strychnos bicolor Prog.

E- Virola sebifera Aubl.

K- Rhynchospora exaltata Kunth.

L- Xylopia aromatica St. Hil

M- Morta

F- Bauhinia forficata Link

G- Pterodon pubescens Benth

$\mathrm{N}$ - Serjania reticulata Camb

H- Myrcia lingua Berg.

O- Anadenanthera falcata (Benth.) Speg

Figura 5.5 - Perfil diagrama da fisionomia de cerradão. Estão representados indivíduos encontrados na parcela de $25 \mathrm{~m}$ x $2 \mathrm{~m}$. As letras representam as espécies.

$\mathrm{Na}$ fisionomia da floresta estacional semidecidual (fig. 5.6.), o estrato arbóreo é superior a 10m, formando um dossel contínuo. Algumas árvores emergentes, principalmente Anadenanthera macrocarpa (Benth.) Brenam (Mimosaceae), atingem cerca de $20 \mathrm{~m}$ de altura. O subosque é dominado por Actinostemon communis M. Arg. (Euphorbiaceae). O componente herbáceo é pouco desenvolvido, formado por espécies tipicamente umbrófilas. Lianas são freqüientes e há um aumento na quantidade de epífitas em relação às fisionomias de cerrado. A camada de serapilheira é contínua ao longo de toda esta fisionomia. O microclima na parte inferior da floresta é mais úmido e mais sombreado que o observado nas fisionomias de cerrado. 


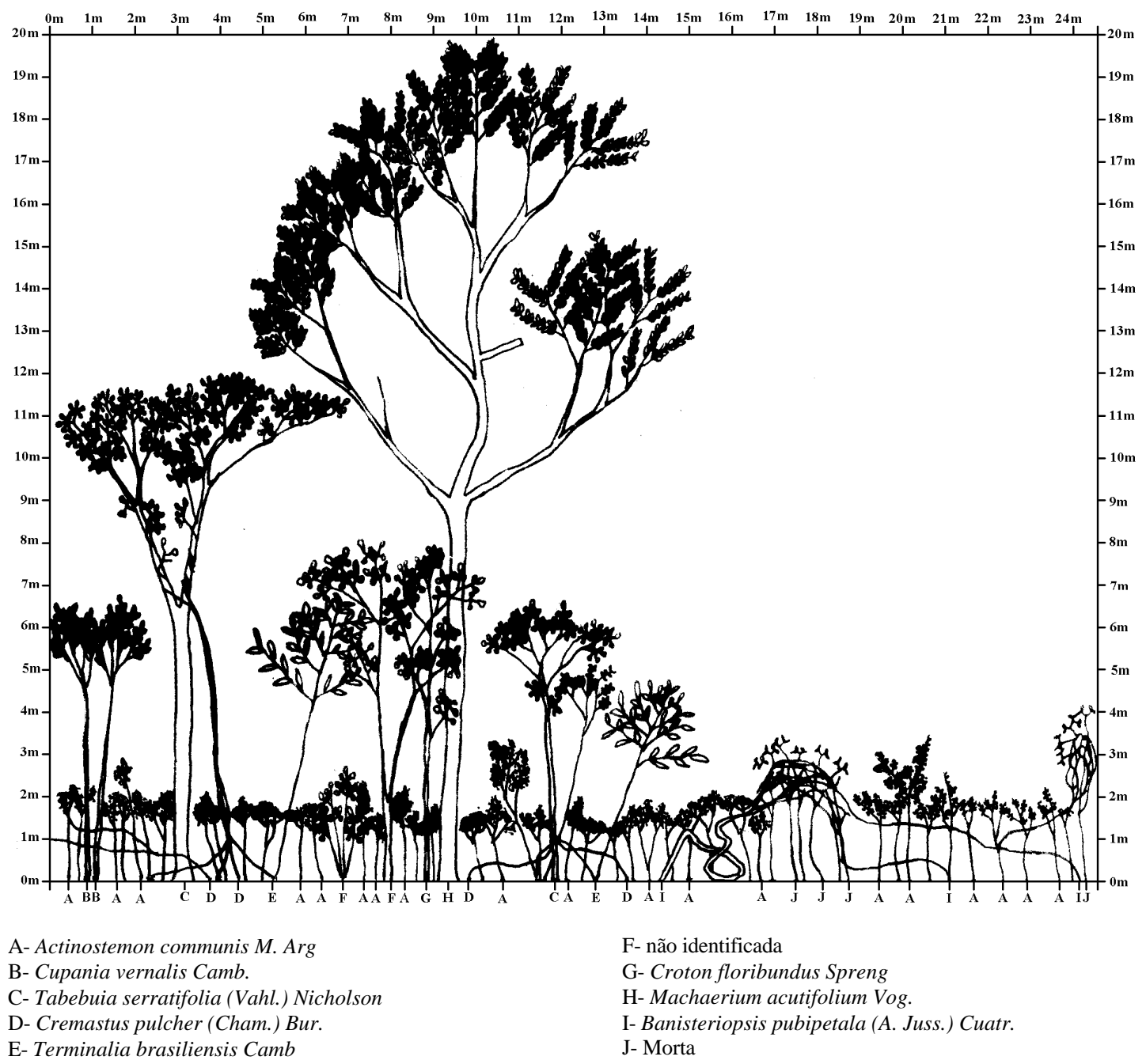

Figura 5.6 - Perfil diagrama da fisionomia de floresta estacional semidecidual. Estão representados indivíduos encontrados na parcela de $25 \mathrm{~m}$ x 2m. As letras representam as espécies.

Ocorrem também na área de estudo, as florestas ciliares. Estas florestas ocupam uma área muito pequena e restrita a proximidade do curso de água do Ribeirão Paulicéia. Nela, ocorrem espécies adaptadas ao solo permanentemente umedecido. No caso especifico da área de estudo, a floresta apresenta árvores de até 10m de altura, e muitas destas apresentam-se mortas, porém permanecem na vertical. Ocorrem também muitas lianas recobrindo o dossel.

Foram obtidos dados sobre a estrutura de algumas fisionomias por estudo fitossociológico realizado na área de estudo. Foram registados os valores de altura e área basal dos indivíduos amostrados nas parcelas. Estes parâmetros serviram para o cálculo do volume cilíndrico dos indivíduos, e para obtenção do volume da vegetação. Os indivíduos amostrados de cada fisionomia foram separados em classes de altura, e 
apresentada a distribuição do volume total e do número de indivíduos, em cada classe (fig. 5.7). O volume cilíndrico está diretamente relacionado à biomassa. Em ambas representações existe uma diminuição na proporção das classes de menor altura e aumento na proporção de classes de maior altura, partindo do campo cerrado para o cerrado senso estrito, cerradão, até a floresta estacional semidecidual. Este gradiente está relacionado com a diminuição do componente herbáceo e aumento do componente arbóreo. O gradiente de classes de altura apresentado também foi registrado nos perfis diagramas apresentados.

\section{Distribuição das Classes de Altura}

Proporção de Indivíduos

Proporção de Volume
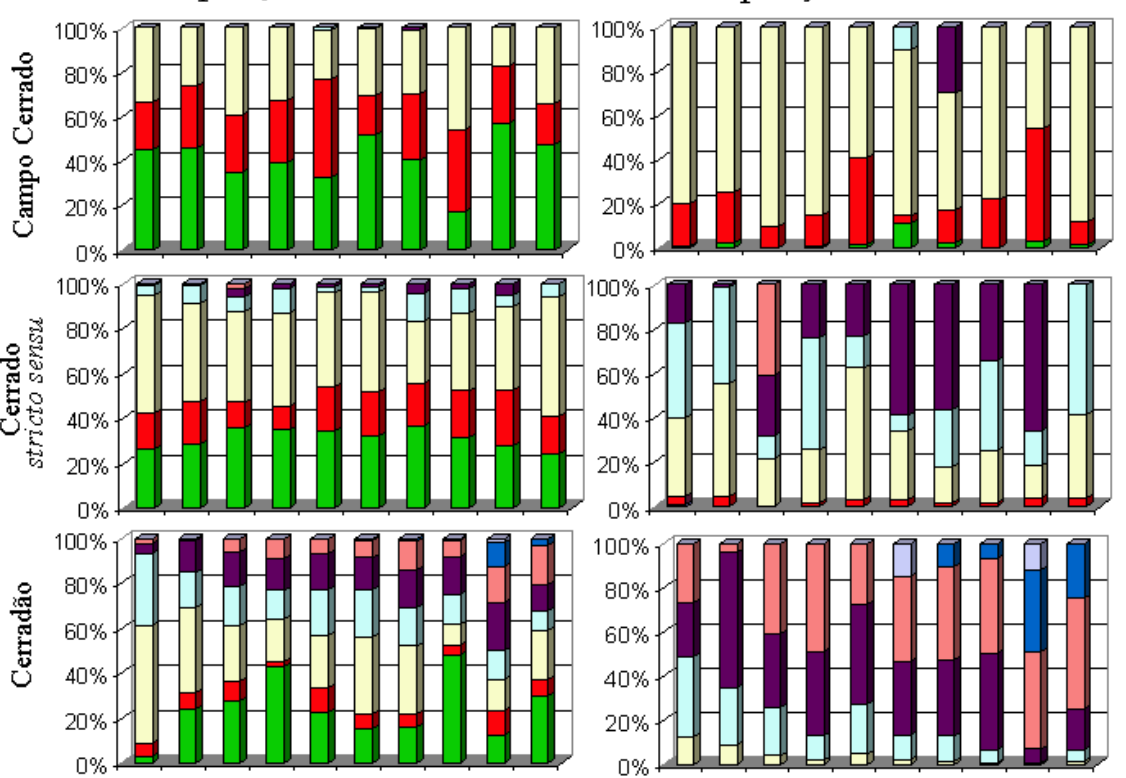

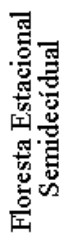
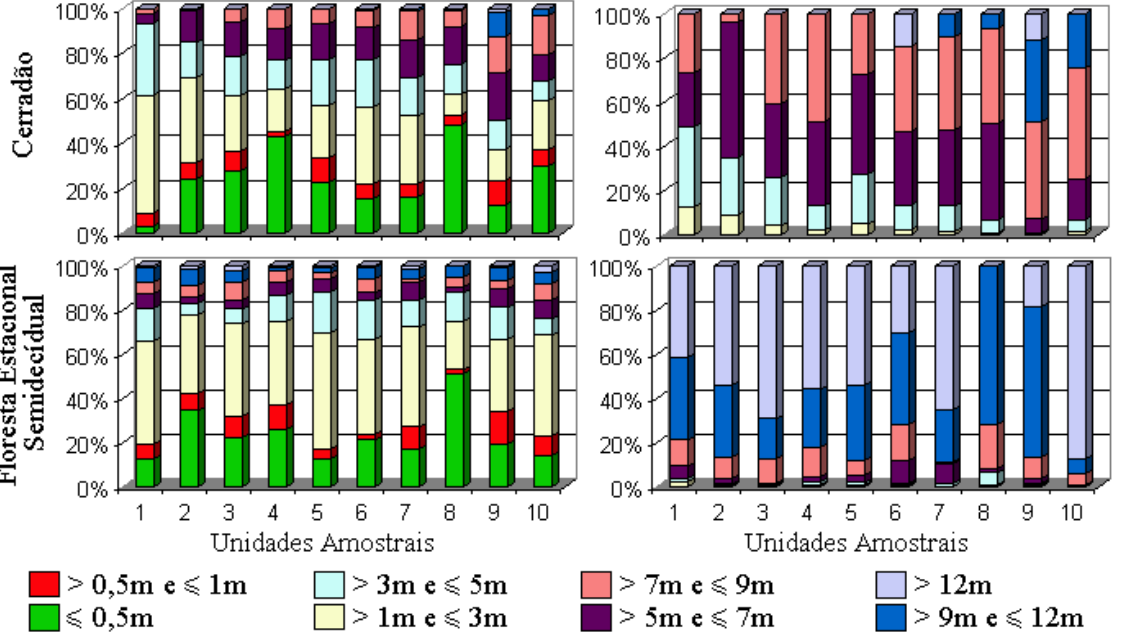

Figura 5.7- Distribuição de indivíduos e volume por classes de altura, para as fitofisionomias amostrada no estudo fitossociológico.

Os resultados obtidos no estudo piloto e a posterior checagem de campo mostraram que tipos fisionômicos diferenciados em campo tinham o mesmo IVDN na 
imagem, além disso, não se conhecia como as mudanças sazonais, que afetam as fisionomias, poderiam afetar o IVDN. Assim, foram adquiridas imagens nas datas de chuvas e de estiagem para avaliar se o IVDN poderia detectar as mudanças da vegetação nestes períodos. Ao todo foram utilizadas 5 imagens: uma no período de chuvas, 3 no período de pré-estiagem e 1 no período de estiagem.

As imagens IVDN nas cinco datas, apresentadas na figura 5.8. indicam a variação da densidade de vegetação (quantidade de folhas verdes), vermelho representa baixo IVDN e o verde alto IVDN. Baseando-se no mapa de das fiotofisionomias da figura 3.5.3. (Bitencourt et alii, 1997), a região central, onde ocorrem fisionomias campestres, tem em todas as épocas IVDN baixos e as partes mais externas, com maior desenvolvimento do componente arbóreo com tons esverdeados. O mês de agosto é o mais seco (fig. 3.1.2.) e que apresenta os menores IVDNs (tons amarelos); em contrapartida, o mês de janeiro é o mais úmido (fig. 3.1.2.), com os maiores IVDNs (tons verdes).

$\mathrm{Na}$ primeira análise da distribuição espacial das fisionomias (mapa das fitofisionomias do estudo piloto), uma mesma fisionomia apresentou classes de IVDN distintas em diferentes datas, então tornou-se imprescindível estabelecer qual o intervalo de IVDN sazonal para cada fisionomia. Assim foi realizado o detalhamento do mapa inicial, com o objetivo de delimitar as áreas de maior probabilidade de ocorrência das fisionomias. O procedimento adotado para este fim, foi o da incorporação das informações obtidas em campo e características específicas dos ambientes onde ocorrem estes tipos de vegetação. Assim, foram separadas outras fitofisionomias que na primeira análise foram consideradas como fisionomias de cerrado, ou as de cerrado que apresentavam peculiaridades que justificassem a separação como outra classe. Para obter maior certeza da delimitação, foram sobrepostas as informações das transeções sobre o morro e checados os resultados com observações e registros da posição de ocorrência das fisionomias em outros locais da gleba. 

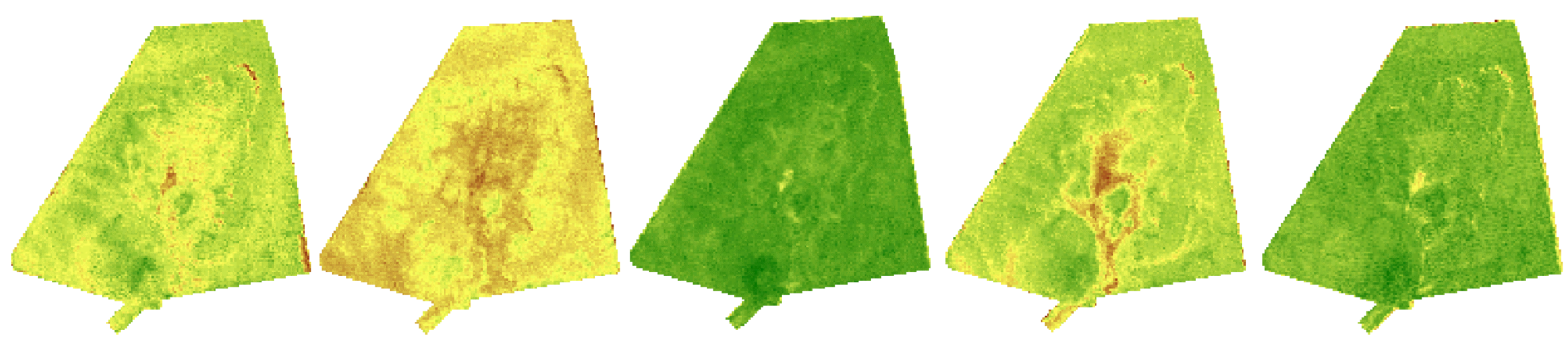

Índice de Vegetação Diferença Normalizada

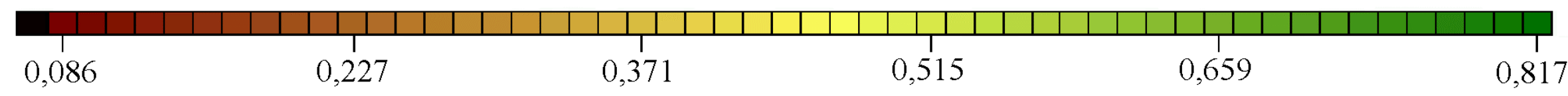

Figura 5.8. - Imagens IVDN de julho de 1995, agosto de 1995, janeiro de 1996, julho de 1996 e junho de 1997. 
As fisionomias foram analisadas em campo quanto à distribuição espacial. Esta análise da vegetação foi feita com os dados obtidos ao longo das transeções sobre o morro que ocorre na parte central da área de estudo. Esta área foi escolhida, pois já existia a hipótese da distribuição da vegetação estar relacionada ao relevo e porque possui todo o gradiente de fisionomias de cerrado.

Os perfis foram percorridos no campo com o registro descrição da cobertura vegetal ao longo da transeção (tab. 10.4.) e da iluminação relativa (5 pontos abaixo do dossel e 5 pontos acima do dossel) e da descrição da fitofisionomia, em intervalos de 30m na transeção Oeste para Leste e de 50m na transeção de Norte para Sul. As medidas das distâncias entre os pontos foram feitas com uma trena. Também foram registrados posicionamentos com o GPS ao longo da transeção.

Com as coordenadas dos pontos obtidos com o GPS na transeção, os percursos realizados sobre o morro foram sobrepostos nas imagens IVDN nas 5 datas (fig. 5.9.). Assim, foram extraídos das imagens os IVDN correspondentes as posições no terreno onde foram realizados as transeções (descrição das fisionomias e das medidas de iluminação).

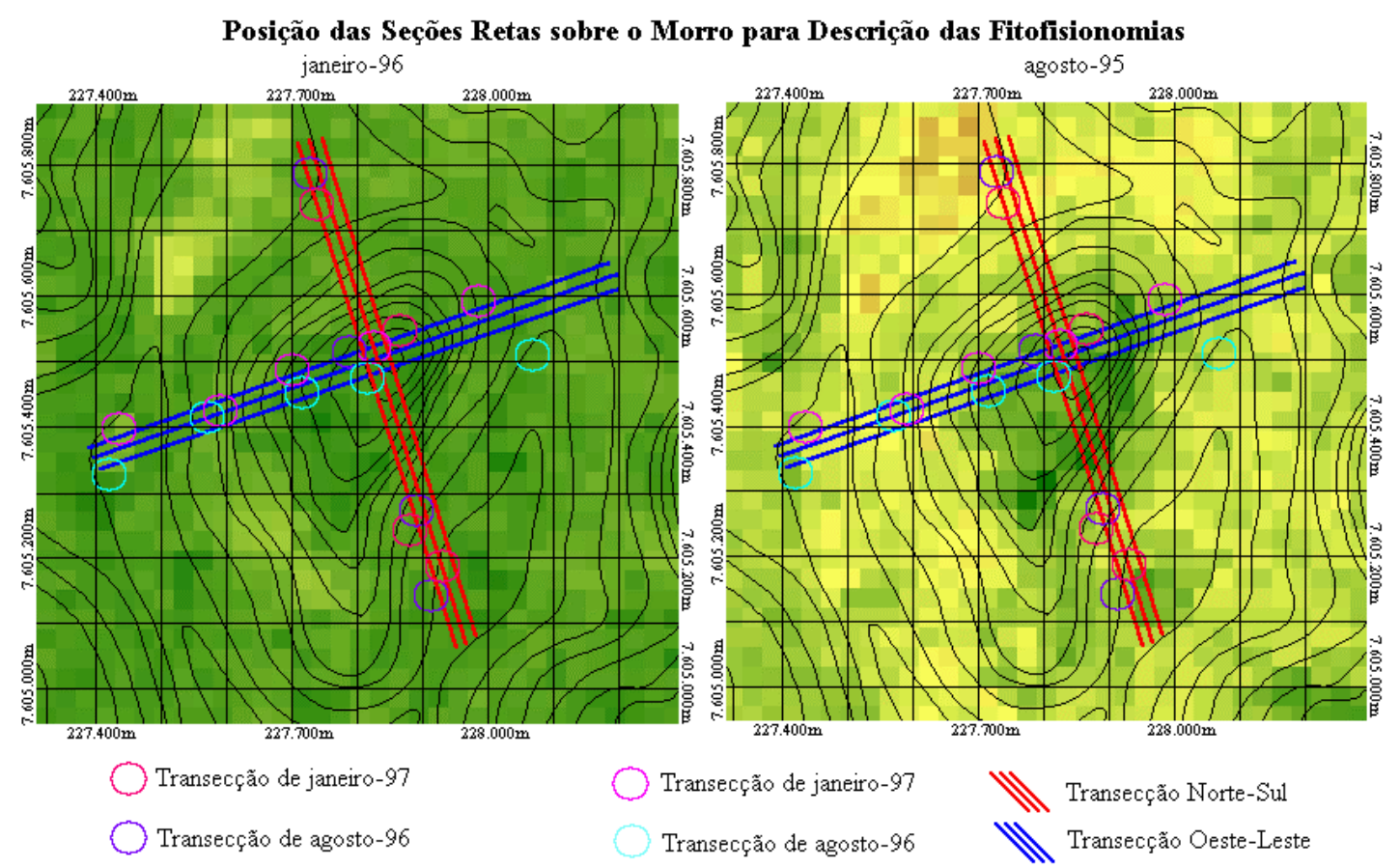

Figura 5.9. - Posição das transeções sobre o morro, exemplificada, nas imagens de agosto de 95 e de janeiro de 1996. 
Para que os registros das transeções pudessem ser coincidentes com as imagens IVDN, a distância medida no campo foi ajustada com a distância da superfície do MDT. Este ajuste é necessário pois a medida de distância nas imagens é uma projeção horizontal da superfície (ex. terrenos acidentados têm área subestimada). Foi utilizada a imagem do MDT para obtenção dos valores de distância superficial, isto porque esta imagem tem melhor resolução espacial ${ }^{9}$ tanto horizontal quanto vertical. Esta imagem tem resolução de $10 \mathrm{~m}$ x 10m, assim com os valores de variação de elevação (cateto) e projeção da distância (cateto) foi calculada a distância superficial (hipotenusa). Sobre esta escala de distância foram sobrepostos os registros de campo. Desta forma, a cada cela da imagem foi atribuído um valor do registro de campo. Cada 3 pontos desta imagem foram registrados sobre um ponto da imagem com resolução de $30 \mathrm{~m}$ x 30m. Desta forma os registros de campo foram sobrepostos nas imagens IVDN (tab. 10.5.). Assim, os valores de IVDN puderam ser relacionados aos dados obtidos em campo: medidas de iluminação relativa e descrição das fisionomias nas transeções (fig. 5.10.).

Os IVDN extraídos das posições das transeções serviam para definir intervalos, que correspondem as fitofisionomias observadas em campo, que serviram para classificar as imagens. Porém, algumas fitofisionomias observadas na gleba não foram amostradas nas transeções sobre o morro. Estas fitofisionomias foram delimitadas também com a utilização das informações do meio físico, ou seja, a partir dos dados digitalizados e incorporados ao sistema de informações geográficas. $\mathrm{O}$ objetivo de delimitar estas áreas é evitar que elas possam ser consideradas como fisionomias de cerrado, no momento da reclassificação das imagens.

A partir da posição das transeções sobre o morro, foram extraídos os valores médios de IVDN para análise das fisionomias. Notou-se que a imagem de julho de 1996 foi a que apresentou a capacidade de separar o maior número de fisionomias (campo limpo, campo cerrado, cerrado senso estrito, e o cerrado com estrato herbáceo ralo). Porém, a imagem de agosto apresenta maior capacidade de separar a fisionomia de cerradão, isto é, maior diferença de IVDN entre fisionomias adjacentes. A figura 5.11. mostra a variação do IVDN médio de cada fisionomia ligadas por 
linhas contínuas, quanto maior a inclinação da reta maior a diferença de valores entre as fisionomias.

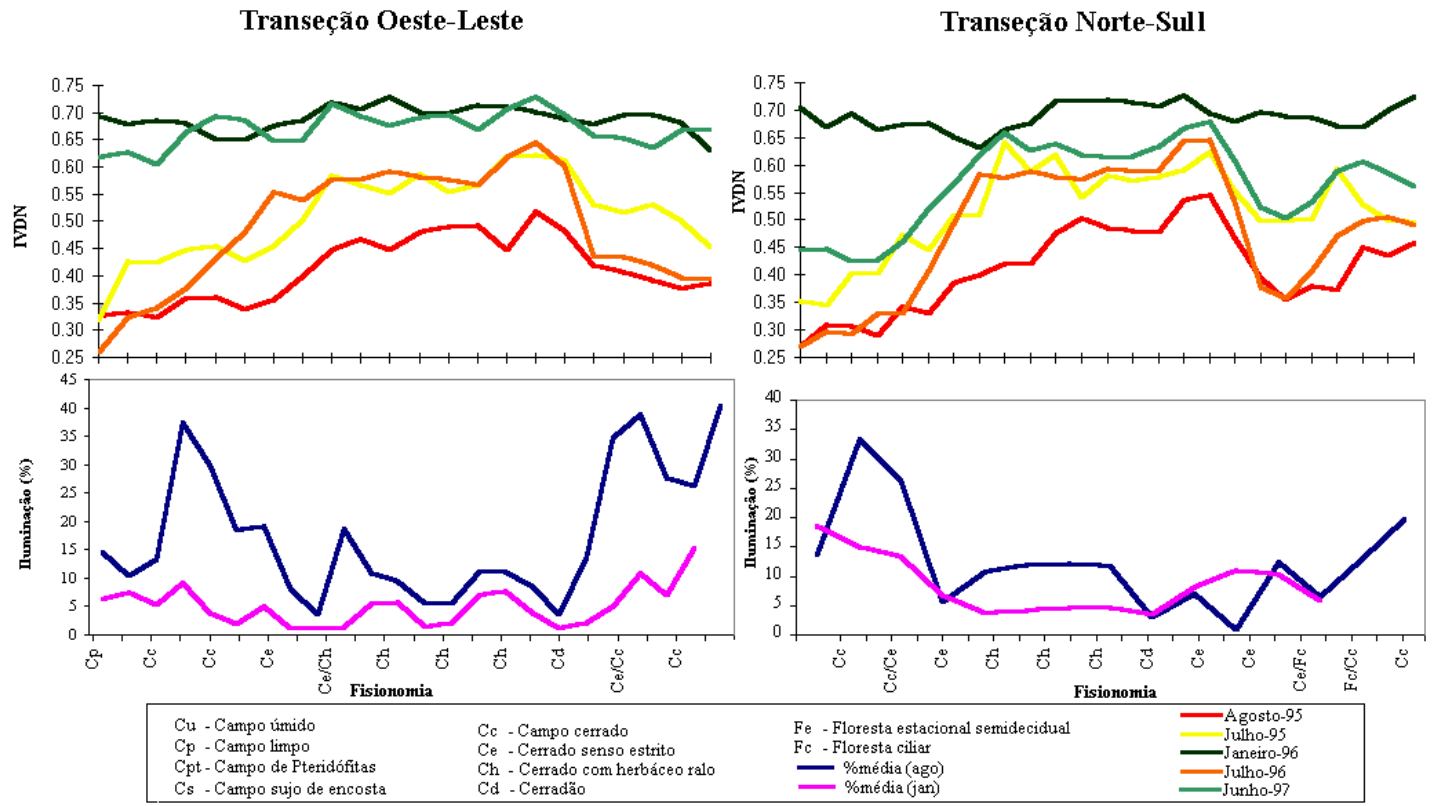

Figura 5.10. - Variação do IVND médio, nas cinco datas das imagens, nas transeções Norte-Sul (acima) e Oeste-Leste (abaixo); os IVDN estão relacionados com os respectivos dados obtitidos em campo: iluminação relativa e descrição dos tipos fisionômicos.

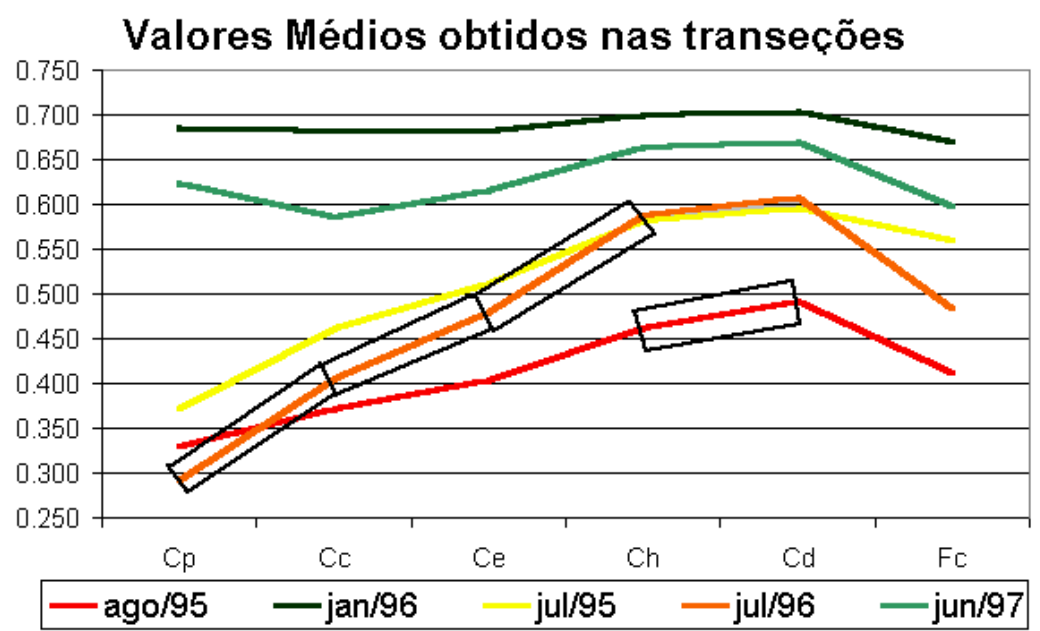

Figura 5.11. - Valores do IVDN médio para cada fisionomia descrita na transeção sobre o morro. As caixas sobre as retas indicam os intervalos e as datas utilizadas para a separação da área de ocorrência da fisionomia.

As imagens foram classificadas segundo as informações obtidas no campo com as transeções sobre o morro. Nesta ocasião foram feitas as descrições das fisionomias e registrados os posicionamentos com o GPS. As transeções foram sobrepostas às 
imagens IVDN das cinco datas, onde se identificou os IVDN correspondentes a cada fisionomia identificada em campo. Os valores médios de cada fisionomia nas cinco datas foram comparados com os valores médios das demais fisionomias. A data que apresentou o valor médio da fisionomia com maior diferença em relação as demais, foi escolhida para separar a área de ocorrência da fisionomia. A imagem, na data escolhida para uma fisionomia, foi então classificada com o intuito de separar a área da imagem que continha o mesmo intervalo obtido para a mesma fisionomia descrita na transeção. Assim, foram sendo uma a uma separadas as áreas de ocorrência para cada fisionomia.

Foram observadas em outras partes da área de estudo (geralmente pequenas manchas) fisionomias associadas às fisionomias de cerrado. Estas fisionomias não ocorriam no morro e não foram amostradas nas transeções. Estas fisionomias associadas foram posicionadas com o GPS. Conhecendo a posição destas na área de estudo, foram utilizadas informações adicionais, as das imagens IVDN, que consideravam características do ambiente onde ocorrem estas fisionomias. O objetivo de determinar as áreas de ocorrência destas fisionomias foi evitar que pudessem ser incluídas como fisionomias de cerrado. A floresta ciliar, por exemplo, apresentou intervalo de valores coincidentes com fisionomias de cerrado, e as informações do relevo foram importantes para separá-la das demais.

A seguir estão apresentados os intervalos e os tipos de dados utilizados para a separação das áreas de ocorrência de cada fitofisionomia encontrada na gleba, e que gerou o mapa das áreas de maior probabilidade de ocorrência (fig. 5.12).

Campo limpo (imagen de julho de 96) - O intervalo foi do valor mínimo até 0.34874266. Neste caso estão sendo incluídas, neste intervalo, as fisionomias campestres que não foram observadas nas transeções sobre o morro (campo úmido, campo de pteridófitas e campo de encosta).

Campo úmido (relevo e imagen de julho de 1995) - Foi separado dos demais, incorporando informações do MDT. A posição foi obtida com o GPS e a delimitação foi realizada pela linha de cota, que no caso do campo úmido é de $630 \mathrm{~m}$ no mapa 
topográfico (uma pequena área plana onde ocorrem alagamentos anuais). Assim foi possível separar a área de provável ocorrência do campo úmido. Porém, a planície incluía na sua parte norte uma mancha com a ocorrência de campo de pteridófitas. A separação foi realizada com a utilização da imagem do mês de julho de 1995. Nesta data, as fisionomias apresentaram maior diferença de valores e maior contraste. Então foram separadas duas classes de intervalo de IVDN de 0.21 até 0.36 para o campo úmido e de 0.36 até 0.56 para o campo de pteridófitas. Assim foram separadas as áreas de provável ocorrência destas classes.

Campo sujo de encosta (imagem de julho de 1996 e relevo) - Apresentou intervalo de IVDN semelhante ao das fisionomias campestres e também do campo cerrado. A ocorrência desta fisionomia é no entanto restrita as encostas íngremes, e foi relativamente fácil delimitar a área de ocorrência. Foram utilizados os intervalos de valores das fisionomias campestres, e de campo cerrado, e também as informações da posição geográfica das encostas íngremes na área de estudo (obtidas pelo mapa topográfico).

Campo cerrado, cerrado senso estrito e cerrado com herbáceo ralo (imagem de julho de 1996) - Com as informações obtidas nas transeções sobre o morro, foi possível separar na imagem de julho de 1996 as seguintes fisionomias: o campo cerrado com o intervalo de 0.348 a 0.443 , o cerrado senso estrito com o intervalo de 0.443 a 0.534 , e o cerrado com herbáceo ralo de 0.534 até o valor máximo. $\mathrm{O}$ intervalo que separou a última fisionomia incluía a fisionomia do cerradão, da floresta estacional semidecidual e a mata ciliar. Estas fisionomias foram separadas com a utilização de informações adicionais.

Cerradão (imagem de agosto de 1995) - O intervalo para de valores do cerradão foi obtido com as informações das transeções sobre o morro e com a imagem de agosto de 1995 (apresentou maior contraste em relação ao cerrado com herbáceo ralo). O intervalo de IVDN foi de 0,477 até o valor máximo. No mês de agosto, este intervalo ainda continha a floresta estacional semidecidual. 
Floresta estacional semidecidual (imagem de janeiro de 1996) - A imagem de janeiro de 1996 foi utilizada para delimitar a floresta estacional semidecidual. A posição geográfica desta fisionomia foi registrada em campo, pois ocorre em uma única mancha contínua. Então a imagem de janeiro foi testada para os intervalos de IVDN, mínimo de 0,70 até 0,80 (variando o intervalo de IVDN de 0,01 em 0,01) e máximo igual ao máximo da imagem. $\mathrm{O}$ resultado destas classificações foi avaliado quanto à posição dos pontos com estes intervalos. O intervalo de 0,75 até o máximo para a imagem de janeiro de 1996, foi o que melhor separou a de ocorrência de floresta estacional semidecidual.

Floresta Ciliar (imagem de julho de 1996 e relevo) - A floresta ciliar foi separada a partir dos dados obtidos nas transeções sobre o morro e com a imagem de julho de 1996, obtendo-se o intervalo de 0,445 até o máximo (separação das fisionomias campestres). Este intervalo é semelhante ao de outras fisionomias. Foram então, utilizadas informações adicionais para a delimitação desta. As informações da topografia foram utilizadas para delimitar a área que incluía todos os pontos com distância inferior a 40m do curso de água (rede de drenagem onde ocorre afloramento superficial de água). A partir daí, com estas informações foi possível delimitar esta classe. 


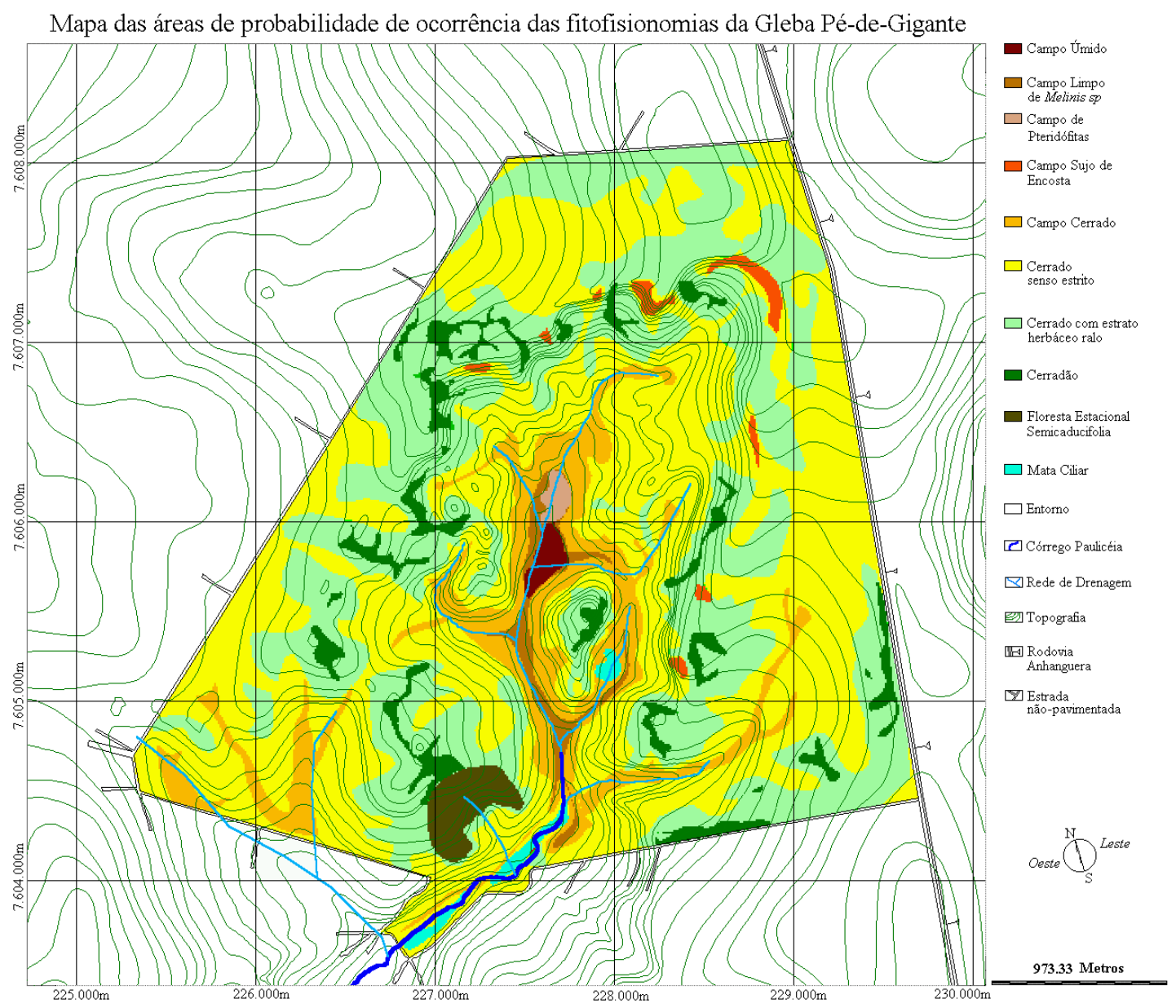

Figura 5.12. - Mapa das áreas de maior probabilidade de ocorrência das fisionomias considerando a sazonalidade (1995-1996).

O fluxograma apresentado na figura 5.13. mostra de forma resumida o método utilizado para a separação das áreas de ocorrência das fisionomias. Na etapa inicial do trabalho foi utilizada apenas uma imagem que foi classificada por método de fatiamento do intervalo de valores máximo e mínimo da imagem em classes iguais. Este método baseia-se na premissa de que cada classe reconhecida em campo pode ser separada com um único intervalo de valores. Após a checagem de campo foi possível identificar os tipos de fisionomias de cerrado e os locais ocorrência das fisionomias na gleba. No resultado preliminar, duas classes identificadas em campo possuíam o mesmo intervalo de IVDN, e existia a incerteza em relação a delimitação das áreas de ocorrência de cada fisionomia. Foram então obtidas imagens em diferentes estações do ano e foram obtidos dados de campo sobre a vegetação em duas épocas do ano. Assim, utilizando outro método de classificação foram 
determinadas as áreas de ocorrência das fisionomias. O método considerou as informações de campo para obter os intervalos da data de maior separabilidade, que foi então aplicado para classificar toda a imagem. Dessa maneira, a imagem na melhor data para uma dada fisionomia, foi classificada do modo a separar a área de ocorrência da fisionomia do restante da área na imagem (demais fisionomias). Para algumas fisionomias foram consideradas também informações sobre o meio físico sobre o qual ocorriam (a partir de dados cartográficos). Para diferenciar as fisionomias em campo foram utilizados perfis diagramas com a estrutura da vegetação e, no caso de algumas fisionomias associadas, informações florísticas que as diferenciavam das de cerrado.

Sobrepondo o mapa de ocorrência das fisionomias (fig. 5.12) nas imagens das diferentes datas, foi extraída a média e o desvio padrão das imagens: IVDN, na faixa do vermelho, infravermelho próximo e infravermelho médio (tab. 10.7.).

A variação dos valores médios das fitofisionomia em cada data, mostrou uma tendência comum, quanto maior a participação do componente arbóreo na fisionomia (que indica estar relacionado à quantidade de biomassa verde) maior o IVDN (fig. 5.14.). Os valores de IVDN obtidos, na gleba Pé-de-gigante, para a fisionomia de campo cerrado (de 0.354 em agosto até 0.671 em Janeiro) foram semelhantes aos dados obtidos por Bitencourt-Pereira (1986) em campos cerrados do Brasil central (0,310 a 0,469). Os dados obtidos por Santos 1988 em cerrado senso estrito foram comparáveis ao obtidos neste trabalho, o autor analisou duas épocas do ano apresentando o mesmo padrão sazonal observado neste trabalho (de 0,511 a 0,550 no período de estiagem e de 0,551 a 0,619 no período de pré-estiagem). Os dados obtidos por França (1994) mostram o mesmo tipo de variação do IVDN ao longo do ano (meses de alta pluviosidade maior IVDN, diminuição no período de estiagem), porém os IVDN obtidos, em todas as épocas do ano, para campo limpo de cerrado $(0,13$ a 0,25$)$, foram inferiores aos obtidos na gleba Pé-de-Gigante $(0.343$ a 0.670$)$. 

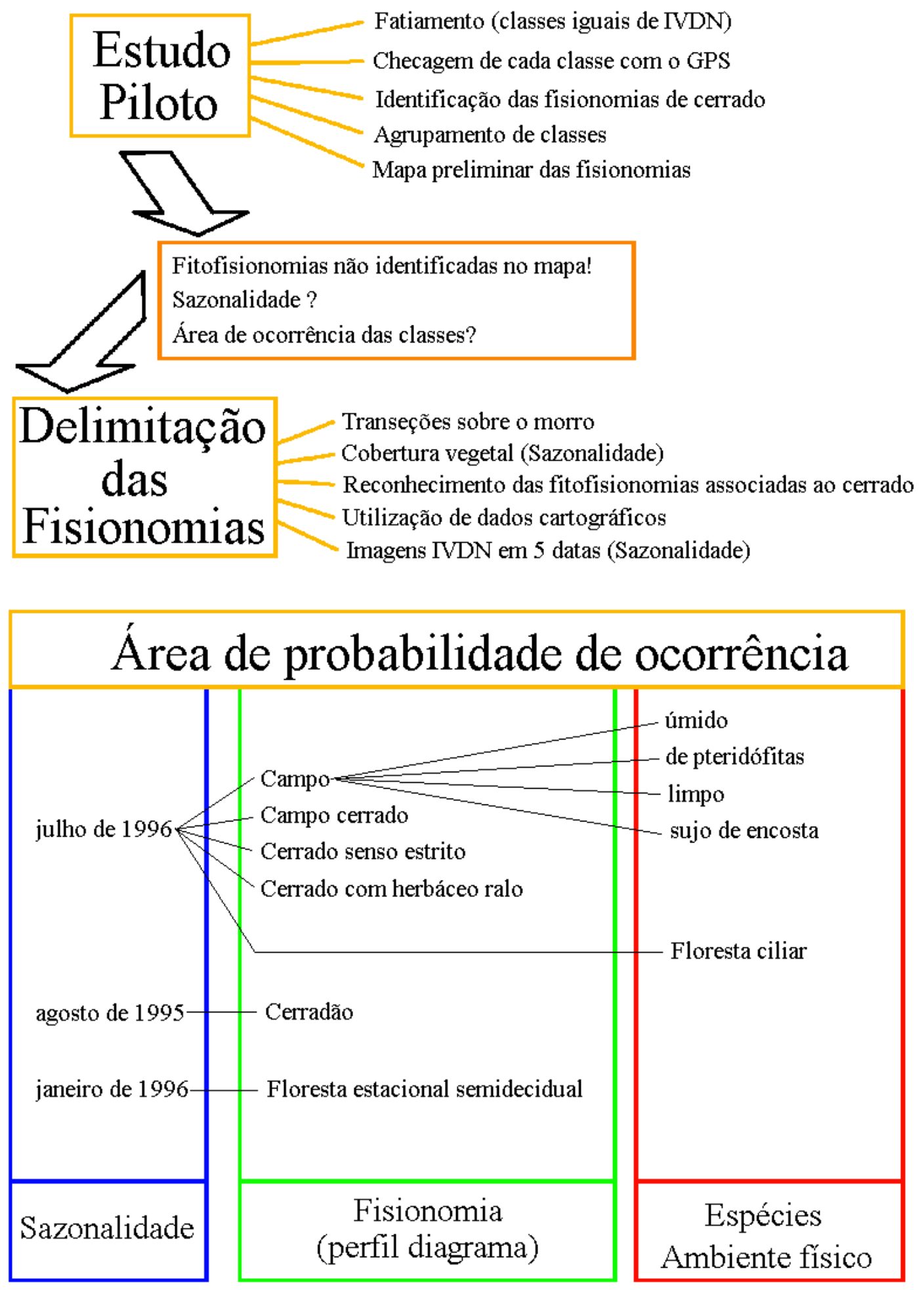

Figura 5.13. - Fluxograma resumido das atividades realizadas para a delimitação das áreas de ocorrência das fitofisionomias na área de estudo. 
Uma possível explicação para as diferenças observadas em relação a França (1994) é decorrente das diferenças no tipo de alvo; no caso do Parque de Emas geralmente ocorrem campos com predomínio de Tristachya leiostachya Nees e na gleba Pé-de-gigante campos com predomínio Melinis minutiflora Beauv. Outra explicação é decorrente do tipo de sensor utilizado, o AVHRR do Satélite NOAA. Os dados obtidos por Tucker et alii (1985), com o mesmo sensor, para todos os tipos vegetais do continente africano (incluindo desertos até as florestas chuvosas equatoriais) foram inferiores aos valores encontrados para as fisionomias florestais da gleba Pé-de-gigante. Embora o autor tenha estudado vegetação distinta da encontrada na reserva, em nenhuma época do ano qualquer um dos tipos florestais amostrados atingiram IVDN igual 0.6. No trabalho de Tucker et alii (1985), o maior valor de IVDN corresponde às florestas úmidas da África central no período chuvoso. Os valores máximos de IVDN obtidos na gleba Pé-de-Gigante no período de chuvas para a floresta estacional semidecidual ultrapassou este valor atingindo o IVDN médio de 0.75 (tab. 10.7.). Esta relação entre o IVDN obtido pelo AVHRR e o TM Landsat apresentada aqui é especulação. Há necessidade de ser melhor estudada, para testar a hipótese. 


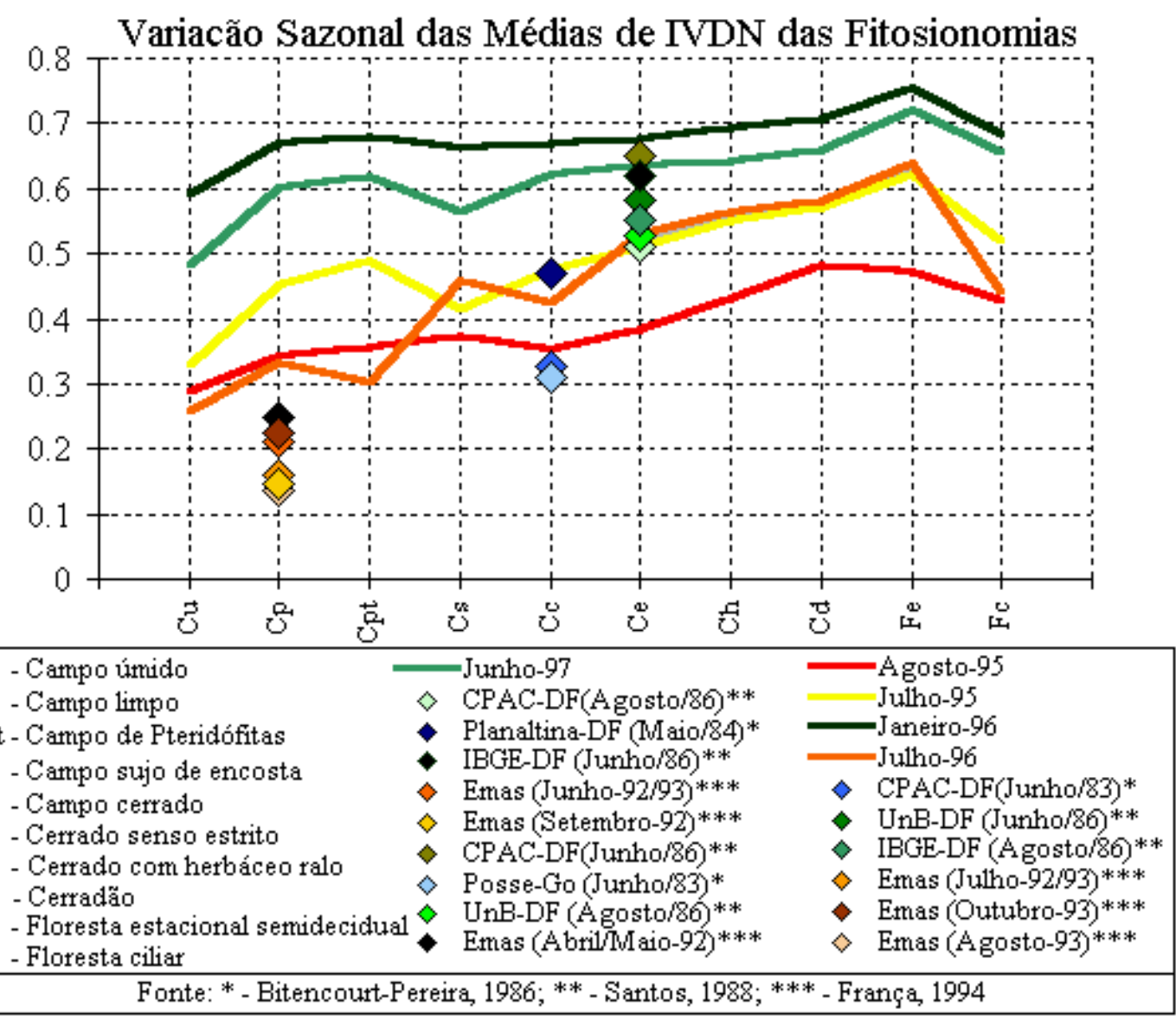

Figura 5.14. - Variação do IVDN médio obtido nas fitofisionomias da gleba Pé-de-Gigante (extraído das áreas de ocorrência) e os IVDN médios obtidos por França (1994) Santos (1988) Bitencourt-Pereira (1986). 
A variação do IVDN ao longo do ano está muito relacionada às condições do tempo, principalmente com o parâmetro pluviosidade mensal acumulada, como foi mencionado por França (1994). Quando as condições de pluviosidade são altas (temperaturas acima de 25 graus, fotoperíodo alto) como acontece nos meses de janeiro e fevereiro na área de estudo, a vegetação encontra-se em pleno desenvolvimento e aumento da biomassa verde. Provavelmente, com as maiores taxas de produtividade são encontrados os maiores IVDN para as fitofisionomias. No mês de agosto ocorre a estiagem com menor pluviosidade, baixo fotoperíodo, alta amplitude térmica e com possibilidades de ocorrência de geadas; nesta época a biomassa verde é baixa e o IVDN é proporcionalmente baixo (fig. 5.14).

As variações dos parâmetros meteorológicos são acompanhadas por alterações nas plantas em geral. Geralmente nos períodos que precedem a uma época de estresse, as plantas perdem parte da biomassa fotossinteticamente ativa, por senescência e abcisão foliar. Em outros casos a perda desta biomassa pode ser decorrente de uma geada, por morte destes tecidos. As fitofisionomias observadas neste trabalho apresentaram tendência semelhante; todas perdem parte da biomassa verde, mas em taxas diferenciadas.

As fisionomias de cerrado senso lato apresentaram um gradiente: as fisionomias campestres apresentaram as maiores variações IVDN entre o período seco e úmido (fig. 5.14) e a diferença diminui gradualmente até o cerradão: o campo úmido variou de 0,288 em agosto 95 à 0,594 em janeiro 96, diferença de 0,306; o campo limpo com diferença de 0,327; o campo de Pteridium de 0,323; o campo sujo de encosta de 0,292; o campo cerrado de 0,298; o cerrado senso estrito 0,296; o cerrado com herbáceo ralo de 0,261; e o cerradão de 0,223. Esta variação está plenamente associada ao gradiente fisionômico e ao princípio floresta-ecótono-campo dos cerrados senso lato. A medida que diminui a participação do componente herbáceo diminui a variação do IVDN entre as duas épocas. Como foi apontado por Batalha (1997), a deciduidade e morte dos ramos de brotamento dos indivíduos anuais atinge o máximo em agosto. 
Nos campos, onde o componente herbáceo é predominante, praticamente não existem folhas verdes em agosto (perda total da biomassa verde). Nas fisionomias campestres de cerrado ocorrem freqüentemente espécies com raízes profundas e que podem, durante a estiagem, manter algumas folhas verdes por um período mais prolongado que as espécie anuais. Nos meses que precedem a estiagem o componente herbáceo apresenta maior perda da biomassa verde em relação ao componente arbóreo, o que pode ser observado comparando as fisionomias com maior participação do herbáceo com aquelas que tem menor participação do herbáceo nos meses junho e julho na figura 5.14.

Nas fisionomias florestais o predomínio é do componente arbóreo, as plantas deste componente geralmente apresentam raízes profundas e perda parcial da biomassa verde. A variação do IDVN destas fisionomias é menor, entre a época de chuvas e de estiagem. No período de pré-estiagem a variação do IVDN entre as fisionomias florestais e as campestres é maior, seguido pelo período de estiagem, e o período de chuvas é o que apresenta menor variação entre as fisionomias. Observando a figura 5.14. no trecho entre campo cerrado até o cerradão (fisionomias de cerrado senso lato), é possível perceber que o mês de julho (pré-estiagem) apresentou a maior inclinação, seguido por agosto, e janeiro apresenta uma inclinação muito pequena. A inclinação depende da quantidade de folhas verdes nos componentes arbóreo e herbáceo presentes em cada fisionomia. No mês de janeiro a quantidade de folhas verdes nos dois componentes é alta, nos meses de pré-estiagem a quantidade de folhas verdes do herbáceo diminui muito, porém o arbóreo ainda está com folhas verdes. No período de estiagem, a diminuição da quantidade de folhas verdes no herbáceo já não é muito grande (as espécies anuais já não têm mais folhas verdes), porém o arbóreo continua a perder biomassa verde enquanto a estiagem prolonga-se. Assim, a diferença entre as fisionomias, na época de estiagem extrema, diminui (a inclinação diminui) em relação àquela observada nos meses de pré-estiagem.

No mês de julho de 1996 as formas campestres atingiram IVDN inferiores aos valores observados para o mês de maior estiagem (agosto de 95). Esta discrepância em relação ao gradiente mencionado está provavelmente relacionada a uma geada que ocorreu no início do inverno do mesmo ano e causou a morte das folhas de muitos 
indivíduos. As geadas geralmente são de maior intensidade nas partes mais baixas (Camargo, 1971) que, na área de estudo, correspondem às áreas de ocorrência das fisionomias campestres (que apresentaram maior queda no IVDN desta data). A floresta ciliar também apresentou IVDN baixo (aproximadamente igual ao do período de estiagem), ela também localiza-se nas partes mais baixas e sujeitas às geadas. As demais fisionomias com maior participação do componente arbóreo (cerrado senso estrito, cerrado com herbáceo ralo e cerradão) e que ocorrem nas partes mais elevadas, apresentaram IVDN aproximadamente igual ao do mês de julho de 1995. O campo sujo de encosta que ocorre nas partes mais elevadas também apresentou valores de IVDN no mês de julho de 1996 semelhantes aos do mesmo mês do ano de 1995

A floresta estacional semidecidual apresentou os maiores IVDN, mas variações maiores entre o período de estiagem e de maior pluviosidade em relação à fisionomia de cerradão também florestal. Esta diferença na variação sazonal, do IVDN da floresta estacional semidecidual em relação ao gradiente observado para as fisionomias de cerrado, parece estar relacionada com a presença de espécies decíduas, que representam algumas das árvores emergentes desta floresta. É possível que a diminuição na quantidade de folhas verdes destas árvores cause uma redução do IVDN no período de estiagem.

O campo sujo de encosta apresentou baixos IVDN, nos meses de janeiro, junho e julho de 1995, valores inferiores aos das fisionomias campestres (campo úmido, campo de limpo e campo de pteridófitas). Como esta fisionomia tem maior participação do componente arbóreo em relação as campestres, seria esperado IVDN maior para esta fisionomia. É provável que esta queda de IVDN esteja relacionada com o efeito da declividade da escarpa. As imagens Landsat são fortemente afetadas pelo relevo. Este efeito causado pelo relevo já foi apontado por outros autores (Proy et alii, 1989 e Sader et alii, 1989), para as imagens Landsat. Outra possível causa da queda do IVDN é a presença de locais com solo nu exposto decorrente do forte processo erosivo que ocorre nas encostas.

Para avaliar a causa da queda dos valores de IVDN esperados para a fisionomia de campo sujo de encosta, foram extraídas também médias dos valores de 
reflectância na faixa do vermelho, infravermelho próximo e do infravermelho médio. Conforme a figura 5.15., o campo sujo apresenta o valor médio de reflectância mais baixo entre todas as fitofisionomias, em todas as faixas espectrais estudadas e em todas as datas. Este valor relativamente baixo está relacionado com o local de ocorrência, que corresponde a encostas íngremes com as maiores declividades na área da gleba Pé-de-Gigante; caso a queda de IVDN fosse causada pela maior presença de solo nu exposto a reflectância na faixa do vermelho seria mais alta, como acontece com as fisionomias campestres de cerrado.

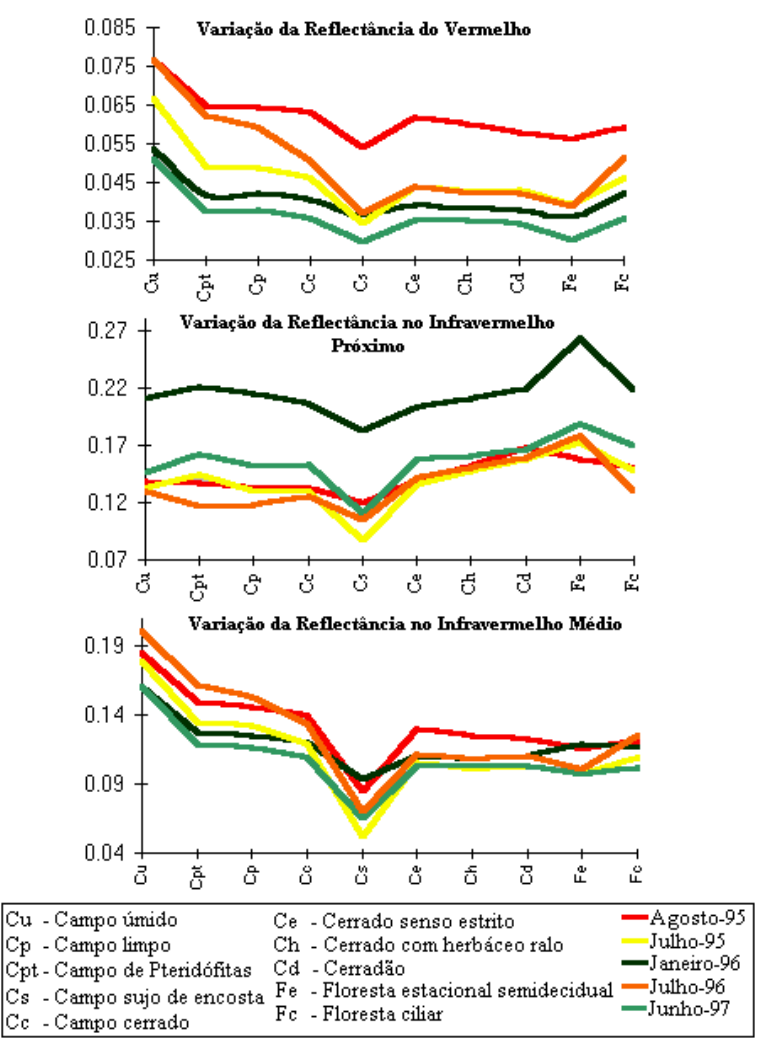

Figura 5.15. - Variação da reflectância média das fitofisionomias obtida por extração dos valores que ocorrem nas áreas de ocorrência.

A figura 5.15. apresenta os valores de reflectância exoatmosférica (ou no nível do satélite) das demais fitofisionomias e permite compreender as características dos alvos em cada faixa espectral, como será descrito a seguir.

Observando na figura 5.15. os valores médios de reflectância das demais fitofisionomias na faixa espectral do vermelho, observa-se um gradiente de reflectância inverso ao gradiente fisionômico apresentado (menor participação do 
componente herbáceo e maior do componente arbóreo). Este gradiente está relacionado com a absorção da energia neste comprimento de onda pela clorofila. Neste caso, as fisionomias campestres apresentam as maiores reflectâncias e as florestais as menores. Assim, a reflectância está inversamente relacionada à atividade fotossintética na folha (maior aproveitamento da luz neste comprimento de onda, menor reflectância). Para este comprimento de onda as fitofisionomias apresentaram diferenças de uma data para outra. As fisionomias campestres apresentaram as maiores variações, comparando-se a época de estiagem e de chuvas. Estas fisionomias atingem os valores de reflectância, próximos aos valores do período de estiagem, na época que precede a estiagem (aproximadamente em julho). O baixos valores de reflectância de floresta estacional semidecidual estão relacionados com o alto aproveitamento da luz. Embora as medidas de luminosidade no nível do solo tenham sido realizadas com sensor com pico de sensibilidade no verde, existe baixa penetração da luz e alto grau de recobrimento por vegetação (a cobretura morta e galhos também contribuem para o valor de recobrimento) que estão relacionados estes valores.

A faixa do infravermelho próximo também apresentou diferenças entre as fisionomias, porém neste caso a variação de reflectância é inversa a observada no vermelho (fig. 5.15.). A reflectância nesta faixa se deve ao retroespalhamento da radiação causado pela estrutura do mesofilo: quanto mais estrutura foliar viva mais reflete infravermelho próximo. Assim, as fisionomias campestres apresentaram os menores valores de reflectância e as florestais, os maiores. Também podemos observar que a variação entre a época de estiagem e de chuvas é maior para as fisionomias campestres. Esta faixa espectral é fortemente influenciada pelo mesofilo das folhas, quanto maior a quantidade de espaços intracelulares, maior a reflectância. Existe uma relação direta entre a quantidade de folhas íntegras e a reflectância. Assim, a vegetação campestre é a que apresenta maior variação nas quantidades de folhas, ao longo do ano. A floresta estacional é a que apresenta maiores valores e a variação nos períodos estiagem e chuvas, também é alta. Estas características estão relacionadas com a complexidade da estrutura vertical desta floresta e com a característica semidecidual da floresta. Nesta faixa espectral a vegetação campestre apresentou 
valores de reflectância no mês de julho de 96, menores que os de agosto de 95 (período tardio de estiagem). Estes valores podem estar relacionados a uma geada que atingiu a região alguns dias antes da aquisição da imagem. A geada causou a morte das folhas (modificação da estrutura celular da folha) de indivíduos do componente herbáceo, e atingiu principalmente as partes mais baixas, onde ocorrem as fisionomias campestres.

A faixa espectral do infravermelho médio está inversamente relacionada com a quantidade de água nas células dos vegetais: quanto mais água no mesófilo menos infravermelho médio reflete (fig. 5.15.). As fisionomias campestres foram as que apresentaram os maiores valores em decorrência da menor quantidade de biomassa verde, e as fisionomias florestais os menores valores em decorrência da maior quantidade de folhas. Neste caso também existe uma variação, entre os períodos de estiagem e de chuvas, maior nas fisionomias campestres do que as fisionomias florestais. Nesta faixa espectral do infravermelho média os desvios em relação a média foram os mais altos (tab. 10.7.). Nestas circunstâncias, pequenas variações entre as diferentes datas podem ser proveniente das técnicas empregadas (principalmente em relação a conversão dos números digitais em reflectância).

O infravermelho próximo influencia o IVDN mais que o vermelho pois quanto mais folhas vivas mais o infravermelho próximo reflete, logo, há mais relação entre o infravermelho próximo e a biomassa verde do que entre o vermelho e a biomassa. As variações entre a reflectância no vermelho nas diferentes fitofisionomias e datas é muito estreita (de 0,03 até 0,077 , ou seja 0,047), enquanto no infravermelho o intervalo de valores é maior e com valores de reflectância mais altos (de 0,088 até 0,264, ou seja 0,176). A relação destes valores é inversa: as fitofisionomias com alta reflectância no infravermelho tem no vermelho a reflectância baixa (fisionomias florestais) e as que possuem reflectância baixa infravermelho tem no vermelho reflectância alta (fisionomias campestres). Assim a participação do vermelho no IVDN torna-se maior nas fisionomias campestres, enquanto nas florestais é muito pequena. No caso da fisionomias estudadas a participação do vermelho aumenta justamente nas fisionomias campestres e que poderiam ter maior influência do solo. Assim, caso o solo esteja participando na reflectância do vermelho (claros e com alto 
brilho como no caso das areias quartzosas), os valores de IVDN encontrados para estas fisionomias estariam ligeiramente subestimados. Esta dedução sugere que existindo participação dos solos, os IVDN das fitofisionomias estariam sendo inferiores ao esperado para a vegetação apenas, desta maneira estas fisionomias seriam mais facilmente separadas das fisionomias florestais (maior IVDN e menor participação do solo). A participação do solo em diferentes densidades de cobertura vegetal foi analisada por Huete et alii (1985), para diferentes tipos de solo, e foi observado que o índice é sensível ao solo em baixas coberturas vegetais. Estudos mais detalhados seriam necessários para comprovar esta hipótese, como por exemplo os que consideram separadamente a participação do solo, como foi sugerido por Huete (1986).

Em todas as faixas espectrais, o campo sujo de encosta apresentou valores baixos em relação aos demais altos (tab. 10.7), como já foi dito anteriormente isto se deve a localização desta fitofisionomia (locais com alta declividade e sujeitos a sombreamento).

O mapa de áreas de ocorrência das fitofisionomias também foi utilizado para extrair os valores mínimo, máximo e médio de outros parâmetros do meio abiótico. Foram extraídos os valores de altitude (tab. 5.1) a partir do MDT (fig. 4.2.a.), e os valores de declividade (tab. 5.1.) a partir do mapa de declividade em graus (fig. 4.2.b.).

Tabela 5.1 - Variação dos valores máximo, mínimo e médio de altitude e declividade, e a área em hectares (projeção horizontal da área superficial) das áreas de ocorrência das fitofisionomias.

\begin{tabular}{|c|c|c|c|}
\hline Categoria & Altitude (metros) & Declividade (graus) & Área (hectares) \\
\hline Campo úmido & $605-631 \quad(629)$ & $0-15 \quad(0.7)$ & 5.2 \\
\hline Campo de pteridófitas & $630-635 \quad(632)$ & $0-7 \quad(2.2)$ & 3.5 \\
\hline Campo Limpo & $606-733 \quad(624)$ & $0-14 \quad(3.5)$ & 15.3 \\
\hline Campo Sujo de Encosta & $660-735 \quad(714)$ & $0-47 \quad(8.9)$ & 10.0 \\
\hline Campo Cerrado & $593-691 \quad(637)$ & $0-20 \quad(4.7)$ & 114.1 \\
\hline Cerrado senso estrito & $590-740 \quad(670)$ & $0-37 \quad(4.2)$ & 599.6 \\
\hline Cerrado com herbáceo ralo & $601-740 \quad(687)$ & $0-38 \quad(4.1)$ & 404.5 \\
\hline Cerradão & $647-730 \quad(680)$ & $0-35 \quad(5.3)$ & 49.1 \\
\hline Floresta Estacional Semidecídua & $622-659 \quad(641)$ & $2-19 \quad(5.9)$ & 16.1 \\
\hline Floresta ciliar & $591-632 \quad(606)$ & $0-17 \quad(2.4)$ & 7.6 \\
\hline Total & $-\ldots$ & $-\ldots$ & 1225.1 \\
\hline
\end{tabular}


$\mathrm{Na}$ área de estudo, a distribuição espacial das fitofisionomias também está relacionada com o relevo; as fisionomias campestres estão ocupando as áreas mais baixas enquanto as fisionomias florestais estão ocupando as partes mais altas. Este padrão de distribuição pode estar relacionado com o padrão de distribuição dos tipos de solo apontado por Massoli (1981). Nas partes mais baixas encontram-se os solos jovens ainda não consolidados. Por isso a vegetação nela instalada não é tão exuberante. A floresta de galeria ocorre nas partes baixas, associada a rede de drenagem. O campo sujo de encosta é uma fisionomia com grande contribuição do componente herbáceo e com poucas árvores. Esta fisionomia ocorre nas regiões altas e com alta declividade; nestas áreas ocorrem solos expostos e inconsolidados (geralmente em processo de erosão). A região apresenta maior área plana ou de relevo suave, as áreas de alto declive estão restritas as encostas do vale.

Para testar a delimitação obtida nas áreas de ocorrência quanto a precisão de localização das fisionomias, foi feita a sobreposição dos pontos de GPS coletados em toda a área de estudo. A cada ponto foi registrada a fisionomia correspondente baseada na descrição das fitofisionomias. Embora as coordenadas dos pontos possua um erro embutido (fig. 3.5.2.), este método pode fornecer um parâmetro para analisar o erro da delimitação das áreas de ocorrência. Os resultados foram apresentados na forma de tabela de coincidência e confusão (tab. 5.2.).

Os resultados indicam que o mapa com as áreas de ocorrência teve boa percentagem de coincidência em relação aos pontos amostrados com o GPS. Embora o valor percentual tenha sido baixo para as fisionomias coincidentes é importante atentar para a técnica utilizada. As áreas amostradas com o GPS correspondem a circulos de 100m de raio, assim fisionomias que tiveram áreas muito pequenas (como campo úmido e floresta ciliar) tiveram a área de teste (do GPS) maior que a da própria fisionomia (ex. campo úmido). Esta opção ocasionou o deslocamento de parte dos pontos de teste para as fisionomias vizinhas. Assim para todas as fisionomias testadas, existe um percentual de pontos da imagem coincidindo com área de ocorrência de cerrado senso estrito e cerrado com herbáceo ralo, fisionomias com maior área e bem distribuídas na área de estudo, e portanto, fazem limites com a maior parte das fitofisionomias. A fisionomia de cerradão, embora não tão pequena na 
totalidade está distribuída em manchas com áreas pequenas, o que acaba resultando no mesmo problema de técnica apontado anteriormente.

Tabela 5.2 - Porcentagem de pontos coincidentes e pontos de confusão, entre os pontos registrados com o GPS e as áreas de ocorrência.

\begin{tabular}{|l|c|c|c|c|c|c|c|c|}
\hline Categoria & $\mathbf{C u}$ & $\mathbf{C s}$ & $\mathbf{C c}$ & $\mathbf{C e}$ & $\mathbf{F c}$ & $\mathbf{C h}$ & $\mathbf{C d}$ & $\mathbf{F e}$ \\
\hline Campo úmido (Cu) & 8,6 & 0 & 0,2 & 0 & 0,7 & 0 & 0 & 0 \\
\hline Campo pteridófitas & 0 & 0 & 6,4 & 0 & 0 & 0 & 0 & 0 \\
\hline Campo limpo (Cp) & 25,0 & 0 & 7,3 & 0 & 19,6 & 0 & 0 & 0 \\
\hline Campo Sujo (Cs) & 0 & 14,3 & 0 & 0,7 & 0 & 2,7 & 0 & 0 \\
\hline Campo Cerrado (Cc) & 53,2 & 0 & 46,9 & 2,4 & 27,5 & 0,1 & 0 & 0 \\
\hline Cerrado sensu estrito (Ce) & 10,9 & 16,3 & 35,8 & 55,1 & 34,8 & 31,4 & 26,6 & 39,6 \\
\hline Cerrado com herbáceo ralo (Ch) & 2,3 & 69,4 & 1,6 & 38,6 & 1,5 & 57,1 & 67,6 & 27,9 \\
\hline Cerradão (Cd) & 0 & 0 & 0 & 2,4 & 0 & 8,7 & 5,8 & 0 \\
\hline Fl. Estacional Semidecídua (Fe) & 0 & 0 & 0 & 0,8 & 0 & 0 & 0 & 32,5 \\
\hline Floresta ciliar (Fc) & 0 & 0 & 1,8 & 0 & 15,9 & 0 & 0 & 0 \\
\hline
\end{tabular}

A participação do solo na radiância registrada pelos sensores orbitais ocorre apenas nas fisionomias com baixa densidade de cobertura vegetal (Huete et alii,1985; Ringrose et alii,1989). Então foi registrada a cor do solo na superfície (tab. 10.6.) em pontos distribuídos sistematicamente na áreas de estudo (fig. 5.16.a). Nas partes mais elevadas, onde a vegetação é desenvolvida, aparecem solos com areia e argilas onde freqüentemente ocorrem solos de cor avermelhada. Nas partes de elevação intermediária ocorrem solos ligeiramente amarelados ou pouco avermelhados (geralmente em áreas com campo cerrado e ou cerrado senso estrito). Nas fisionomias de campo limpo geralmente ocorrem solos lavados, com composição predominante de areias grossas (areias quartzosas) e de cor branca. Nos campos úmidos ocorrem areias quartzosas, porém nas áreas alagadas existe acúmulo de matéria orgânica parcialmente decomposta ocasionando cor do solo preta (fig. 5.16.b). As areias quartzozas brancas e o solos argilosos avermelhados podem alterar a radiância medida nas áreas onde ocorre cobertura vegetal e solo nu. Nas áreas onde ocorrem as fisionomias mais abertas, na gleba Pé-de-gigante, ocorrem solos claros (areias quartzosas) que podem causar um aumento na reflectância na faixa do vermelho. 
Neste caso a tendência seria um pequeno decréscimo no IVDN das fisionomias campestres, e que resultaria em maior de separabilidade em relação as fisionomias florestais. Para quantificar a participação do solo e da necromassa da região no IVDN das fisionomias, seriam necessários estudos mais detalhados como sugerem os trabalhos com modelagem de mistura espectral da vegetação verde com: o solo, sombras, galhos e vegetação morta (Huete, 1986; Smith, 1990; Roberts et alii, 1993; Hall, 1995).

(a)

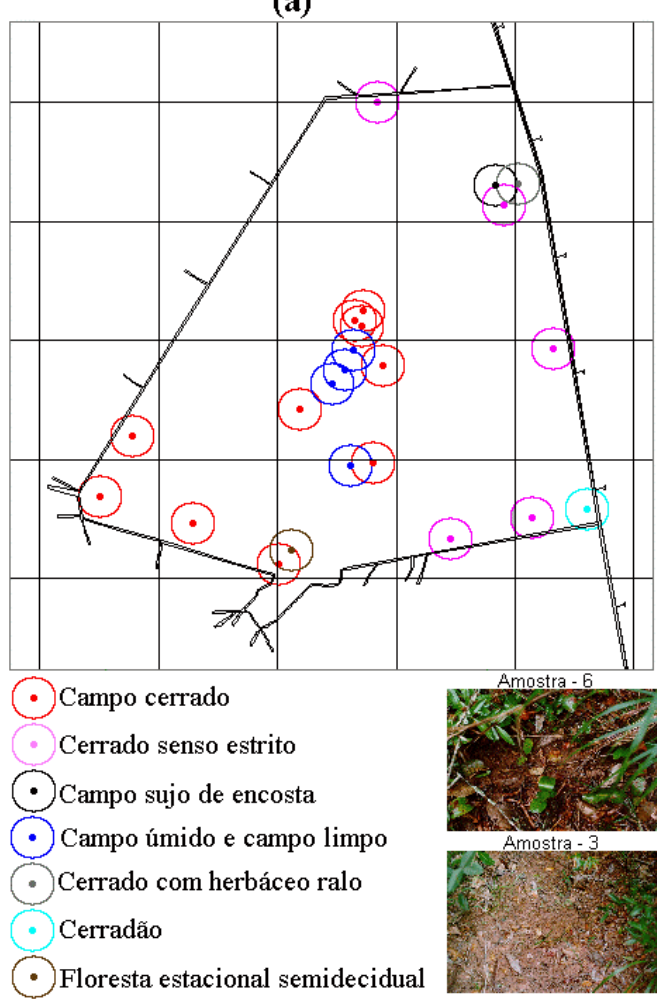

(b)
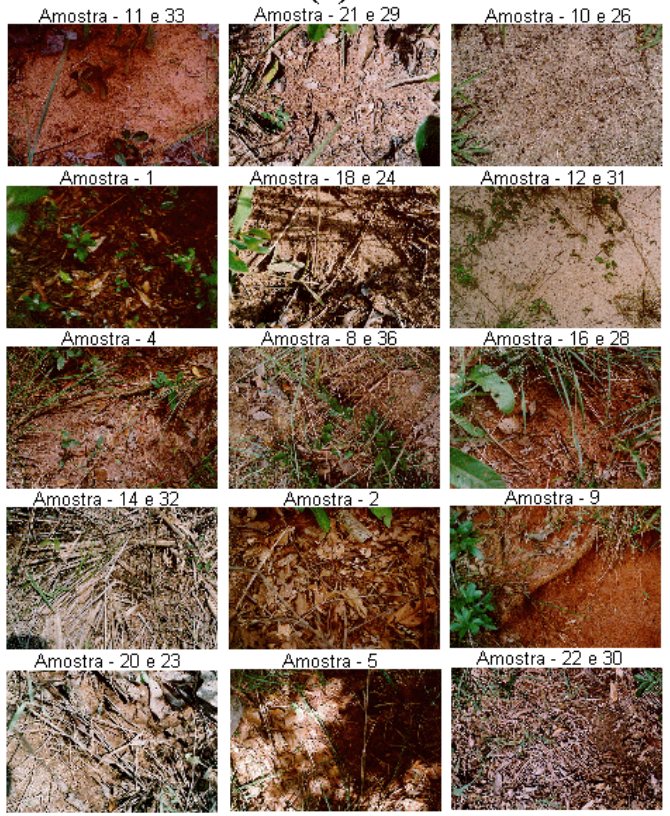

Amostra - 12 e 31
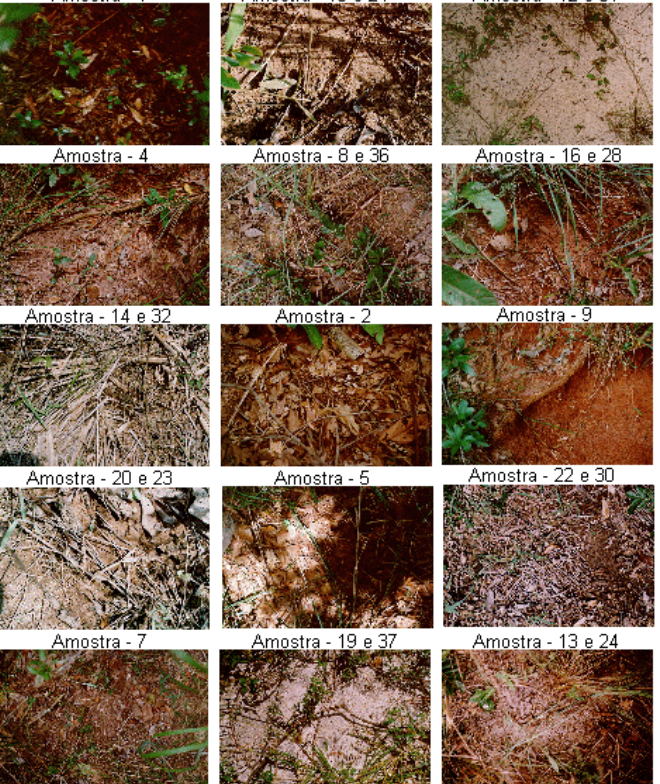
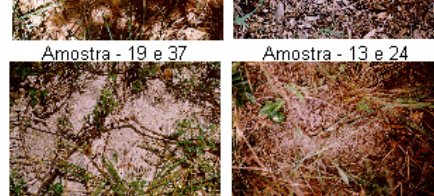

Figura 5.16. - Posição dos pontos selecionados para a coleta de solo superficial na área de estudo (a) e fotografias da superfície do solo na ocasião da coleta da amostra (b).

Nas áreas abertas onde ocorrem o campo úmido e o campo limpo de Melinis ocorrem áreas com solo superficial exposto. No campo cerrado ocorrem algumas áreas um pouco abertas, mas neste caso existe algum acúmulo de serapilheira, então nas partes expostas ocorre mistura de solo exposto e solo coberto com folhas mortas. Nas áreas de cerrado senso estrito, existem poucos locais com solo exposto, e quando ocorrem estão misturados com folhas secas. Nas fisionomias de cerrado com herbáceo ralo, cerradão e floresta estacional semidecidual, a camada de serapilheira é 
continua; é mais espessa na floresta estacional semidecidual. O gradiente fisionômico também está relacionado com o grau de cobertura vegetal.

Para avaliar a possível participação do solo é preciso conhecer o grau de cobertura da vegetação no período de estiagem e de chuvas, pois nas fisionomias mais abertas ocorrem maior participação (Huete et alii, 1985). Dois métodos foram utilizados para estimar a cobertura vegetal: medidas com fotografias verticais do dossel e medida de iluminação relativa.

A cobertura vegetal foi a medida, de forma direta, através da relação entre a quantidade de luz que é interceptada pelo dossel e a que atinge a câmara fotográfica orientada verticalmente no nível do solo (fig. 5.17.a). Este método permite medir a cobertura vegetal constituída de folhas e galhos, verdes e secos, que interceptam a luz.. As fisionomias campestres apresentam a menor cobertura vegetal, enquanto as florestais apresentam a maior cobertura. Para todas as fisionomias amostradas ocorre diminuição da cobertura vegetal no período de estiagem, possivelmente relacionada com aumento da abscisão e senescência foliar das fisionomias.

Os valores obtidos através do método de medida da iluminação relativa (medida indireta da cobertura) apresentaram o mesmo padrão observado com as fotografias verticais, ou seja, menor luminosidade nas fisionomias florestais e maior nas fisionomias campestres (fig. 5.17.b), e um ligeiro aumento no período de estiagem. Comparando-se as fitofisionomias nas épocas de maior quantidade de chuvas e o período de estiagem, fica claro que existe maior cobertura vegetal no período de chuvas. A variação entre a cobertura vegetal no período de estiagem e de chuvas é maior nas fisionomias campestres e menor nas fisionomias florestais. 


\section{Cobertura Vegetal (Fotografias Verticais)}

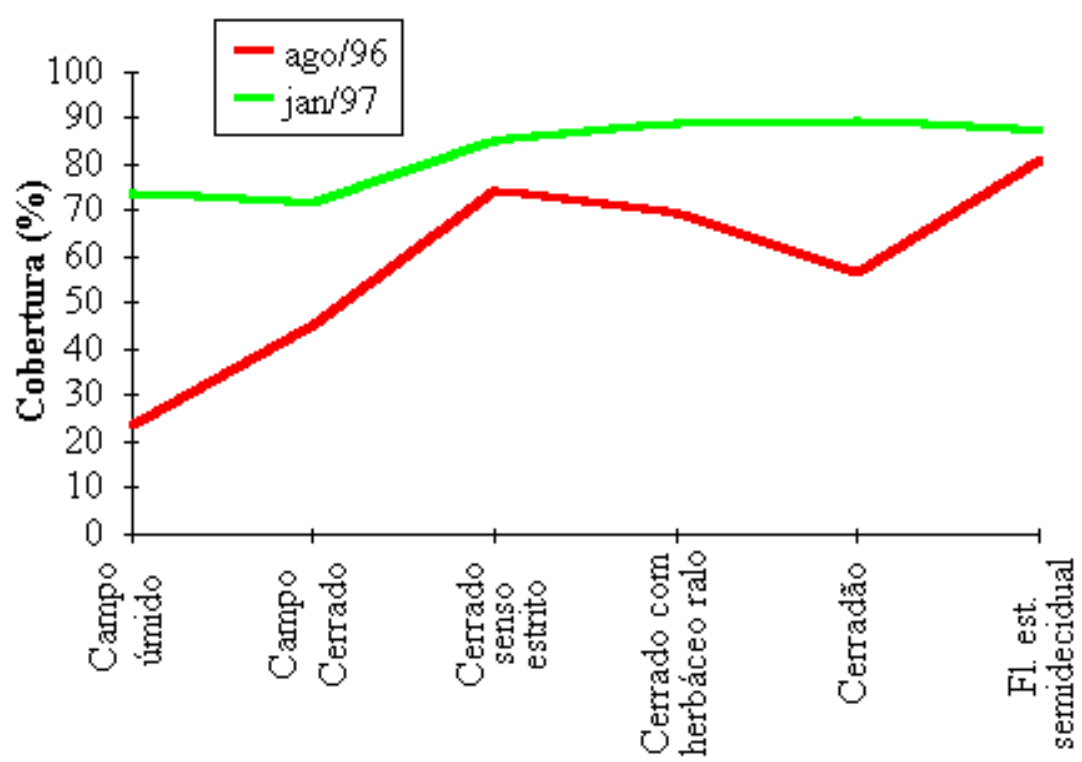

(a)

Fitofisionomias

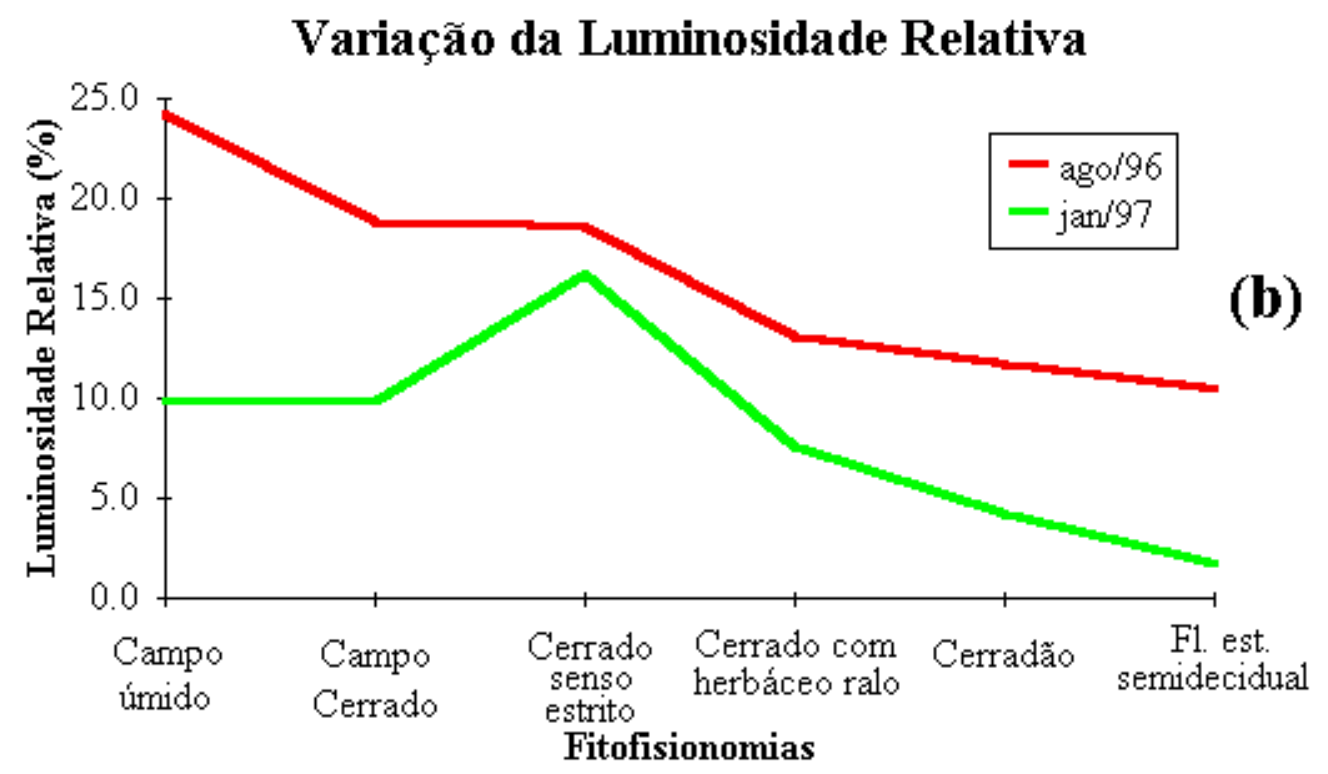

Figura 5.17. - a.) Variação da cobertura vegetal nas fisionomias medida através das fotografias verticais da vegetação. b.) Variação da luminosidade relativa (medida da iluminação, com luxímetro, acima do dossel e no nível do solo) em algumas das fitofisionomias observadas na área de estudo.

Para avaliar o efeito da topografia no IVDN de cada data, foram realizados alguns procedimentos utilizando a superfície do MDT (gerado a partir das curvas de nível, figura 4.1.a.). A partir desta superfície classificou-se a declividade e a orientação das quatro principais vertentes (Norte, Sul, Leste e Oeste), bem como o 
plano. No que tange à declividade, foram separadas duas classes de 0 a 7 graus (chamado aqui de plano) e maiores que 7 graus (chamado de não plano). Somou-se a imagem booleanas de maiores de 7 graus de declividade com as classes de vertentes Norte, Sul, Leste e Oeste. Sobrepondo-se o mapa de áreas de ocorrência fitofisionômica, foram escolhidos três morfotipos com representantes nas cinco situações de iluminação e extraídos os IVDN nas 5 datas. As fisionomias com maior representatividade nas cinco condições de iluminação (quatro vertentes principais e o plano) são o campo cerrado, o cerrado senso estrito e o cerrado com herbáceo ralo.
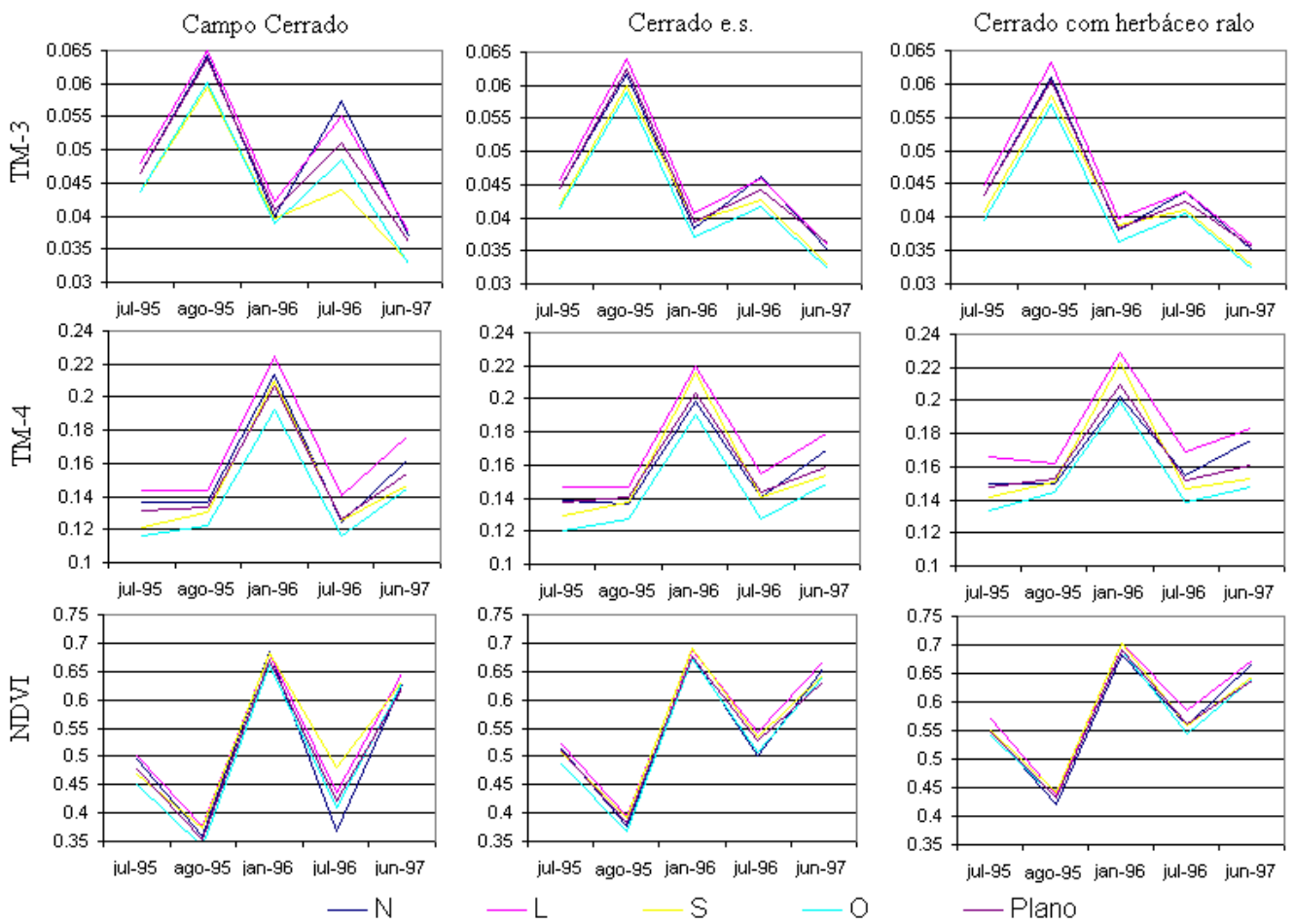

Figura 5.18. - Médias extraídas de cada vertente em relação a média extraída para os terrenos planos (0 a 7 graus), obtidas para as área de ocorrência: do campo cerrado, cerrado senso estrito e cerrado com herbáceo ralo. As média foram extraídas nas diferentes datas de aquisição das imagens: IVDN, faixa do vermelho e faixa do infravermelho próximo.

A orientação das vertentes em relação a posição do Sol no instante da aquisição das imagens, nas cinco datas, influencia a resposta espectral da vegetação (fig. 5.18.). As cinco imagens foram adquiridas em horários semelhantes (ângulo do Norte para Leste igual $42^{\circ}$ graus, ângulo horário do sol em relação ao Norte), porém com diferentes ângulos de elevação solar (julho de $95=27^{\circ}$, agosto de $95=34^{\circ}$, janeiro de $96=45^{\circ}$, julho de $96=30^{\circ}$, junho de $97=32^{\circ}$ ), o que resultou em 
diferente iluminação do relevo para cada data. A diferença de iluminação decorrente do ângulo de elevação solar foi corrigida na conversão dos números digitais em grandeza física (Mesquita Jr. \& Bitencourt, 1997), porém a posição do sol - dada pelo ângulo de elevação solar e pelo ângulo zenital em relação a superfície do terreno vão determinar diferentes tipos de sombreamento do relevo.

A partir da posição do Sol na abóbada celeste e do MDT foram geradas imagens de iluminação relativa com o programa IDRISI, para as imagens dos meses de julho e janeiro, respectivamente: menor e maior ângulo do elevação solar (fig. 5.19.). A vertente leste (4.2.c) é a que está voltada para o Sol no momento da aquisição das imagens, e a vertente oeste (4.2.c.) é a que esta voltada a favor do Sol, ou seja, fica sombreada ou na penumbra.

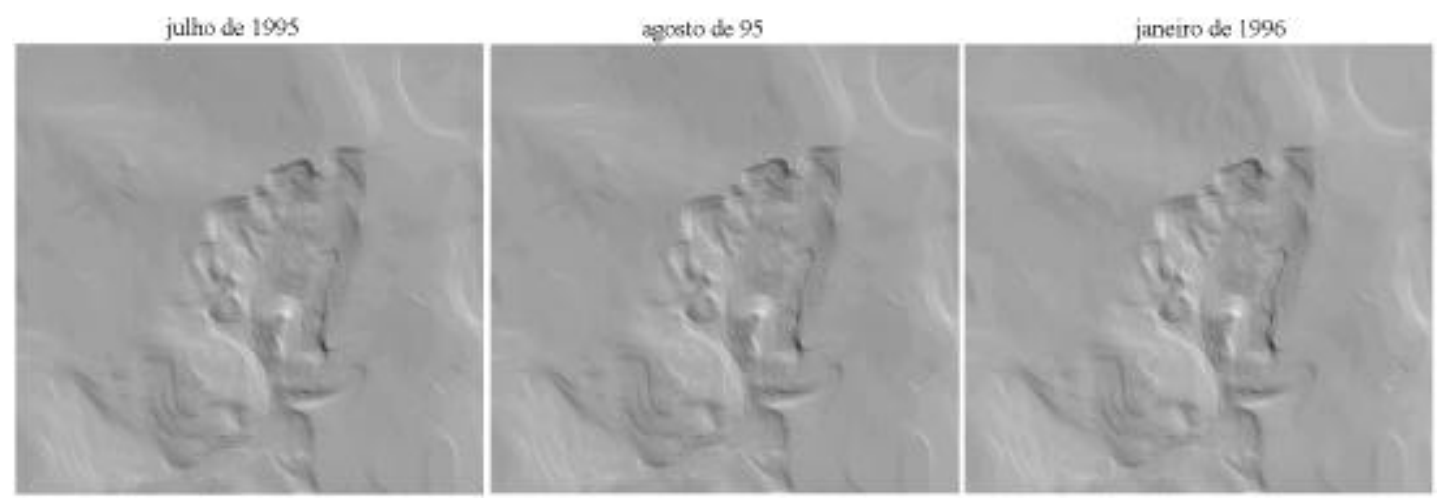

Figura 5.19. - Imagens de iluminação relativa para o mês de julho (ângulo de inclinação solar $=27^{\circ} \mathrm{e}$ $42^{\circ}$ de azimute), agosto (ângulo de inclinação solar $=34^{\circ}$, e $42^{\circ}$ de azimute) e janeiro (ângulo de elevação solar $=45^{\circ}$ e $44^{\circ}$ de azimute).

A figura 5.19. mostra os IVDN médios e os valores de reflectância na faixa do vermelho e infravermelho, obtidos para três fisionomias de cerrado que ocorrem em áreas planas e nas quatro vertentes (Norte, Sul, Leste e Oeste). A reflectância na faixa espectral do infravermelho é mais afetada pelo efeito da topografia que a faixa espectral do vermelho. Os valores nas datas no mês de julho foram os mais afetados pela topografia e representam o mês com o menor ângulo de elevação solar. A fisionomia de campo cerrado parece ser a mais afetada pelo ângulo de elevação. A vertente leste e a vertente oeste são as que mais afetam os valores de reflectância na duas faixas espectrais. A vertente Leste apresenta valores sempre maiores do que do plano, e a vertente Oeste valores menores. De maneira geral, as vertentes Norte e Sul 
não afetam muito os IVDN. A vertente norte apresenta valores ligeiramente maiores e a vertente sul ligeiramente menores. A variação entre as quatro principais vertentes está relacionada à posição do sol, no horário de aquisição das imagens o Sol encontrase do lado leste (azimute de 42 graus), e ligeiramente deslocado para o Norte nos meses de inverno do hemisfério Sul. Os IVDN das três fisionomias apresentam as mesmas variações apontadas para as faixas espectrais da vermelho e infravermelho, porém de forma reduzida. O IVDN é uma razão (diferença normalizada), assim os efeitos das vertentes em relação ao plano são atenuados.

Os resultados obtidos estão de acordo com a literatura. Sader et alii (1989), estudando florestas tropicais, observaram diferenças entre o IVDN das faces das quatro principais vertentes, porém não mencionaram a posição relativa do sol na ocasião da aquisição da imagem. Proy et alii (1989) quantificaram e modelaram os efeitos causados pela topografia nas imagens Landsat TM; a vertente com a face voltada para o sol apresenta maior reflectância e a vertente oposta sombreada tem menor reflectância. $\mathrm{O}$ efeito da sombra apontado aqui para as fisionomias de cerrado na diferentes datas depende também da rugosidade do dossel (Hall, 1995). Para conhecer a contribuição da sombra na análise espectral das fisionomias de cerrado seria importante analisar também a sombra causada pela rugosidade do dossel.

\section{Conclusões}

a.) O método empregado neste trabalho associou as informações espectrais, na forma de IVDN, das imagens do satélite Landsat TM (no período de chuvas, préestiagem e estiagem), com dados obtidos em campo e cartográficos. Este método permitiu identificar os tipos fisionômicos de cerrado, reconhecer a distribuição espacial e delimitar as áreas de ocorrência das fisionomias de cerrado e das fitofisionomias associadas.

b.) A análise espectral com o IVDN em cinco datas foi relacionada com o clima regional. As imagens IVDN nas datas de máximas chuvas, pré-estiagem e estiagem 
mostraram, nessa ordem, que o índice diminui com a diminuição na quantidade de folhas verdes. Esta variação está relacionada com o estado fenológico das fisionomias, assim a perda de folhas verdes por abscisão e senescência implica em diminuição do IVDN. Cada fisionomia apresentou um padrão anual de variação do IVDN, decorrente da quantidade de participação do componente herbáceo e arbóreo. No cerrado senso lato a variação do IVDN, no período de chuvas em relação ao de estiagem, é maior nas fisionomias campestres e menor nas florestais. $\mathrm{Na}$ análise espectral da vegetação é necessário considerar também as condições do tempo na ocasião do registro da imagem. A ocorrência de uma geada pode causar a morte de folhas e resultar na diminuição do IVDN das fisionomias de cerrado.

c.) Com o resultados obtidos neste estudo, foi possível estabelecer o melhor período para análise espectral da vegetação com imagens IVDN. Do ponto de vista espectral, o melhor período para separar as fisionomias de cerrado é o período de pré-estiagem, pois apresenta maior contraste entre as fisionomias campestres e florestais. À medida em que a estiagem prolonga-se, este contraste diminui. $\mathrm{Na}$ estiagem aumenta a confusão entre as fisionomias que possuem maior participação do componente herbáceo e arbustivo. O período de alta pluviosidade mostrou maior confusão entre as fisionomias de cerrado, porém apresentou contraste entre a floresta estacional semidecidual e o cerradão.

d.) Os valores médios de IVDN obtidos para as fisionomias não diferem muito dos obtidos por outros autores que utilizaram o cerrado como objeto de estudo. Os trabalhos que utilizaram sensores Landsat TM ou MSS apresentaram valores semelhantes aos obtidos neste trabalho. Aqueles utilizando o sensor AVHRR apresentaram IVDN geralmente mais baixos.

e.) O tamanho amostral da área das fitofisionomias associadas às de cerrado não é muito grande, o que gera incerteza com relação a possíveis generalizações dos valores encontrados para estas fitofisionomias, em outras áreas. Porém a separação das áreas de ocorrência das fitofisionomias associadas se faz necessária, pois os 
IVDN podem coincidir com as fisionomias de cerrado. A melhor forma utilizada para separar estas fitofisionomias foi utilizar também informações do meio abiótico através do SIG, informações que restringem fitofisionomia à ocupar somente a área com as condições determinadas.

f.) No estudo multitemporal das imagens de satélite, principalmente nas latitudes mais altas das zonas tropicais, é muito importante considerar a variação da iluminação. As posições relativas do sol na abóbada celeste no momento da aquisição da imagem variam durante o ano. Esta variação causa mudanças na qualidade da radiação incidente e no tipo de sombreamento do alvo. A conversão dos números digitais em grandeza física é uma forma de minimizar este efeito. A análise da radiação refletida nas diferentes vertentes também pode servir para identificar o grau de interferência do relevo e iluminação.

g.) A topografia associada com as condições de iluminação influenciam os valores de IVDN encontrados para uma fitofisionomia. A vertente com a face voltada para o Sol apresentou valores de IVDN ligeiramente mais altos e a vertente voltada para oeste valores ligeiramente mais baixos. Analisando os valores de reflectância individualmente nas faixas do vermelho e do infravermelho o efeito da topografia é maior, ou seja, o IVDN atenua estes efeitos causados pelo relevo.

\section{Considerações}

Alguns dados de posicionamentos poderiam ser mais precisos com um tempo maior de registro ou com a aplicação de novos métodos de registro dos ponto com o GPS. A tecnologia dos equipamentos desenvolve-se muito rápido, assim a tomada dos dados atualmente poderia melhorar muito a qualidade da informação. A atualização de técnica com aumento no número de ponto aumentaria a precisão dos posicionamentos e diminuiria a incerteza das delimitações das áreas de ocorrência. 
Embora o posicionamento dos pontos de checagem possuam um erro, estes pontos foram utilizados como parâmetro de avaliação do resultado obtido na delimitação das áreas de ocorrência de cada fisionomia.

As médias obtidas para cada fisionomia representaram de forma discreta a variação de IVDN encontrada na área delimitada como área de ocorrência. Estes valores foram então apresentados em linha contínua para o conjunto de fisionomias numa determinada época do ano. $\mathrm{O}$ objetivo foi expressar a tendência de variação entre as fisionomias, mas não foram consideradas as variações que ocorrem dentro da área de ocorrência.

A classificação multitemporal, utilizando mais uma data para análise da vegetação, não pode ser realizada com um intervalo muito grande de tempo. A vegetação está sujeita diversos tipos de variações que não sejam variações sazonais. As fisionomias de cerrado estão, segundo o conceito de Coutinho (1978), em tensão ecológica entre floresta e campo. Desta forma, variações nas condições ambientais ao longo de um período, podem favorecer o desenvolvimento de um componente em relação ao outro.

Dentre as informações geradas neste estudo, a análise das diferentes datas pode ser útil para os profissionais que trabalham com imagens de satélite, para análise da vegetação. A seleção da melhor data e aquisição da imagem, que venha a fornecer mais informações sobre o objeto de interesse, ou seja, a melhor época para separar as fisionomias. Embora seja um estudo de caso, os resultados estão indicando como ocorrem as variações nas fisionomias de cerrado.

As informações obtidas e a metodologia empregada forneceram informações sobre o cerrado numa escala de abordagem de ecologia da paisagem. Os resultados deste trabalho podem servir para futuras análises do cerrado. O estudo mostrou que a metodologia empregada pode ser utilizada em conjunto com outros métodos de análise de vegetação, como por exemplo, a fitossociologia. O sistema de informação geográfica foi muito útil, e pode servir a quem estuda a distribuição espacial da vegetação.

De maneira secundária foram produzidos materiais que puderam ser úteis a outros profissionais que trabalharam na área de estudo. Foi realizado um trabalho de 
mestrado por Marco Antonio Batalha sobre a composição florística, fenologia e fitossociologia do cerrado na área de estudo (Batalha, 1997). O trabalho citado utilizou parte dos dados apresentados aqui para seleção das áreas amostrais e localização dos tipos fisionômicos. O material produzido durante o andamento do trabalho, também serviu como subsídio para o plano de manejo da unidade de conservação. Foram produzidos mapas derivados dos mapas temáticos produzidos neste trabalho. Alguns trabalhos de pesquisa estão sendo, e serão, realizados na mesma área de estudo e os dados aqui apresentados também servirão a estas pesquisas em andamento, principalmente no que se refere à localização espacial das fisionomias. Neste sentido, o trabalho apresentou bons resultados também, por ter sido testado por vários pesquisadores.

\section{Recomendações às pesquisas subseqüentes}

É possível que as áreas de ocorrência das fisionomias de cerrado não sejam absolutamente homogêneas. Neste trabalho foi aplicado um método para relacionar as informações de campo às informações espectrais das imagens de satélite. A heterogeneidade das manchas das áreas de ocorrência de uma fisionomia pode ser estudada utilizando amostragens sistemáticas para obtenção de dados de campo em diferentes escalas. A paisagem poderia ser estudada para dar a conhecer a relação entre as manchas de cada fisionomia, como ocorrem os gradientes de vegetação e a transição entre fisionomias muito distintas.

A análise temporal poderia ser mais detalhada caso estivessem disponíveis imagens do período subsequente a estiagem. O IVDN das fisionomias no período pósestiagem, quando se iniciam as chuvas, deve aumentar pois a vegetação inicia a rebrota das folhas (aumento da biomassa verde). É possível que o aumento de folhas verdes ocorra igualmente nos dois componentes arbóreo e herbáceo nas fisionomias. A análise espectral das fisionomias nesta época poderia fornecer informações.

Uma contribuição importante para futuros estudos das fisionomias de cerrado por meio de análise espectral seria quantificar a possível interferência do solo e outros 
contribuintes na mistura espectral de cada ponto, de 30 por 30 metros, na imagem. $\mathrm{O}$ gradiente fisionômico está relacionado com a diminuição de densidade de vegetação e de cobertura vegetal, isto sugere que as fisionomias campestres tenham maior participação do solo na mistura espectral. As fisionomias de cerrado também apresentam diferenças quanto à rugosidade do dossel, o que pode ocasionar diferente contribuição da sombra da vegetação na mistura espectral.

Os resultados encontrados podem ainda servir como critério para sistema de decisões para cerrados na área do estado de São Paulo, pois as características observadas nesta amostra de cerrado senso lato é semelhante fisionomicamente às demais que ocorrem no estado. O método poderia ser aplicado em sistemas de decisão para discriminação das fisionomias de cerrado em áreas maiores do estado.

O sistema geográfico de informações e as imagens de satélite, da forma como foram utilizados neste trabalho, têm um grande potencial para análise da vegetação. As informações geradas sobre a dinâmica dos processos de mudança de estado fenológico através da análise espectral e análise da distribuição geográfica da vegetação, podem ser experimentados em outras vegetações. Para o cerrado em particular, o método foi muito bem sucedido e as informações geradas poderão ser utilizadas em outros estudos sobre o cerrado.

\section{Referências bibliograficas}

ANDERSON, G.L.; HANSON, J.D.; HAAS, R.H.; 1993 - Evaluating Landsat Thematic Mapper Derived Vegetation Indices for Estimating Above-Ground Biomass on Semiarid Rangelands. Remote Sensing of Environment, 45:165-175. Elsevier Science Publishing Co. Inc., New York.

AOKI, H. \& SANTOS, J.R.; 1979 - Fatores ambientais dos cerrados e imagens orbitais.

Boletim Técnico do Instituto Florestal, 31:1-69, set. Instituto Florestal, São Paulo.

Azevedo, A.; 1972 - Brasil a Terra e o Homem - As bases físicas. vol. 1. Editora Nacional, São Paulo. 
BALl,G.L.; 1994 - Ecosystem Modeling with GIS. Environmental Management Vol.18, No.3, pp 345-349. Springer-Verlag, New York.

Batalha, M.A.; 1997 - Análise da Vegetação da ARIE Cerrado Pé-de-Gigante (Santa Rita do Passa Quatro, SP). Dissertação apresentada ao Instituto de Biociências da Universidade de São Paulo, como parte dos requisitos exigidos para a obtenção do titulo de mestre em Ecologia.

Bertoni, A.; Negreiros, O.C.; Cesar, S.F.; Noof, M.S.; Pfeifer, R.M.; Serio, F.C.; Domingues, E.N.; SILva, C.E.F.; Durigam, G.; Moraes, J.L.; Andrade, W.J.; Silva, D.A.; Barbaosa, A.F.; Ceneviva, W.; Mattos, I.F.A.; 1986 - Plano conceitual de manejo do Parque estadual de Vassununga. Boletim Técnico do Instituto Florestal. Vol. 40-A, parte 1, edição especial. Instituto Florestal, São Paulo.

Bitencourt, M.D. \& Mesquita JR., H.N.; (em impressão) - Brazilian Savannas Physiognomies Analysis with NDVI. Memorias do VIII Simpósio Latino Americano de Percepcion Remota. Mérida, Venezuela, 2 al 7 de noviembre de 1997.

Bitencourt, M.D.; Mesquita Jr.; Mantovani, W.; Batalha, M.A.; Pivello, V.R.; 1997 - Identificação das fisionomias de Cerrado com Imagem Índice de Vegetação Diferença Normalizada. In:. LEITE, L.L. \& SAITO, C.H. (editores). Contribuição ao Conhecimento Ecológico do Cerrado. 1ed. Cap. 7 (Metodologia Aplicada à Ecologia), pp. 316-320. Universidade Federal de Brasília, Brasilia.

Bitencourt-Pereira, M.D.; 1986 - Correlação de fitomassa foliar de Campo Cerrado com dados espectrais obtidos pelo sistema MSS-LANDSAT e por radiometria de campo. São José dos Campos, 90 p. INPE-3747-TDI203

BLITZKOW , D.; 1995 - NAVSTAR/GPS - Um desafio tornado realidade. Anais do III simpósio brasileiro de geoprocessamento, 12 a 14 de julho de 1995, Escola Politécnica da Universidade de São Paulo, São Paulo .

BocZKo, R. (org.); 1995 - Anuário Astronômico 1996. Instituto Astronômico e Geofísico da Universidade de São Paulo, São Paulo. 
Borgonovi, M. \& Chiarini, J.V.; 1965 - Cobertura vegetal do estado de São Paulo - Levantamento por fotointerpretação das áreas cobertas com cerrado, cerradão e campo, em 1962. Bragantia 24(14): 159-172. Instituto Agronômico do Estado de São Paulo.

Borgonovi, M.; Chiarini, J.V.; Amaral, A.Z.; Coelho, A.G.S.; Oliveira, D.A.; 1967 - Levantamento por fotointerpretação das áreas cobertas com floresta natural e reflorestamento. Bragantia 26(6): 93-102. Instituto Agronômico do Estado de São Paulo.

CÂMara,I.G.; 1993 - Conservação dos Cerrados. In: Monteiro, S. \& KAZ, L. (coord.); 1993 - Cerrado: Vastos espaços. Livroarte Editora, Rio de Janeiro - RJ.

Camargo, A.P.; 1971 - Clima do Cerrado. In: Ferri, M.G. (ed.) Simpósio sobre o cerrado. Editora Edgar Blucher Ltda., São Paulo.

CARvalHO, L.M.T.; 1997 - Dinâmica de clareiras em uma floresta de nuvem na serra de Ibitiboca - MG. Dissertação apresentada à Universidade Federal de Lavras, para obtemção do título de mestre.

CARvalho, V.C.; 1986 - Síntese e análise dos 25 anos (1961-1986) de atividades do INPE/SRE voltadas para a área de vegetação/floresta. Instituto de Pesquisas Espaciais, São José dos Campos - SP.

CASTRO, A.A.J.F.; 1987 - Florística e fitossociologia de um cerrado marginal brasileiro, Parque Estadual de Vassununga, Santa Rita do Passa Quatro

- SP. Tese de Mestrado apresentada ao Instituto de Biologia da Universidade de Campinas, Campinas - SP.

Chaves JR., P.S.; 1989 - Radiometric Calibration of Landsat Thematic Mapper Multispectral Images. Photogrammetric Engineering and Remote Sensing, 55(9): 1285-1294. American Society for Photogrammetry and Remote Sensing.

Choudhury, B.J.; 1987 - Relationships Between Vegetation Indices, Radiation Absortion, and Net Photosynthesis Evaluated by Sensitivity Analysis. Remote Sensing of Environment. Vol. 22, pp. 209-233. Elsevier Science Publishing Co. Inc., New York. 
Colwell, R.N. (ed.), 1983 - Manual of Remote Sensing - Theory, Instruments and Techniques. Vol. 1 e 2, American Society of Photometry, The Sheridan Press, Virginia.

Coutinho, L.M.; 1978 - O conceito de cerrado. Revista Brasileira de Botânica 1(1): 17-23. Sociedade Botânica do Brasil, São Paulo.

CrostA, A.P.; 1993 - Processamento digital de imagens de sensoriamento remoto. ed. revisada, 170p. IG/UNICAMP, Campinas.

Curran, P.J.; Dungan, J.L.; Gholz, H.L.; 1992 - Seasonal LAI in Slash Pine Estimated with Landsat TM. Remote Sensing of Environment, 39:3-13. Elsevier Science Publishing Co. Inc., New York.

Cyr , L.; Bonn, F.; Pesant, A.; 1995 - Vegetation indices derived from remote sensing for a estimation of soil protection agaist water erosion. Ecological Modelling 79:277-285.

DA SILVA,W.S.; FORNASARI-FILHO, N.; 1992 - Unidades de conservação ambiental e áreas correlatas no estado de São Paulo. 2 ed., Instituto de Pesquisas Tecnológicas, São Paulo - SP.

De Mello-Filho, L.E.; 1993 - Uma Visão de Cerrado. In: Monteiro, S. \& KaZ, L. (coord.); 1993 - Cerrado: Vastos espaços. Livroarte Editora, Rio de Janeiro - RJ.

Durigan, G.; SARAiva, I.R.; Gurgel Garrido, L.M.A.; GARrido, M.A.O.; PeChe FILHO, A.; 1987 - Fitossociologia e Evolução da Densidade da Vegetação de Cerrado, Assis, SP. Boletim Técnico do Instituto Florestal, 41(1): 59-78. Instituto Florestal, São Paulo.

EASTMAN, J. R. ; 1995 - Idrisi for windows user manual, version 1.0. Clark University, Worcester.

EITEn G. ; 1972 - The Cerrado Vegetation of Brazil. The Botanical Review, 38 (2): 201-341. The New York Botanical Garden, New York.

EllenberG, H.; Mueller-Dombois, D.A.; 1965/66 - Tentative physiognomicecological classification of plant formations of the earth. Ber. Geobot. 37:2155. Inst. ETH, Zurich. 
EMBRAPA - Empresa Brasileira de Pesquisa Agropecuária e Secretaria de Agricultura e Abastecimento do Estado de São Paulo, 1982 - Levantamento Pedológico Semidetalhado do Estado de São Paulo (escala 1:100.000), Quadrícula de Descalvado, Folha SF.23-V-C-IV.

FERRI, M.G.; 1971 - Histórico dos trabalhos botânicos sobre o cerrado. In: FERRI, M.G.; 1971 - Simpósio sobre o cerrado. Ed. Edgar Blucher Ltda., São Paulo.

FrAnÇA, H.; 1994 - Um estudo fenológico com imagens AVHRR/NOAA nos Cerrados do Parque Nacional de Emas, GO. Disertação de Mestrado em Sensoriamento Remoto, INPE, São Jose dos Campos, SP.

FunG, I.Y. \& TUCKER, C.J.; 1986 - Remote Sensing of the terrestrial Biosphere. Proceedings of a Workshop Climate-Vegetation Interactions at NASA, 27-29 January 1986. Office for Interdisciplinary Earth Studies, University Corporation for Atmospheric Research.

Gamon, J.A.; Field, C.B.; Goulden, M.L.; Griffin, K.L.; Hartley, A.E.; Joel, G.; Peñuelas, J.; Valentini, R.; 1995 - Relationships between NDVI, canopy structure, and photosynthesis in three Californian vegetation types. Ecological Applications, 5(1):28-41. Ecological Society of America.

Gamon, J.A.; Penuelas, J. ; Field, C.B.; 1992 - A Narrow-Waveband Spectral Index That Tracks Diurnal Changes in Photosynthetic Efficiency. Remote Sensing of Environment. Vol. 41, pp. 35-44. Elsevier Science Publishing Co. Inc., New York.

Garrison, W.L., AleXander, R.; BAILey, W.; DACEy, M.F.; MARble, D.F.; 1965 Data systems requirements for geographic research. in Scientific Experiments for Manned Orbital Flight. Proceedings of the American Astronautical Society's Third Goddard Memorial Symposium.

GateS, D.M.; KeEgan, H.J.; Scheter, J.C.; WeIDneR, V.R.; 1965 - Spectral Properties of Plants. Applied Optics, 4(1): 11-20. Optical Society of America, New York. 
GAUSSMAN, H.W.; 1984 - Evaluation of factors causing reflectance differences between sun and shade leaves. Remote Sensing of Environment 15: 177181. Elsevier Science Publishing Co. Inc., New York.

Goodland, R. \& Ferri, M.G.; 1979 - Ecologia do Cerrado. Ed. da Universidade de São Paulo \& Ed. Itatiaia Ltda, São Paulo.

Goward, S.N. \& Huemmrich, K.F.; 1992 - Vegetation Canopy PAR Absorbency and the Normalized Difference Index: An Assessment Using the SAIL Model. Remote Sensing of Environment. Vol. 39, pp. 119-140. Elsevier Science Publishing Co. Inc., New York.

Hall, F.G.; Shimabukuro, Y.E.; Huemmrich, K.F.; 1995 - Remote Sensing of Forest Biophysical Structure Using Mixture Decomposition and Geometric Reflectance Models. Ecological Applications, 5(4): 993-1013.

HILL, J.; 1991 - A quantitative approach to remote sensing: sensor calibration and comparison. In: BewARD, A.S. \& VALENZUELA, C.R. (eds.); 1991 - Remote sensing and geographical Information systems for resource management in developing countries. Brussels and Luxenburg, Netherlands.

Huete, A.R.; 1986 - Separation of Soil-Plant Spectral Mixtures by Factor Analysis. Remote Sensing of Environment. 17: 37-53. Elsevier Science Publishing Co. Inc., New York.

Huete, A.R.; Jackson, R.D.; Post, D.F.; 1985 - Spectral Response of a Plant Canopy with Different Soil Backgrounds. Remote Sensing of Environment. 17: 37-53. Elsevier Science Publishing Co. Inc., New York.

IBDF, 1982 - Plano do Sistema de Unidades de Conservação do Brasil. II etapa, IBDF, Brasília.

IBGE - Instituto Brasileiro de Geografia e Estatística, 1971 - Carta do Brasil (escala 1:50.000), Luís Antônio, Folha SF-23-V-C-IV-2. Instituto Brasileiro de Geografia e Estatística, Rio de Janeiro.

IBGE - Instituto Brasileiro de Geografia e Estatística; 1991 - Manual técnico da vegetação brasileira. Fundação Instituto Brasileiro de Geografia e Estatística, Departamento de Recursos Naturais e Estudos Ambientais - Rio de Janeiro. 
IG - Instituto Geológico do Estado de São Paulo, 1986 - Formações Geológicas de Superfície (escala 1:50.000), Folha Geológica de Luís Antônio, Folha SF.23-V-C-IV-2. Instituto Geológico do Estado de São Paulo, São Paulo.

IGC - Instituto Geográfico e Cartográfico do Estado de São Paulo, 1990a - Plano Cartográfico do Estado de São Paulo (escala 1:10.000), Folha Córrego Água Santa, SF-23-V-C-IV-2-SO-B. Instituto Geográfico e Cartográfico do Estado de São Paulo, São Paulo.

IGC - Instituto Geográfico e Cartográfico do Estado de São Paulo, 1990b - Plano Cartográfico do Estado de São Paulo (escala 1:10.000), Folha Ribeirão Vassununga, SF-23-V-C-IV-2-NO-F. Instituto Geográfico e Cartográfico do Estado de São Paulo, São Paulo.

IQBAL, M. ; 1983 - An introduction to solar radiation. Academic Press, Toronto.

KoEPPEN, W.; 1948 - Climatologia - con un estudio de los climas de la Tierra. Fondo de cultura econômica, Mexico

Kronka, F.J.N.; Matsukuma, C.K.; Nalon, M.A.; Del-Cali,I.H.; Rossi, M.; Mattos, I.F.A.; Shin-IKe, M.S.; Pontinhas, A.A.S.; 1993 - Inventário Florestal do Estado de São Paulo. Instituto Florestal, Secretaria do Meio Ambiente, São Paulo.

KronKa, F.J.N.; Nalon, M.A.; Matsukuma, C.K.; PavÃo, M.; Guilaumon, J.R.; Cavalli, A.C.; Gianotti, E.; Ywane, M.S.S.; Lima, L.M.P.R.; Montes, J. DEL-CALI,I.H., HAACK, P.G.; em impressão - Áreas de domínio de cerrado no estado de São Paulo. Instituto Florestal, São Paulo.

LeES, B.G.; RitMAn, K.; 1991 - Decision-tree and rule induction approach tointegration of remotely sensed data and GIS data in mapping vegetation disturbed or hilly environments. Environmental Management, vol.15, No. 6, pp 823-831. Springer-Verlag, New York.

Leitão-Filho, H.F \& AZEvedo, D.B.; 1989 - Critérios gerais para a implantaçãode um Parque Ecológico. Editora da Unicamp, Campinas - SP.

LIETH, H. (ED.); 1974 - Phenology and Seasonality Modeling. Ecological Studies, Vol. 8. Springer-Verlag New York Inc., New York. 
LiLlesand, T.M. \& KIEFER, R.W.; 1995 - Remote Sensing and Image Interpretation. 3 ed., John Wiley \& Sons, Inc, New York.

LIOU, KUO-NAN; 1980 - An Introduction to atmospheric radiation. Academic Press, New York.

LOH,D.K. \& RYKIEL JR, E.J.; 1992 - Systems with data base management and geographic information systems. Environmental Management Vol.16, No.2, pp. 167-177.

Mantovani, W.; Leitão-Filho, H.F.; Martins, F.R.; 1985 - Chave baseada em caracteres vegetativos para a identificação de espécies lenhosas do cerrado da reserva biológica de Mogi Guaçu, Estado de São Paulo. Hoehnea 12:35-56.

MARKHAM, B. L. \& BARKER, J. L. ; 1986 - Landsat MSS and TM Post-calibration dinamic ranges, exoatmospheric reflectânces and At-satellite temperatures. EOSAT Landsat Technical Notes, number 1.

Massoli, M. ; 1981 - Geologia do Município de Santa Rita do Passa Quatro,SP. Revista do Instituto Geológico, 2(2):35-45, jun./dez. Instituto Geológico, São Paulo.

Mesquita JR, H.N. \& BitencourT, M.D. ; 1997 - Conversão dos Números Digitais em Grandezas Físicas no Estudo Multitemporal da Vegetação de Cerrado. Livro de Resumos do II Simpósio de Usuários do IDRISI, 18 a 20 de agosto 1997, pp. 25-29. EMBRAPA/CNPTIA, UNICAMP/CEPAGRI, Campinas.

Milano, M.S.; 1993 - Unidades de Conservação: Conceitos básicos eprincípios gerais de planejamento, manejo e administração In: ROTHEN-DE-S, R.F.; Wandembruck, A.; 1993 - Manejo de áreas Naturais Protegidas (Apost.). Universidade Livre do Meio Ambiente, Curitiba - PR.

Millington A.C.; Styles, P.J.; CRitchley, R.W.; 1992 - Mapping forest and savannas in sub-Saharan Africa from advanced very high resolution radiometer (AVHRR) imagery. In: Furley, P.A.; Proctor, J.; RAtTer, J.A. (eds.); 1992 - Nature and Dynamics of Forest-Savanna Bounderies. Chapman \& Hall, London. 
Moore, D.M.; LeES, B.G.; DAveY, S.M.; 1991 - A New Method for predicting Vegetation Distributions using Decision Tree Analysis in Geographic Information System. Environmental Management, vol.15, No. 1, pp 59-71. Springer-Verlag New York Inc., New York.

Morain, S.A.; 1974 - Phenology and Remote Sensing. In: LIETH, H. (ed.); 1974 Phenology and Seasonally Modeling. Ecological Studies, Vol. 8. SpringerVerlag New York Inc., New York.

Mueller-Dombois, D.; 1984 - Classification and Mapping of plant Communities: Review with emphasis on tropical vegetation. In: WoODWELL, GM. (ed.); 1984 - The role of terrestrial vegetation in the global carbon cycle: measurement by remote sensing. Jonh Wiley \& Sons Ltd.

MunSEll COLOR; 1975 - Munsell Soil Color Charts. Macbeth a Division of Kollmorgen Corporation, Baltimore, Maryland.

NougueirA-Neto, P.; 1991 - Savanas neotropicais uma proposta de taxonomia para os cerrados e outros geobiomas-climáticos. Editora Tecnapis, São Paulo - SP.

Observatório Nacional, 1996 - Efemérides Astronômicas. CNPq - Observatório Nacional, Rio de Janeiro.

PINTER JR, P.J.; 1993 - Solar Angle Independence in the Relationship between Absorbed PAR and Remotely Sensed Data for Alfalfa. Remote Sensing Environment, 46: 19-25. Elsevier Science Publishing Co. Inc, New York.

Polcyn, F.C.; Spansail, N.A.; MalidA, W.A.; 1969 - How Multispectral Sensing Can Help the Ecologist. In: JoHnson, P.L. (ed.); 1969 - Remote Sensing in Ecology. University of Georgia Press.

Proy, C.; TAnnRÉ, D.; Deschamps, P.Y.; 1989 - Evaluation of Topographic Effects in Remotely Sensed Data. Remote Sensing Environment, 30: 21-32. Elsevier Science Publishing Co. Inc, New York.

QI, J.; Huete, A.R.; Moran, M.S.; Chehbouni, A.; Jackson, R.D.; 1993 Interpretation of Vegetation Indices Derived from Multi-temporal SPOT Images. Remote Sensing Environment, 44: 89-101. Elsevier Science Publishing Co. Inc, New York. 
RAUKIER, C.; 1934 - The life forma of plants and statistical plant geography. New York, Oxford University Press.

RAwitscher, F; Ferri, M.G.; RACHID, M.; 1943 - Profundidade dos solos e vegetação em campos cerrado do Brasil meridional. Anais da academia brasileira de ciências, tomo XV, No. 4. Academia Brasileira de Ciências, Rio de Janeiro.

Ricotta, C.; Avena, G.C.; FerRI, F.; 1996 - Analysis of human impact on a forested landscape of central Italy with a simplified NDVI texture descriptor. International Journal of Remote Sensing, 17 (14): 2869-2874. Taylor \& Francis Ltd.

Ringrose S.; Mathson, W.; Mogotsi, B.; TemPest, F.; 1989 - The Darkening Effect in Drought Affected Savanna Woodland Environments Relative to Soil Reflectance in Landsat and SPOT Wavebands. Remote Sensing Environment, 30:1-19. Elsevier Science Publishing Co. Inc, New York.

RIZZINI, C.T.; 1971 - A flora do cerrado. In: FERRI, M.G.; 1971 - Simpósio sobre o cerrado. Ed. Edgar Blucher Ltda, pp 105-154.

RoBerTs, D.A.; SMITH, M.O.; ADAMS, J.B.; 1993 - Green Vegetation, Nonphotosynthetic Vegetation, and Soil in AVIRIS Data. Remote Sensing Environment, 44: 255-269. Elsevier Science Publishing Co. Inc, New York.

RoBinOve, C.J. ; 1982 - Computation with physical values from Landsat digital data.

Photogrammetric Engineering and Remote Sensing, 781-784. American Society for Photogrammetry and Remote Sensing..

RoSA, R.; 1992 - Introdução ao Sensoriamento Remoto. 2 ed., Ed. EDEFU, Uberlândia - SP.

SADER, S.A.; WAIDE, R.B.; LAWRENCE, W.T.; JOYCE A.T.; 1989 - Tropical Forest Biomass and Sucessional Age Class Relationships to a Vegetation Index Derived from Landsat TM Data. Remote Sensing Environment, 28: 143156. Elsevier Science Publishing Co. Inc, New York.

SANTOS, J.R. \& AOKI, H.; 1980 - Técnicas de sensoriamento remoto a nível orbital como subsídio ao estudo da vegetação de cerrado. Boletim Técnico do Instituto Florestal, 31:1-69, set. Instituto Florestal, São Paulo. 
SANTOS, J.R.; 1988 - Biomassa aérea da vegetação de cerrado: estimativa e correlação com dados do sensor "Thematic Mapper" do satélite LANDSAT. Tese de Doutorado - Universidade Federal do Paraná, Curitiba 208p.

Saraiva I.R.; Trindade, M.L.B.; HernandeZ-Filho, P.; 1987 - Avaliação Visual das Imagens do Sensor "Thematic Mapper" na Classificação da Vegetação. Boletim Técnico do Instituto Florestal, 41(2):323-336. Instituto Florestal, São Paulo.

SARMIENTO, G.; 1992 - A conceptual model relating environmental factors and vegetation formations in the lowlands of tropical South America. In: FURLEY, P.A.; Proctor, J.; RATter, J.A. (eds.); 1992 - Nature and Dynamics of Forest-Savanna Boundaries. Chapman \& Hall, London.

SENUS, W.J. \& HILL, R. W.; 1981 - GPS Applications to map, charting and geodesy. In: JANICZEK, P.M.; 1984 - Global Positioning System - Navigation. Vol. 2 , Institute of Navigation, Washington, D.C.

Serra Filho, R.; Cavalli, A.C., Guillaumon, J.R., Chiarini, J.V.; Nogueira, F.P.; IVAncko, C.M.A.M.; BARbieri, J.L.; Donzeli, P.L.; CoElho, A.G.S.; BitTEnCOURT, I.; 1974 - Levantamento da cobertura vegetal natural e do reflorestamento no estado de São Paulo. Boletim Técnico do Instituto Florestal, Vol. 11. Instituto Florestal, São Paulo.

Shimabukuro, Y.E.; CARVAlho, V.C.; RudorfF, B.F.T.; 1997 - NOAA-AVHRR data processing for the mapping of vegetation cover. International Journal of Remote Sensing, 18 (3): 671-677. Taylor \& Francis Ltd.

SMA - Secretaria do Meio Ambiente; 1997 - Cerrado: bases para a conservação e uso sustentável das áreas de cerrado do estado de São Paulo. Secretaria do Meio Ambiente, São Paulo.

SMith, M.O.; Ustin, S.L.; AdAMS, J.B.; GILlesPIE, A.R.; 1990 - Vegetation in deserts: I. Regional Measure of Abundance from Multispectral Images. Remote Sensing Environment, 31: 1-26. Elsevier Science Publishing Co. Inc, New York. 
Stavinschi, M.; Vass, G.; Popescu, H.; Vaduvesco, O.; 1994 - Anuarul Astronomic 1995. Editora Academiei Române.

STEINER, F.; 1991 - Landscape planning: A method applied to a growth management example. Environmental Management Vol.15, No.4, pp 519529.

Tucker C.J.; Townshed J.R.G.; GoFf, T.E.; 1985 - African Land-Cover Classification Using Satellite Data. Science, Vol.227, No. 4685.

TUCKER, J.C.; 1979 - Red and Photographic Infrared Linear Combinations for Monitoring Vegetation. Remote Sensing Environment, 8: 127-150. Elsevier Science Publishing Co. Inc, New York.

TUCKER, J.C.; 1980 - Remote Sensing of Leaf Water Content in the Near Infrared. Remote Sensing Environment, 10: 23-32. Elsevier Science Publishing Co. Inc, New York.

WALteR, H.; 1955 - Die Klimadiagrammeals Mittel zur Beurteilung der Kliverhältnisse für ökologische, vegetionskundliche und landwirtscaftliche Zwecke. Ber. Dtsch. Bot. Ges. 68:331-344

Walter, H.; Breckle, Siegmar-W.; 1985 - Ecological Systems of the Geobiosphere. vol.1. Springer-Verlag, Berlin.

WELCH, R. \& REMILLARD, M.; 1992 - Integrtion of GPS, remote sensing and GIS techniques for costal resource management. Photogrammetric Engineering \& Remote Sensing, Vol. 58, No.11, Nov., pp 1571-1578.

Welch, R.; REMILlaRD, M.; DOREN, R.F.; 1995 - GIS Database development for south Florida's National Parks and Preserves. Photogrammetric Engineering \& Remote Sensing, Vol. 61, No.11, Nov., pp 1371-1381.

Wiengand, C. L.; Richardson, A.J.; EsCOBAR, D.E.; GERBERMANn A.H.; 1991 Vegetation Indices in Crop Assessments. Remote Sensing Environment, 35: 105-119. Elsevier Science Publishing Co. Inc, New York.

XIANG,W.; 1993 - Application of a GIS-based stream buffer generation model to environment policy evaluation. Environmental Management Vol.15, No.4, pp 519-529. 


\section{Anexos}

Tabela 10.1. - Valores médios de IVDN, biomassa epígea, teor de umidade e número de amostras utilizadas (entre parênteses) para comparação, obtidos em (Bitencourt-Pereira, 1986).

\begin{tabular}{|c|c|c|c|}
\hline Amostras (Média) & J-MSS6/7 & $\operatorname{Biomassa}\left(\mathrm{g} / \mathrm{m}^{2}\right)$ & Teor $(\%)$ \\
\hline Média CPAC - DF (1) & 0.328 & 554 & 65.9 \\
\hline Média Posse-GO (4) & 0.310 & 377 & 24.9 \\
\hline Média Planaltina - DF (11) & 0.469 & 597 & 52.2 \\
\hline
\end{tabular}

Tabela 10.2. - Valores de IVDN, Biomassa e Teor de Umidade Médios e o número de amostras utilizadas (entre parênteses) para a média na comparação (Santos, 1988).

\begin{tabular}{|c|c|c|c|c|}
\hline Amostras (Média) & Data & IVDN-TM4/3 & Biomassa $\left(\mathrm{g} / \mathrm{m}^{2}\right)$ & Teor $(\%)$ \\
\hline Média CPAC I (8) & $\begin{array}{l}17 / 06 / 86 \\
45\end{array}$ & 0.551 & 542 & \\
\hline Média CPAC II (8) & $\begin{array}{l}04 / 08 / 86 \\
42\end{array}$ & 0.511 & 372 & \\
\hline Média UnB I (5) & $\begin{array}{l}17 / 06 / 86 \\
45\end{array}$ & 0.584 & 703 & \\
\hline Média UnB II (5) & $\begin{array}{l}04 / 08 / 86 \\
42\end{array}$ & 0.529 & 488 & \\
\hline Média IBGE I (6) & $\begin{array}{l}17 / 06 / 86 \\
47\end{array}$ & 0.619 & 716 & \\
\hline Média IBGE II (6) & $\begin{array}{l}04 / 08 / 86 \\
43\end{array}$ & 0.550 & 505 & \\
\hline
\end{tabular}

Tabela 10.3. - Valores médios de IVDN obtidos por França (1994) e o número de áreas amostrais utilizadas (entre parênteses) na comparação.

\begin{tabular}{ll}
\hline Amostras (Média) & IVDN \\
\hline Emas- Abril-92 (1) & 0.25 \\
Emas-Maio-93 (1) & 0.25 \\
Emas- Junho-92/93 (7) & 0.21 \\
Emas-Julho-92/93 (11) & 0.16 \\
Emas-Agosto-93 (2) & 0.13 \\
Emas-Setembro-92 (2) & 0.14 \\
Emas-Outubro-93 (2) & 0.22 \\
\hline
\end{tabular}


Tabela 10.4. - Descrição das fitofisionomias observadas em campo, nas transeções de Leste para Oeste e de Norte para Sul.

\begin{tabular}{|c|c|c|}
\hline & Perfil Norte - Sul (21/01/97) & Perfil Norte - Sul (12/08/96) \\
\hline Ponto - 01 (GPS) & $\begin{array}{l}\text { Campo cerrado: } \\
\text { (Anadenanthera falcata) } 4 \text { a } 5 \text { metros } \\
\text { de altura muito esparsas, herbáceo } \\
\text { com Capim-Flexa (Tristachya } \\
\text { leiostachya) e Capim-Gordura } \\
\text { (Melinis minutiflora) e outras } \\
\text { gramíneas de menor ocorrência. } \\
\text { Arbustos de } 0,5 \text { a 1m (Senna rugosa, } \\
\text { Bauhinia rufa, Attalea geraensis e } \\
\text { outras). }\end{array}$ & $\begin{array}{l}\text { Campo cerrado: Muito Campim- } \\
\text { gordura (Melinis minutiflora) seco, } \\
\text { angicos (Anadenanthera falcata) } \\
\text { esparsos de } 5 \text { a } 7 \text { metros e algumas } \\
\text { arvoretas de } 1,5 \text { a } 2,5 \text { metros de altura, } \\
\text { arvores maiores muito esparsas. }\end{array}$ \\
\hline Ponto - 02 & $\begin{array}{l}\text { Campo cerrado: Idem anterior } \\
\text { arbustivo de } 1 \mathrm{~m} \text { a } 2 \mathrm{~m}, \\
\text { Anadenanthera falcata } \\
\text { esparsa. Herbáceo com (Capim-Flexa } \\
\text { (Tristachya leiostachya), Capim- } \\
\text { Gordura (Melinis minutiflora) e } \\
\begin{array}{l}\text { Ichnanthus sericeus), Arbustivo com } \\
\text { Miconia albicans, Bauhinia rufa e } \\
\text { Qualea parviflora. }\end{array}\end{array}$ & $\begin{array}{l}\text { Campo cerrado: diminuição do capim } \\
\text { gordura e aumento das arvoretas de } 1,5 \\
\text { a } 2,5 \text { metros de altura, arvores grandes } \\
\text { muito esparsas, estrato herbáceo muito } \\
\text { seco. }\end{array}$ \\
\hline Ponto - 03 & $\begin{array}{l}\text { Cerrado senso estrito: Fim do campo } \\
\text { cerrado início do cerrado senso estrito } \\
\text { estrato herbáceo com Capim-Flexa } \\
\text { (Tristachya leiostachya) e Capim- } \\
\text { flexinha e arbustivo com Pouteria } \\
\text { torta, Xilopia aromatica, Cariocar } \\
\text { brasiliensis, Roupala montana e } \\
\text { Bauhinia rufa). }\end{array}$ & $\begin{array}{l}\text { Cerrado senso estrito: Ainda existem } \\
\text { gramíneas em tufos descontínuos } \\
\text { aumento do número de arbustos e de } \\
\text { arvoretas arvores não tão esparsas. A } \\
\text { vegetação dos estratos herbáceo e } \\
\text { arbustivo estão secas. }\end{array}$ \\
\hline Ponto - 04 & $\begin{array}{l}\text { Cerrado senso estrito: Nos primeiros } \\
\text { metros Dossel de 5m de altura com } \\
\text { Xilopia aromatica, Pouteria torta, } \\
\text { Tabebuia ochracea, e estrato } \\
\text { herbáceo com Rhyncospora exaltata } \\
\text { e Vochysia cinamommea nos metros } \\
\text { finais presença de emergentes como } \\
\text { Pterodon pubescens de } 7 \mathrm{~m} \text { de altura } \\
\text { diminuição da Rhyncospora exaltata } \\
\text { e aumento do Ananas ananassoides } \\
\text { aparecimento de muita Banisteriopsis } \\
\text { pubipetala. }\end{array}$ & $\begin{array}{l}\text { Cerrado senso estrito: Neste ponto a } \\
\text { vegetação tem folhas verdes, } \\
\text { anteriormente estava completamente } \\
\text { seca. Aumento na densidade de árvores } \\
\text { e ausência de gramíneas, maior } \\
\text { sombreamento aparente do solo. Grande } \\
\text { quantidade de Malpighiaceas volventes } \\
\text { como Banisteriopsis pubipetala. }\end{array}$ \\
\hline Ponto - 05 & $\begin{array}{l}\text { Cerrado com herbáceo ralo: a partir } \\
\text { dos } 10 \mathrm{~m} \text { iniciais cerado com herbáceo } \\
\text { ralo, estrato herbáceo com } \\
\text { Rhyncospora exaltata mas muito } \\
\text { esparsas, aumento na quantidade de } \\
\text { Plântulas, Dossel } \\
\text { aproximadamente } 6 \text { metros de altura } \\
\text { com emergentes de até } 10 \mathrm{~m} \text { como } \\
\text { Anadenanthera falcata, Pterodon } \\
\text { pubescens pubecens e Xilopia } \\
\text { aromatica, presença de sub-bosque } \\
\text { com Strychnos bicolor, Erythroxylum }\end{array}$ & $\begin{array}{l}\text { Cerrado com herbáceo ralo: } \\
\text { Formação de aspecto florestal com } \\
\text { vegetação com folhas verdes, início da } \\
\text { formação de um dossel superior } \\
\text { contínuo } \\
\text { Malpighiaceas, aumento no número de } \\
\text { plântulas. Aspecto de bosque, é fica } \\
\text { fácil caminhar no interior, aumento na } \\
\text { densidade de árvores. }\end{array}$ \\
\hline
\end{tabular}




\begin{tabular}{|c|c|c|}
\hline & $\begin{array}{l}\text { cuneifolium e Miconia albicans, neste } \\
\text { trecho ainda ocorrem Banisteriopsis } \\
\text { pubipetala e Banisteriopsis stellaris. }\end{array}$ & \\
\hline Ponto - 06 (GPS) & $\begin{array}{l}\text { Cerrado com herbáceo ralo: Dossel } \\
\text { de } 5 \text { a } 6 \mathrm{~m} \text { com Copaifera langsdorfii, } \\
\text { Virola sebifera, Xilopia aromatica, } \\
\text { Qualea grandiflora e Myrcia lingua, } \\
\text { emergente Pterodon pubescens, muita } \\
\text { plântulas na sinusia inferior, Syagrus } \\
\text { loefgrenii e ausência de Rhyncospora } \\
\text { exaltata. }\end{array}$ & $\begin{array}{l}\text { Cerrado com herbáceo ralo: Alta } \\
\text { densidade de árvores formando um } \\
\text { dossel continuo variável em altura de } 6 \\
\text { a } 8 \text { metros. Ocorrência de plântulas, } \\
\text { algumas Rhyncospora exaltata e } \\
\text { Ananas ananassoides no estrato } \\
\text { inferior. A vegetação esta com folhas } \\
\text { verdes. }\end{array}$ \\
\hline Ponto - 07 & $\begin{array}{l}\text { Cerrado com herbáceo ralo: Dossel } \\
\text { de } 5 \text { a } 6 \mathrm{~m} \text { com emergente Pterodon } \\
\text { pubescens de até } 10 \mathrm{~m} \text {. Virola } \\
\text { sebifera, Hymenaea stigonocarpa, } \\
\text { Xilopia aromatica, Vochysia } \\
\text { tucanorum e Myrcia lingua, muita } \\
\text { plântulas na sinusia inferior e poucas } \\
\text { Rhyncospora exaltata }\end{array}$ & $\begin{array}{l}\text { Cerrado com herbáceo ralo: algumas } \\
\text { emergentes com } 6 \text { a } 8 \text { metros de } \\
\text { altura, dossel com } 3 \text { a } 4 \text { metros de } \\
\text { altura (muitas arvoretas). No estrato } \\
\text { inferior, muitas plântulas e algumas } \\
\text { Rhyncospora exaltata. Muitos arbustos } \\
\text { escandentes como por exemplo o } \\
\text { Strychnos bicolor. }\end{array}$ \\
\hline Ponto - 08 & 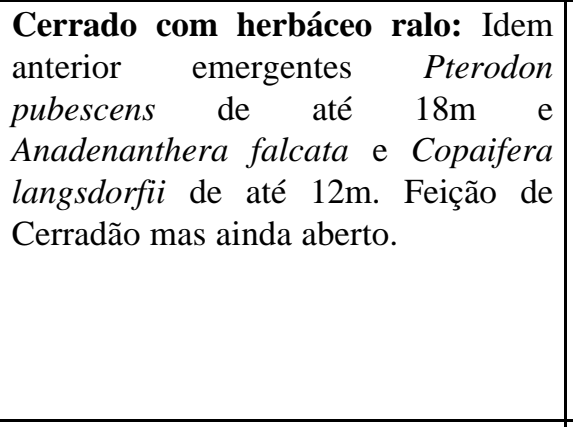 & $\begin{array}{l}\text { Cerrado com herbáceo ralo: Algumas } \\
\text { emergentes como o Pterodon pubescens } \\
\text { e a Anadenanthera falcata, atingindo } \\
\text { de } 10 \text { a } 12 \text { metros de altura. O dossel } \\
\text { continuo tem de } 4 \text { a } 6 \text { metros de altura. } \\
\text { Ausência de gramíneas, no estrato } \\
\text { inferior, muitos arbustos escandentes } \\
\text { como o Strychnos bicolor, porém em } \\
\text { menor quantidade em relação ao ponto } \\
\text { anterior. A vegetação tem folhas verdes. }\end{array}$ \\
\hline Ponto - 09 & $\begin{array}{l}\text { Cerrado com herbáceo ralo: A } \\
\text { partir dos 10m primeiros metros } \\
\text { cerradão (face Sudeste) dossel com } 8 \mathrm{a} \\
10 \text { metros e emergentes com 15 } \\
\text { metros. Muita Virola sebifera, e } \\
\text { presença de Qualea grandiflora, } \\
\text { Xilopia aromatica, Aspidosperma } \\
\text { tomentosum, Anadenanthera falcata e } \\
\text { Roupala montana.. A camada de } \\
\text { serapilheira é espessa, plantas jovens } \\
\text { retas, finas e alongadas. Presença de } \\
\text { alguns indivíduos de Banisteriopsis } \\
\text { stellaris. }\end{array}$ & $\begin{array}{l}\text { Cerradão: Dossel contínuo com } \\
\text { aproximadamente } 10 \text { metros de altura } \\
\text { com poucas emergentes de } 12 \text { metros de } \\
\text { altura. No estrato inferior apenas } \\
\text { plântulas com aspecto estiolado, } \\
\text { ausência de gramíneas (face da vertente } \\
\text { voltada para leste). O solo é bem } \\
\text { sombreado a vegetação está com folhas } \\
\text { verdes. }\end{array}$ \\
\hline Ponto - 10 & $\begin{array}{l}\text { Cerrado senso estrito: os primeiros } \\
15 \text { metros cerradão depois mudança } \\
\text { abrupta para cerrado senso estrito, } \\
\text { herbáceo com Rhyncospora exaltata e } \\
\text { Pteridóftas (Gleichenia flexuosa) } \\
\text { Dossel muito denso com muitos } \\
\text { individuos de Xilopia aromatica de } \\
\text { até } 2 \mathrm{~m} \text { de altura, Miconia albicans e } \\
\text { Miconia rubiginosa, Kielmeyera } \\
\text { rubriflora. Emergentes com até } 5 \mathrm{~m} \text { de } \\
\text { altura próximas entre si, com }\end{array}$ & $\begin{array}{l}\text { Cerrado senso estrito: Arvores com } 6 \\
\text { a } 8 \text { metros de altura relativamente } \\
\text { esparsas e dossel continuo e muito } \\
\text { denso com } 2,5 \text { a } 3 \text { metros de altura. } \\
\text { Muitas arvoretas com folhas verdes } \\
\text { como Xilopia aromatica e Virola } \\
\text { sebifera, e Malpighiaceas volventes. }\end{array}$ \\
\hline
\end{tabular}




\begin{tabular}{|c|c|c|}
\hline & $\begin{array}{l}\text { Stryphnodendron adstringens, } \\
\text { Anadenanthera falcata, Tocoyena } \\
\text { formosa. }\end{array}$ & \\
\hline Ponto - 11 (GPS) & $\begin{array}{l}\text { Campo cerrado: Até os primeiros } \\
35 \mathrm{~m} \text { Cerrado s. s. após Campo } \\
\text { Cerrado. Estrato herbáceo com } \\
\text { Capim-flexa (Tristachya leiostachya) } \\
\text { e Capim-flexinha, Ichnanthus } \\
\text { sericeus, e poucas Rhyncospora } \\
\text { exaltata esparsas. Muito arbustos de } \\
\text { até } 1 \mathrm{~m} \text { de altura, como Byrsonima } \\
\text { intermedia, Miconia rubiginosa. } \\
\text { Emergentes muito esparsas de } 3 \text { a } 4 \\
\text { metros de altura como Vochysia } \\
\text { tucanorum, Cariocar brasiliensis, } \\
\text { Anadenanthera falcata e Pouteria } \\
\text { torta. }\end{array}$ & $\begin{array}{l}\text { Cerrado senso estrito: A partir deste } \\
\text { ponto as folhas estão todas secas. } \\
\text { Dossel continuo com } 2 \mathrm{~m} \text { e misto com } \\
\text { arvore dispersas. Presença de arvoretas } \\
\text { e arbustos. No estrato inferior } \\
\text { gramíneas e arbustos. }\end{array}$ \\
\hline Ponto - 12 & $\begin{array}{l}\text { Cerrado senso estrito: Dossel com } \\
\text { aproximadamente } 2 \text { metros de altura, } \\
\text { mas bastante denso, estrato herbáceo } \\
\text { com Capim-flexa (Tristachya } \\
\text { leiostachya) e aumento do Capim- } \\
\text { gordura (Melinis minutiflora), } \\
\text { arbustivo com muitos indivíduos } \\
\text { mortos em pé com rebrotas na base do } \\
\text { caule, como Miconia rubiginosa, } \\
\text { Tabebuia aurea e Vochysia } \\
\text { tucanorum, emergentes muito } \\
\text { esparsas com Anadenanthera falcata } \\
\text { de } 7 \mathrm{~m} \text { de altura. }\end{array}$ & $\begin{array}{l}\text { Cerrado senso estrito: A vegetação } \\
\text { esta seca, dossel com predomínio de } \\
\text { arvoretas de } 2,5 \text { a } 3 \text { metros de altura, } \\
\text { com arvores dispersas. Aumento na } \\
\text { quantidade de gramíneas no estrato } \\
\text { inferior. Esta tem tendência a } \\
\text { fisionomia de Campo Cerrado. }\end{array}$ \\
\hline Ponto - 13 (GPS) & $\begin{array}{l}\text { Floresta ciliar: Fim do Cerrado senso } \\
\text { estrito e início da Floresta ciliar. } \\
\text { Dossel com aspecto semelhante ao } \\
\text { cerrado com herbáceo ralo com muita } \\
\text { Vochysia tucanorum e outras não } \\
\text { identificadas de } 8 \text { a } 10 \text { metros, estrato } \\
\text { herbáceo com Pteridófitas e muito } \\
\text { Gravatá. O cerrado senso estrito é } \\
\text { idem ao anterior com Qualea } \\
\text { parviflora. }\end{array}$ & $\begin{array}{l}\text { Cerrado senso estrito: Misto de } \\
\text { arvores secas e verdes, é um indicativo } \\
\text { da proximidade da rede de drenagem. } \\
\text { No estrato inferior presença de } \\
\text { Pteridófitas. Entre as plantas que tem } \\
\text { folhas verdes ocorrem muitos } \\
\text { indivíduos de Vochysia tucanorum. }\end{array}$ \\
\hline Ponto - 14 & & $\begin{array}{l}\text { Floresta ciliar: a feição desta } \\
\text { fisionomia se assemelha a do cerrado } \\
\text { com herbáceo ralo, porém esta } \\
\text { localizada bem na parte inferior do } \\
\text { vale, sobre a rede de drenagem. Dossel } \\
\text { continuo de } 6 \text { a } 8 \text { metros de altura, } \\
\text { muitas plântulas no estrato inferior. }\end{array}$ \\
\hline Ponto - 15 (GPS) & & $\begin{array}{l}\text { Campo cerrado: Predomínio de } \\
\text { Capim-gordura (Melinis minutiflora) no } \\
\text { estrato inferior e árvores esparsas de } \\
\text { Anadenanthera falcata. }\end{array}$ \\
\hline
\end{tabular}

\begin{tabular}{|c|c|c|c|}
\hline & Perfil Oeste - Lest & 20/01/97) & Perfil Oeste - Leste (13/08/96) \\
\hline Ponto - 01 (GPS) & Campo & Capim-gordura & Campo limpo: Partindo do fundo do \\
\hline
\end{tabular}




\begin{tabular}{|c|c|c|}
\hline & $\begin{array}{l}\text { (Melinis minutiflora), parcialmente } \\
\text { seco (com algumas rebrotas). }\end{array}$ & $\begin{array}{l}\text { vale na rede de drenagem, predomínio } \\
\text { de Capim-gordura (Melinis minutiflora) } \\
\text { e pequena mancha de Pteridium } \\
\text { aquilinum. Toda vegetação está seca. }\end{array}$ \\
\hline Ponto - 02 & $\begin{array}{l}\text { Campo limpo: } \text { Capim-gordura } \\
\text { (Melinis minutiflora), parcialmente } \\
\text { seco quase no limite com o Campo } \\
\text { Cerrado, poucos arbustos muito } \\
\text { esparsos. }\end{array}$ & $\begin{array}{l}\text { Campo cerrado: Bem no limite entre o } \\
\text { campo limpo e campo cerrado, aumento } \\
\text { na densidade de arbustos, mas ainda } \\
\text { ocorrem muito Campim-gordura } \\
\text { (Melinis minutiflora). Arbóreo } \\
\text { representado por Anadenanthera } \\
\text { falcata, mas muito esparsas. Toda a } \\
\text { vegetação está seca. }\end{array}$ \\
\hline Ponto - 03 & $\begin{array}{l}\text { Campo cerrado: Muito Ichnanthus } \\
\text { sericeus verde. Arbustos com até } 1,5 \\
\text { m de altura, Myrcia lingua e Bauhinia } \\
\text { rufa, Presença esparsa de } \\
\text { Anadenanthera falcata. }\end{array}$ & $\begin{array}{l}\text { Campo cerrado: Toda a vegetação } \\
\text { está muito seca (arbóreo e herbáceo). } \\
\text { Muito Ichnanthus sericeus e arbustos } \\
\text { como Bauhinia rufa. As arvores são } \\
\text { muito esparsas, Anadenanthera falcata. }\end{array}$ \\
\hline Ponto - 04 & $\begin{array}{l}\text { Campo cerrado: Diminuição do } \\
\text { Ichnanthus sericeus muitos arbustos } \\
\text { como Bauhinia rufa, Dimorphandra } \\
\text { mollis, Myrcia lingua e Aspidosperma } \\
\text { tomentosum. maior densidade de } \\
\text { árvores Anadenanthera falcata e } \\
\text { Copaifera langsdorfii, algumas } \\
\text { Banisteriopsis stellaris. } \\
\end{array}$ & $\begin{array}{l}\text { Campo cerrado: Anadenanthera } \\
\text { falcata muito esparsas, arbustos com } \\
\text { Bauhinia rufa, herbáceo com } \\
\text { Ichnanthus sericeus, todos com folhas } \\
\text { secas. }\end{array}$ \\
\hline Ponto - 05 & $\begin{array}{l}\text { Campo cerrado: Quase no limite } \\
\text { com Cerrado senso estrito, presença } \\
\text { de Ichnanthus sericeus e Arbustivo } \\
\text { com Byrsonima intermedia, Vatairea } \\
\text { macrocarpa, Pouteria torta, Bauhinia } \\
\text { rufa. Estrato arbóreo esparso mas } \\
\text { mais diversificado com Vochysia } \\
\text { tucanorum, Tocoyena formosa, } \\
\text { Anadenanthera falcata, Cariocar } \\
\text { brasiliensis, Hymenaea stigonocarpa. } \\
\text { Solo exposto em algumas áreas. }\end{array}$ & $\begin{array}{l}\text { Campo cerrado: presença de } \\
\text { Anadenanthera falcata muito esparsas, } \\
\text { arbustivo com muita Bauhinia rufa, } \\
\text { Pouteria torta e outras, estrato herbáceo } \\
\text { com predomínio de Capim-gordura } \\
\text { (Melinis minutiflora). Embora muito } \\
\text { seco algumas plantas tem algumas } \\
\text { folhas verdes (poucas). }\end{array}$ \\
\hline Pont & $\begin{array}{l}\text { Cerrado senso estrito: Estrato } \\
\text { herbáceo com presença de Ichnanthus } \\
\text { sericeus e começam a aparecer alguns } \\
\text { indivíduos de Rhyncospora exaltata. } \\
\text { arbustos de até } 2 \text { metros de altura em } \\
\text { grande densidade, arbóreo também } \\
\text { mais denso (Qualea parviflora, } \\
\text { Pouteria torta, Cariocar brasiliensis e } \\
\text { Myrcia lingua, presença de alguns } \\
\text { indivíduos de Banisteriopsis stellaris. }\end{array}$ & $\begin{array}{l}\text { Cerrado senso estrito: Parcialmente } \\
\text { seco. Arvores, arbusto e ervas } \\
\text { apresentam folhas secas e algumas } \\
\text { folhas verdes. Muitos arbustos, } \\
\text { herbáceo com Ichnanthus sericeus e } \\
\text { outras gramíneas em tufos } \\
\text { descontínuos. }\end{array}$ \\
\hline Ponto - 07 & $\begin{array}{l}\text { Cerrado senso estrito: Muitos } \\
\text { arbustos de } 1 \text { a } 2 \text { metros poucos } \\
\text { Ichnanthus sericeus, presença de } \\
\text { Byrsonima intermedia, Copaifera } \\
\text { langsdorfii, Xilopia aromatica e } \\
\text { Vochysia tucanorum e Pouteria torta, } \\
\text { muitos indivíduos de Banisteriopsis } \\
\text { stellaris. Arbóreo com Anadenanthera } \\
\text { falcata , Pouteria torta, Cariocar }\end{array}$ & $\begin{array}{l}\text { Cerrado senso estrito: No limite entre } \\
\text { o Campo cerrado e o Cerrado senso } \\
\text { estrito Aumento na densidade de } \\
\text { árvores e principalmente de arvoretas. } \\
\text { As plantas estão com com a maioria das } \\
\text { folhas verdes, algumas secas com } \\
\text { rebrotas sucessivas. }\end{array}$ \\
\hline
\end{tabular}




\begin{tabular}{|c|c|c|}
\hline & $\begin{array}{l}\text { brasiliensis, Vochysia tucanorum e } \\
\text { Pterodon pubescens. }\end{array}$ & \\
\hline Ponto - 08 & $\begin{array}{l}\text { Cerrado senso estrito: Tendência } \\
\text { para cerrado com herbáceo ralo, } \\
\text { ausência de Ichnanthus sericeus e } \\
\text { presença de Rhyncospora exaltata. } \\
\text { Dossel denso. Arbustivo com plantas } \\
\text { jovens, Arbóreo com Pterodon } \\
\text { pubescens, Anadenanthera falcata, } \\
\text { Pouteria torta, arvores com } 5 \text { a } 7 \\
\text { metro de altura mais densas, solo } \\
\text { mais sombreado. }\end{array}$ & $\begin{array}{l}\text { Cerrado senso estrito: A vegetação } \\
\text { está com as folhas verdes neste ponto. } \\
\text { Grande aumento na quantidade de } \\
\text { Banisteriopsis pubipetala, dossel } \\
\text { continuo de } 2 \text { a } 3 \text { metros de altura. Com } \\
\text { emergentes com } 7 \text { metros de altura. } \\
\text { Poucas gramineas ainda ocorrem, } \\
\text { Ichnanthus sericeus, começam a } \\
\text { aparecer indivíduos de Rhyncospora } \\
\text { exaltata. }\end{array}$ \\
\hline Ponto - 09 & $\begin{array}{l}\text { Cerrado com herbáceo ralo: Estrato } \\
\text { herbáceo quase ausente, poucas } \\
\text { Rhyncospora exaltata, muitas } \\
\text { plântulas. Dossel denso e uniforme } \\
\text { com } 4 \mathrm{~m} \text { e emergentes com } 7 \text { metros. } \\
\text { Muitos indivíduos de Xilopia } \\
\text { aromatica e Byrsonima intermedia. } \\
\text { Maior presença nas emergentes de } \\
\text { Pterodon pubescens e diminuição de } \\
\text { Anadenanthera falcata. }\end{array}$ & $\begin{array}{l}\text { Cerrado com herbáceo ralo: Esta no } \\
\text { limite entre Cerrado senso estrito e o } \\
\text { Cerrado com herbáceo ralo. Aumento } \\
\text { na densidade de Árvores e arvoretas. } \\
\text { Emergentes atingindo } 10 \text { metros e } \\
\text { dossel com } 5 \text { a } 6 \text { metros de altura. } \\
\text { Muitas Banisteriopsis pubipetala, } \\
\text { diminuição na quantidade de } \\
\text { gramíneas, inclusive poucos indivíduos } \\
\text { de Rhyncospora exaltata. }\end{array}$ \\
\hline Ponto - 10 & $\begin{array}{l}\text { Cerrado com herbáceo ralo: Estrato } \\
\text { herbáceo quase ausente, poucas } \\
\text { Rhyncospora exaltata e } \text { Syagrus } \\
\text { loefgrenii, muitas plântulas. Presença } \\
\text { de Strychnos bicolor, Virola sebifera } \\
\text { dossel denso e uniforme com } 5 \text { a } 7 \\
\text { metros, com Pterodon pubescens, } \\
\text { Anadenanthera falcata, Bauhinia } \\
\text { rufa, Copaifera langsdorfii. } \\
\text { serrapilheira presente, solo } \\
\text { sombreado. }\end{array}$ & $\begin{array}{l}\text { Cerrado com herbáceo ralo: Estrato } \\
\text { inferior com poucas Rhyncospora } \\
\text { exaltata e Syagrus loefgrenii, muitas } \\
\text { plântulas, dossel continuo com } 4 \text { a } 6 \\
\text { metros e emergentes com } 8 \text { a } 10 \text { metros. } \\
\text { As plantas jovens começam a } \\
\text { apresentar aspecto estiolado }\end{array}$ \\
\hline Ponto - 11 & $\begin{array}{l}\text { Cerrado com herbáceo ralo: } \\
\text { Rhyncospora exaltata muito esparsas, } \\
\text { muitas plântulas. Dossel continuo e } \\
\text { uniforme com } 5 \text { a } 7 \text { metros, com } \\
\text { Myrcia lingua, Virola sebifera, } \\
\text { Xilopia aromatica, Byrsonima } \\
\text { intermedia, Annona coriacea, } \\
\text { Roupala montana. Emergentes com } \\
10 \text { metros de altura Pterodon } \\
\text { pubescens e Anadenanthera falcata. } \\
\end{array}$ & $\begin{array}{l}\text { Cerrado com herbáceo ralo: Dossel } \\
\text { contínuo com } 5 \text { a } 6 \text { metros de altura. } \\
\text { Estrato inferior com poucas } \\
\text { Rhyncospora exaltata e muitas } \\
\text { plântulas, jovens com aspecto estiolado }\end{array}$ \\
\hline Ponto - 12 & $\begin{array}{l}\text { Cerrado com herbáceo ralo: Idem } \\
\text { anterior. }\end{array}$ & $\begin{array}{l}\text { Cerrado com herbáceo ralo: Dossel } \\
\text { continuo de } 6 \text { metros de altura, idem ao } \\
\text { ponto anterior. Ocorrência de Strychnos } \\
\text { bicolor esparsas. Presença de Amaioua } \\
\text { guianensis, Virola sebifera. Plântulas } \\
\text { jovens em grande quantidade. }\end{array}$ \\
\hline Ponto - 13 & \begin{tabular}{|l|l|} 
Cerrado com herbáceo ralo: & Idem \\
anterior, em alguns pontos mais \\
aberta tendendo a cerrado senso \\
estrito com ligeiro aumento na \\
quantidade de Rhyncospora exaltata.
\end{tabular} & $\begin{array}{l}\text { Cerrado com herbáceo ralo: Presença } \\
\text { de Emergentes de até } 15 \text { metros de } \\
\text { altura dossel de } 6 \text { a } 8 \text { metros, presença } \\
\text { de plantas escandentes como Strychnos } \\
\text { bicolor. Estrato inferior representado }\end{array}$ \\
\hline
\end{tabular}




\begin{tabular}{|c|c|c|}
\hline & $\begin{array}{l}\text { Dossel de } 4 \mathrm{~m} \text { e emergentes com } 7 \mathrm{~m} \\
\text { (Pterodon pubescens e Copaifera } \\
\text { langsdorfii). }\end{array}$ & $\begin{array}{l}\text { por Rhyncospora exaltata e muitas } \\
\text { plântulas. }\end{array}$ \\
\hline Ponto - 14 & $\begin{array}{l}\text { Cerrado com herbáceo ralo: Feição } \\
\text { assemelha-se a Cerrado senso estrito. } \\
\text { Aumento na quantidade de } \\
\text { Rhyncospora exaltata, dossel de } 4 \mathrm{~m} \\
\text { com emergentes de } 6 \mathrm{~m} \text {. Presença de } \\
\text { Strychnos bicolor. Cerrado com } \\
\text { herbáceo ralo com feição de cerrado } \\
\text { senso estrito. }\end{array}$ & $\begin{array}{l}\text { Cerrado com herbáceo ralo: Dossel de } \\
5 \text { metros de altura emergentes com } 7 \\
\text { metros. Estrato inferior com aumento } \\
\text { na densidade de Rhyncospora exaltata, } \\
\text { embora existam muitas plântulas. Alta } \\
\text { densidade de Arvoretas de } 5 \text { metros de } \\
\text { altura como (Myrcia lingua e outras). }\end{array}$ \\
\hline Ponto - 15 & $\begin{array}{l}\text { Cerrado com herbáceo ralo: Idem } \\
\text { anterior com emergentes de } 10 \mathrm{~m} \mathrm{de} \\
\text { altura (Pterodon pubescens). }\end{array}$ & $\begin{array}{l}\text { Cerrado com herbáceo ralo: Dossel de } \\
6 \text { a } 8 \text { metros de altura, muitas plantas } \\
\text { escandentes como Strychnos bicolor e } \\
\text { Bauhinia rufa. Estrato inferior com } \\
\text { plântulas e presença de Rhyncospora } \\
\text { exaltata (abundantes mas pouco } \\
\text { desenvolvidas). }\end{array}$ \\
\hline Ponto - 16 & $\begin{array}{l}\text { Cerrado com herbáceo ralo: Dossel } \\
\text { de } 5 \text { a } 6 \text { metros de } \\
\text { Pterodon pubescens, } \quad \text { Copaifera } \\
\text { langsdorfii, Byrsonima } \\
\text { Anadermedianthera falcata. Diminuição } \\
\text { do Strychnos bicolor, muita Miconia } \\
\text { albicans, Myrcia lingua e Xilopia } \\
\text { aromatica. }\end{array}$ & $\begin{array}{l}\text { Cerrado com herbáceo ralo: Dossel } \\
\text { variando de } 4 \text { a } 6 \text { metros e com } \\
\text { emergentes de } 7 \text { metros de altura. } \\
\text { Muitas plantas volventes e escandentes } \\
\text { secas como Strychnos bicolor. Estrato } \\
\text { inferior com Rhyncospora exaltata, } \\
\text { Syagrus loefgrenii e plântulas. }\end{array}$ \\
\hline Ponto - 17 & $\begin{array}{l}\text { Cerrado com herbáceo ralo: } \\
\text { /Cerradão: Dossel com } 7 \text { metros de } \\
\text { altura (Aspidosperma tomentosum, } \\
\text { Qualea grandiflora) e emergentes de } \\
12 \text { a } 15 \text { metros de altura (Pterodon } \\
\text { pubescens e Anadenanthera falcata). } \\
\text { Diminuição das Rhyncospora exaltata } \\
\text { e grande quantidade de plântulas. }\end{array}$ & $\begin{array}{l}\text { Cerrado com herbáceo ralo: Dossel } \\
\text { com } 4 \text { a } 6 \text { metros e emergentes de } 7 \\
\text { metros de altura. Encosta ingreme, } \\
\text { estrato inferior com muitas plântulas e } \\
\text { diminuição na quantidade de } \\
\text { Rhyncospora exaltata. }\end{array}$ \\
\hline Ponto - 18 & $\begin{array}{l}\text { Cerradão: ausência de de } \\
\text { Rhyncospora exaltata e presença de } \\
\text { Syagrus loefgrenii muito esparsas, } \\
\text { dossel continuo de } 6 \text { a } 7 \text { metros e } \\
\text { emergentes com } 15 \text { metros. Jovens } \\
\text { com caule reto e alongado o fuste e } \\
\text { projetado para o alto. O solo é bem } \\
\text { sombreado. }\end{array}$ & $\begin{array}{l}\text { Cerradão: Dossel contínuo com } 8 \text { a } 10 \\
\text { metros de altura. Plântulas esparsas, } \\
\text { estrato inferior muito ralo e esparso, } \\
\text { predominantemente com espessa } \\
\text { camada de serapilheira. Plantas jovens } \\
\text { com aspecto estiolado, solo bastante } \\
\text { sombreado. Presença de Virola sebifera, } \\
\text { Pterodon pubescens e Xilopia } \\
\text { aromatica atingindo o dossel superior. }\end{array}$ \\
\hline Ponto - 19 & \begin{tabular}{|l} 
Cerrado senso estrito: (fim do \\
cerradão limite é abrupto) dossel com \\
$4 \mathrm{~m}$ e emergentes com 6m (Pterodon \\
pubescens e Anadenanthera falcata) \\
grande quantidade de Banisteriopsis \\
stellaris e Xilopia aromatica com 2 a \\
3 metros. Aparecimento de \\
Rhyncospora exaltata
\end{tabular} & $\begin{array}{l}\text { Cerrado senso estrito: Fim do } \\
\text { Cerradão e início do Cerrado senso } \\
\text { estrito. Ocorrência de árvores esparsas, } \\
\text { aumento na quantidade de de } \\
\text { Banisteriopsis pubipetala. Dossel } \\
\text { descontínuo de } 3 \text { a } 4 \text { metros com } \\
\text { emergentes de } 6 \text { a } 8 \text { metros de altura. } \\
\text { Aumento na quntidade de arbustos, } \\
\text { presença de Rhyncospora exaltata e } \\
\text { Capim-gordura (Melinis minutiflora) } \\
\text { começa aparecer. }\end{array}$ \\
\hline Ponto - 20 & Cerrado senso estrito: Dossel com 2 & Cerrado senso estrito: Dossel com 2 \\
\hline
\end{tabular}




\begin{tabular}{|c|c|c|}
\hline & $\begin{array}{l}\text { a } 4 \text { metros (Pouteria torta, Miconia } \\
\text { albicans, Dalbergia miscolobium, } \\
\text { Pterodon pubescens, Bauhinia rufa) } \\
\text { emergentes com 6m (Anadenanthera } \\
\text { falcata e Stryphnodendron } \\
\text { adstringens) grande quantidade de } \\
\begin{array}{l}\text { Rhyncospora exaltata e Ichnanthus } \\
\text { sericeus }\end{array}\end{array}$ & $\begin{array}{l}\text { metros de altura composto de arvoretas, } \\
\text { árvores descontinuas de } 6 \text { a } 8 \text { metros. } \\
\text { Estrato arbustivo e herbáceo com folhas } \\
\text { mistas secas e verdes. }\end{array}$ \\
\hline Ponto - 21 & $\begin{array}{l}\text { Cerrado senso estrito: /Campo } \\
\text { cerrado: Dossel com } 2 \text { a } 1,5 \mathrm{~m} \text { com } \\
\text { emergentes de até } 6 \mathrm{~m} \text {. Presença de } \\
\text { Ichnanthus sericeus. Muitos arbustos } \\
\text { em estado de rebrota (rebrotas } \\
\text { sucessivas), como Aspidosperma } \\
\text { tomentosum, Pouteria torta e } \\
\text { Bauhinia rufa, como emergentes estão } \\
\text { Pterodon pubescens e Anadenanthera } \\
\text { falcata. Feição próxima a do Campo } \\
\text { Cerrado. }\end{array}$ & $\begin{array}{l}\text { Campo cerrado: Vegetação com } \\
\text { folhas secas, poucas folhas verdes } \\
\text { arvores esparsas e secas e com poucas } \\
\text { folhas verdes (com rebrotas sucessivas). } \\
\text { Muitos arbustos, estrato inferior com } \\
\text { muitas gramíneas em tufos contínuos }\end{array}$ \\
\hline Ponto - 22 & $\begin{array}{l}\text { Campo cerrado: Grande quantidade } \\
\text { de Capim-flecha (Tristachya } \\
\text { leiostachya) e Ichnanthus sericeus, } \\
\text { poucas Rhyncospora exaltata ainda } \\
\text { persistem, arbustos com rebrotas } \\
\text { sucessivas (Pouteria torta, Vochysia } \\
\text { tucanorum, Byrsonima intermedia e } \\
\text { Bauhinia rufa) emergente somente a } \\
\text { Anadenanthera falcata com 6m } \\
\text { (tambem com rebrotas sucessivas). }\end{array}$ & 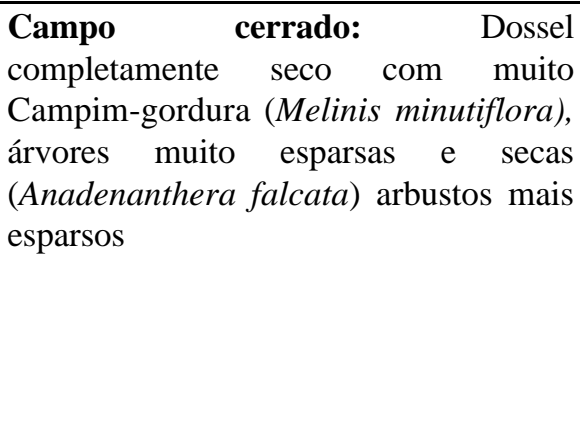 \\
\hline Ponto - 23 & $\begin{array}{l}\text { Campo cerrado: Grande quantidade } \\
\text { e aumento de riquesa do estrato } \\
\text { herbáceo como Capim-flecha } \\
\text { (Tristachya leiostachya), Ichnanthus } \\
\text { sericeus, Capim-gordura (Melinis } \\
\text { minutiflora), ausência Rhyncospora } \\
\text { exaltata), estrato arbustivo de } 1 \mathrm{~m} \text { a } \\
2 \mathrm{~m} \text { com Didymopanax vinosum, } \\
\text { Vatairea macrocarpa e poucas } \\
\text { Bauhinia rufa. }\end{array}$ & $\begin{array}{lll}\text { Campo } & \text { cerrado: } & \text { Dossel } \\
\text { completamente seco arvores esparsas e } \\
\text { predomínio de arbusto de } 1,5 \text { a } 2 \text { metros } \\
\text { de altura. Gramineas ocorrem em tufos } \\
\text { descontínuos }\end{array}$ \\
\hline Ponto - 24 (GPS) & & $\begin{array}{l}\text { Campo cerrado: Idem ao anterior, } \\
\text { porém começaram a aparecer algumas } \\
\text { folhas verdes. Ponto muito próximo a } \\
\text { rede de drenagem (fundo do vale). }\end{array}$ \\
\hline
\end{tabular}


Tabela 10.5. - Dados de campo utilizados para fazer o ajuste da superfície (imagem MDT com resolução de 10m x 10m) das transeções sobre o morro, com as imagens IVDN com resolução de 30m x 30m.

\begin{tabular}{|c|c|c|c|c|c|c|c|}
\hline $\begin{array}{l}\text { Imag. } \\
10 \times 10\end{array}$ & Altitude & $\begin{array}{l}\text { Dist. Ajust. } \\
\text { Superfic. }\end{array}$ & $\begin{array}{l}\text { Imag. } \\
30 \times 30\end{array}$ & Ponto & $\begin{array}{c}\text { Agosto } 96 \\
(\mathrm{~N}-\mathrm{S})\end{array}$ & $\begin{array}{c}\text { Janeiro } 97 \\
(\mathrm{~N}-\mathrm{S})\end{array}$ & Média \\
\hline 1 & 630 & 10 & 1 & & $\mathrm{Cc}(\operatorname{seco})$ & $\mathrm{Cc}$ & $\mathrm{Cc}$ \\
\hline 2 & 630 & 21 & 1 & & $\mathrm{Cc}(\mathrm{seco})$ & $\mathrm{Cc}$ & \\
\hline 3 & 630 & 31 & 1 & & $\mathrm{Cc}(\operatorname{seco})$ & $\mathrm{Cc}$ & \\
\hline 4 & 630 & 42 & 2 & & $\mathrm{Cc}(\mathrm{seco})$ & $\mathrm{Cc}$ & $\mathrm{Cc}$ \\
\hline 5 & 630 & 52 & 2 & 1 & $\mathrm{Cc}(\operatorname{seco})$ & $\mathrm{Cc}$ & \\
\hline 6 & 630 & 63 & 2 & & $\mathrm{Cc}(\operatorname{seco})$ & $\mathrm{Cc}$ & \\
\hline 7 & 631 & 73 & 3 & & $\mathrm{Cc}(\operatorname{seco})$ & $\mathrm{Cc}$ & $\mathrm{Cc}$ \\
\hline 8 & 631 & 84 & 3 & & $\mathrm{Cc}(\mathrm{seco})$ & $\mathrm{Cc}$ & \\
\hline 9 & 632 & 94 & 3 & & $\mathrm{Cc}(\operatorname{seco})$ & $\mathrm{Cc}$ & \\
\hline 10 & 632 & 105 & 4 & 2 & $\mathrm{Cc}(\operatorname{seco})$ & $\mathrm{Cc}$ & $\mathrm{Cc}$ \\
\hline 11 & 633 & 115 & 4 & & $\mathrm{Cc}(\mathrm{seco})$ & $\mathrm{Cc}$ & \\
\hline 12 & 634 & 126 & 4 & & $\mathrm{Cc}(\mathrm{seco})$ & $\mathrm{Cc}$ & \\
\hline 13 & 634 & 136 & 5 & & $\mathrm{Cc}(\mathrm{seco})$ & $\mathrm{Cc}$ & $\mathrm{Cc} / \mathrm{Ce}$ \\
\hline 14 & 635 & 147 & 5 & & $\mathrm{Ce}(\operatorname{seco})$ & $\mathrm{Cc}$ & \\
\hline 15 & 637 & 157 & 5 & 3 & $\mathrm{Ce}(\mathrm{seco})$ & $\mathrm{Ce}$ & \\
\hline 16 & 638 & 168 & 6 & & $\mathrm{Ce}(\mathrm{seco})$ & $\mathrm{Ce}$ & $\mathrm{Ce}$ \\
\hline 17 & 638 & 179 & 6 & & $\mathrm{Ce}(\mathrm{seco})$ & $\mathrm{Ce}$ & \\
\hline 18 & 640 & 189 & 6 & & $\mathrm{Ce}$ (verde) & $\mathrm{Ce}$ & \\
\hline 19 & 643 & 200 & 7 & & $\mathrm{Ce}$ (verde) & $\mathrm{Ce}$ & $\mathrm{Ce}$ \\
\hline 20 & 645 & 211 & 7 & 4 & $\mathrm{Ce}$ (verde) & $\mathrm{Ce}$ & \\
\hline 21 & 647 & 221 & 7 & & Ce (verde) & $\mathrm{Ce}$ & \\
\hline 22 & 648 & 232 & 8 & & $\mathrm{Ce}$ (verde) & $\mathrm{Ch}$ & $\mathrm{Ce} / \mathrm{Ch}$ \\
\hline 23 & 648 & 242 & 8 & & Ch (verde) & $\mathrm{Ch}$ & \\
\hline 24 & 650 & 253 & 8 & 5 & Ch (verde) & $\mathrm{Ch}$ & \\
\hline 25 & 655 & 265 & 9 & & Ch (verde) & $\mathrm{Ch}$ & $\mathrm{Ch}$ \\
\hline 26 & 655 & 275 & 9 & & Ch (verde) & $\mathrm{Ch}$ & \\
\hline 27 & 660 & 287 & 9 & & Ch (verde) & $\mathrm{Ch}$ & \\
\hline 28 & 665 & 298 & 10 & & Ch (verde) & $\mathrm{Ch}$ & $\mathrm{Ch}$ \\
\hline 29 & 665 & 309 & 10 & 6 & Ch (verde) & $\mathrm{Ch}$ & \\
\hline 30 & 668 & 319 & 10 & & Ch (verde) & $\mathrm{Ch}$ & \\
\hline 31 & 670 & 330 & 11 & & Ch (verde) & $\mathrm{Ch}$ & $\mathrm{Ch}$ \\
\hline 32 & 673 & 341 & 11 & & Ch (verde) & $\mathrm{Ch}$ & \\
\hline 33 & 673 & 351 & 11 & 7 & Ch (verde) & $\mathrm{Ch}$ & \\
\hline 34 & 675 & 362 & 12 & & Ch (verde) & $\mathrm{Ch}$ & $\mathrm{Ch}$ \\
\hline 35 & 673 & 373 & 12 & & Ch (verde) & $\mathrm{Ch}$ & \\
\hline 36 & 673 & 383 & 12 & & Ch (verde) & $\mathrm{Ch}$ & \\
\hline 37 & 673 & 394 & 13 & & Ch (verde) & $\mathrm{Ch}$ & $\mathrm{Ch}$ \\
\hline 38 & 671 & 404 & 13 & 8 & Ch (verde) & $\mathrm{Ch}$ & \\
\hline 39 & 670 & 415 & 13 & & Ch (verde) & $\mathrm{Ch}$ & \\
\hline 40 & 670 & 425 & 14 & & Cd (verde) & $\mathrm{Cd}$ & $\mathrm{Cd}$ \\
\hline 41 & 665 & 437 & 14 & & $\mathrm{Cd}$ (verde) & $\mathrm{Cd}$ & \\
\hline 42 & 665 & 447 & 14 & & Cd (verde) & $\mathrm{Cd}$ & \\
\hline 43 & 665 & 458 & 15 & 9 & Cd (verde) & $\mathrm{Cd}$ & $\mathrm{Cd}$ \\
\hline 44 & 660 & 470 & 15 & & Cd (verde) & $\mathrm{Cd}$ & \\
\hline 45 & 660 & 480 & 15 & & $\mathrm{Cd}$ (verde) & $\mathrm{Cd}$ & \\
\hline 46 & 660 & 490 & 16 & & Ce (verde) & $\mathrm{Ce}$ & $\mathrm{Ce}$ \\
\hline 47 & 655 & 502 & 16 & 10 & Ce (verde) & $\mathrm{Ce}$ & \\
\hline 48 & 650 & 514 & 16 & & $\mathrm{Ce}$ (verde) & $\mathrm{Ce}$ & \\
\hline 49 & 650 & 524 & 17 & & $\mathrm{Ce}$ (verde) & $\mathrm{Ce}$ & $\mathrm{Ce}$ \\
\hline
\end{tabular}




\begin{tabular}{|c|c|c|c|c|c|c|c|}
\hline 50 & 645 & 536 & 17 & & $\mathrm{Ce}(\mathrm{seco})$ & $\mathrm{Ce}$ & \\
\hline 51 & 645 & 546 & 17 & & $\mathrm{Ce}(\operatorname{seco})$ & $\mathrm{Ce}$ & \\
\hline 52 & 643 & 557 & 18 & 11 & $\mathrm{Ce}(\mathrm{seco})$ & $\mathrm{Ce}$ & $\mathrm{Ce}$ \\
\hline 53 & 640 & 568 & 18 & & $\mathrm{Ce}(\mathrm{seco})$ & $\mathrm{Ce}$ & \\
\hline 54 & 638 & 578 & 18 & & $\mathrm{Ce}(\mathrm{seco})$ & $\mathrm{Ce}$ & \\
\hline 55 & 638 & 589 & 19 & & $\mathrm{Ce}(\mathrm{seco})$ & $\mathrm{Ce} / \mathrm{Cc}$ & $\mathrm{Ce}$ \\
\hline 56 & 638 & 599 & 19 & & $\mathrm{Ce}(\operatorname{seco})$ & $\mathrm{Ce} / \mathrm{Cc}$ & \\
\hline 57 & 635 & 610 & 19 & 12 & $\mathrm{Ce}(\mathrm{seco})$ & $\mathrm{Ce} / \mathrm{Cc}$ & \\
\hline 58 & 635 & 621 & 20 & & $\mathrm{Ce}(\mathrm{seco})$ & $\mathrm{Ce}$ & $\mathrm{Ce}$ \\
\hline 59 & 634 & 631 & 20 & & $\begin{array}{c}\mathrm{Ce} \\
\text { (seco/verde) }\end{array}$ & $\mathrm{Ce}$ & \\
\hline 60 & 633 & 642 & 20 & & $\begin{array}{c}\mathrm{Ce} \\
\text { (seco/verde) } \\
\end{array}$ & $\mathrm{Ce}$ & \\
\hline 61 & 633 & 652 & 21 & 13 & $\begin{array}{c}\mathrm{Ce} \\
\text { (seco/verde) }\end{array}$ & $\mathrm{Fc}$ & $\mathrm{Ce} / \mathrm{Fc}$ \\
\hline 62 & 633 & 663 & 21 & & $\begin{array}{c}\mathrm{Ce} \\
\text { (seco/verde) }\end{array}$ & $\mathrm{Fc}$ & \\
\hline 63 & 631 & 673 & 21 & & $\begin{array}{c}\mathrm{Ce} \\
\text { (seco/verde) }\end{array}$ & $\mathrm{Fc}$ & \\
\hline 64 & 630 & 684 & 22 & & $\begin{array}{c}\mathrm{Ce} \\
\text { (seco/verde) }\end{array}$ & $\mathrm{Fc}$ & $\mathrm{Fc}$ \\
\hline 65 & 630 & 694 & 22 & & Fc (verde) & $\mathrm{Fc}$ & \\
\hline 66 & 630 & 705 & 22 & 14 & Fc (verde) & & \\
\hline 67 & 630 & 715 & 23 & & Fc (verde) & & $\mathrm{Fc} / \mathrm{Cc}$ \\
\hline 68 & 630 & 726 & 23 & & Fc (verde) & & \\
\hline 69 & 630 & 736 & 23 & & Cc $(\operatorname{seco})$ & & \\
\hline 70 & 630 & 747 & 24 & & $\mathrm{Cc}(\operatorname{seco})$ & & $\mathrm{Cc}$ \\
\hline 71 & 630 & 757 & 24 & 15 & Cc (seco) & & \\
\hline 72 & 630 & 768 & 24 & & $\mathrm{Cc}(\mathrm{seco})$ & & \\
\hline 73 & 630 & 778 & 25 & & $\mathrm{Cc}(\mathrm{seco})$ & & $\mathrm{Cc}$ \\
\hline 74 & 630 & 789 & 25 & & & & \\
\hline 75 & 630 & 799 & 25 & & & & \\
\hline
\end{tabular}

\begin{tabular}{|c|c|c|c|c|c|c|c|}
\hline $\begin{array}{l}\text { Imag. } \\
10 \times 10\end{array}$ & Altitude & $\begin{array}{c}\text { Dist. Ajust. } \\
\text { Superfic. }\end{array}$ & $\begin{array}{l}\text { Imag. } \\
\text { 30x30 }\end{array}$ & Ponto & $\begin{array}{c}\text { Agosto } 96 \\
\text { (O-L) }\end{array}$ & $\begin{array}{c}\text { Janeiro } 97 \\
\text { (O-L) }\end{array}$ & Média \\
\hline 1 & 625 & & 1 & & & & \\
\hline 2 & 625 & & 1 & & & & \\
\hline 3 & 625 & & 1 & & & & \\
\hline 4 & 625 & & 2 & & & & \\
\hline 5 & 625 & & 2 & & & & \\
\hline 6 & 625 & & 2 & & & & \\
\hline 7 & 625 & 11 & 3 & & $\mathrm{Cp}(\operatorname{seco})$ & $\mathrm{Cp}$ & $\mathrm{Cp}$ \\
\hline 8 & 625 & 22 & 3 & & $\mathrm{Cp}(\operatorname{seco})$ & $\mathrm{Cp}$ & \\
\hline 9 & 625 & 33 & 3 & 1 & $\mathrm{Cp}(\operatorname{seco})$ & $\mathrm{Cp}$ & \\
\hline 10 & 625 & 44 & 4 & & $\mathrm{Cp}(\operatorname{seco})$ & $\mathrm{Cp}$ & $\mathrm{Cp}$ \\
\hline 11 & 625 & 55 & 4 & & $\mathrm{Cp}$ (seco) & $\mathrm{Cp}$ & \\
\hline 12 & 625 & 66 & 4 & 2 & $\mathrm{Cp}(\operatorname{seco})$ & $\mathrm{Cp}$ & \\
\hline 13 & 627 & 77 & 5 & & $\mathrm{Cc}(\operatorname{seco})$ & $\mathrm{Cc}$ & $\mathrm{Cc}$ \\
\hline 14 & 628 & 88 & 5 & & $\mathrm{Cc}(\operatorname{seco})$ & $\mathrm{Cc}$ & \\
\hline 15 & 630 & 99 & 5 & 3 & $\mathrm{Cc}(\operatorname{seco})$ & $\mathrm{Cc}$ & \\
\hline 16 & 631 & 111 & 6 & & $\mathrm{Cc}(\mathrm{seco})$ & $\mathrm{Cc}$ & $\mathrm{Cc}$ \\
\hline 17 & 632 & 122 & 6 & 4 & $\mathrm{Cc}(\operatorname{seco})$ & $\mathrm{Cc}$ & \\
\hline 18 & 634 & 133 & 6 & & $\mathrm{Cc}(\mathrm{seco})$ & $\mathrm{Cc}$ & \\
\hline 19 & 635 & 144 & 7 & & $\mathrm{Cc}(\operatorname{seco})$ & $\mathrm{Cc}$ & $\mathrm{Cc}$ \\
\hline 20 & 637 & 155 & 7 & 5 & $\begin{array}{c}\mathrm{Cc} \\
\text { (seco/verde) }\end{array}$ & $\mathrm{Cc}$ & \\
\hline 21 & 640 & 166 & 7 & & $\begin{array}{c}\mathrm{Cc} \\
\text { (seco/verde) }\end{array}$ & $\mathrm{Cc}$ & \\
\hline
\end{tabular}




\begin{tabular}{|c|c|c|c|c|c|c|c|}
\hline 22 & 642 & 178 & 8 & & $\begin{array}{c}\mathrm{Cc} \\
\text { (seco/verde) }\end{array}$ & $\mathrm{Cc}$ & $\mathrm{Cc} / \mathrm{Ce}$ \\
\hline 23 & 645 & 189 & 8 & 6 & $\begin{array}{c}\mathrm{Cc} \\
\text { (seco/verde) }\end{array}$ & $\mathrm{Ce}$ & \\
\hline 24 & 647 & 200 & 8 & & $\begin{array}{c}\mathrm{Ce} \\
\text { (seco/verde) }\end{array}$ & $\mathrm{Ce}$ & \\
\hline 25 & 648 & 211 & 9 & 7 & $\begin{array}{c}\mathrm{Ce} \\
\text { (seco/verde) }\end{array}$ & $\mathrm{Ce}$ & $\mathrm{Ce}$ \\
\hline 26 & 650 & 222 & 9 & & $\begin{array}{c}\mathrm{Ce} \\
\text { (seco/verde) }\end{array}$ & $\mathrm{Ce}$ & \\
\hline 27 & 652 & 234 & 9 & & $\mathrm{Ce}$ (verde) & $\mathrm{Ce}$ & \\
\hline 28 & 652 & 245 & 10 & 8 & $\mathrm{Ce}$ (verde) & $\mathrm{Ce}$ & $\mathrm{Ce}$ \\
\hline 29 & 655 & 256 & 10 & & $\mathrm{Ce}$ (verde) & $\mathrm{Ce}$ & \\
\hline 30 & 657 & 267 & 10 & & $\mathrm{Ce}$ (verde) & $\mathrm{Ce}$ & \\
\hline 31 & 658 & 278 & 11 & 9 & $\mathrm{Ce}$ (verde) & $\mathrm{Ch}$ & $\mathrm{Ce} / \mathrm{Ch}$ \\
\hline 32 & 660 & 290 & 11 & & Ch (verde) & $\mathrm{Ch}$ & \\
\hline 33 & 661 & 301 & 11 & 10 & Ch (verde) & $\mathrm{Ch}$ & \\
\hline 34 & 662 & 312 & 12 & & Ch (verde) & $\mathrm{Ch}$ & $\mathrm{Ch}$ \\
\hline 35 & 663 & 323 & 12 & & Ch (verde) & $\mathrm{Ch}$ & \\
\hline 36 & 663 & 334 & 12 & 11 & Ch (verde) & $\mathrm{Ch}$ & \\
\hline 37 & 665 & 345 & 13 & & Ch (verde) & $\mathrm{Ch}$ & $\mathrm{Ch}$ \\
\hline 38 & 666 & 356 & 13 & & Ch (verde) & $\mathrm{Ch}$ & \\
\hline 39 & 666 & 367 & 13 & 12 & Ch (verde) & $\mathrm{Ch}$ & \\
\hline 40 & 667 & 378 & 14 & & Ch (verde) & $\mathrm{Ch}$ & $\mathrm{Ch}$ \\
\hline 41 & 668 & 389 & 14 & & Ch (verde) & $\mathrm{Ch}$ & \\
\hline 42 & 670 & 400 & 14 & 13 & Ch (verde) & $\mathrm{Ch}$ & \\
\hline 43 & 672 & 411 & 15 & & Ch (verde) & $\mathrm{Ch}$ & $\mathrm{Ch}$ \\
\hline 44 & 675 & 423 & 15 & 14 & Ch (verde) & $\mathrm{Ch}$ & \\
\hline 45 & 675 & 434 & 15 & & Ch (verde) & $\mathrm{Ch}$ & \\
\hline 46 & 675 & 445 & 16 & & Ch (verde) & $\mathrm{Ch}$ & $\mathrm{Ch}$ \\
\hline 47 & 675 & 456 & 16 & 15 & Ch (verde) & $\mathrm{Ch}$ & \\
\hline 48 & 672 & 467 & 16 & & Ch (verde) & $\mathrm{Ch}$ & \\
\hline 49 & 670 & 478 & 17 & & Ch (verde) & $\mathrm{Ch}$ & $\mathrm{Ch}$ \\
\hline 50 & 670 & 489 & 17 & 16 & Ch (verde) & $\mathrm{Ch}$ & \\
\hline 51 & 665 & 502 & 17 & & Ch (verde) & $\mathrm{Ch}$ & \\
\hline 52 & 665 & 513 & 18 & 17 & Ch (verde) & $\mathrm{Ch}$ & $\mathrm{Ch} / \mathrm{Cd}$ \\
\hline 53 & 660 & 525 & 18 & & $\mathrm{Cd}$ (verde) & $\mathrm{Ch}$ & \\
\hline 54 & 655 & 537 & 18 & & $\mathrm{Cd}$ (verde) & $\mathrm{Cd}$ & \\
\hline 55 & 655 & 548 & 19 & 18 & $\mathrm{Cd}$ (verde) & $\mathrm{Cd}$ & $\mathrm{Cd}$ \\
\hline 56 & 650 & 560 & 19 & & Cd (verde) & $\mathrm{Cd}$ & \\
\hline 57 & 650 & 571 & 19 & 19 & $\mathrm{Ce}$ (verde) & $\mathrm{Cd}$ & \\
\hline 58 & 647 & 582 & 20 & & $\mathrm{Ce}$ (verde) & $\mathrm{Ce}$ & $\mathrm{Ce}$ \\
\hline 59 & 645 & 593 & 20 & & $\mathrm{Ce}$ (verde) & $\mathrm{Ce}$ & \\
\hline 60 & 644 & 605 & 20 & 20 & $\mathrm{Ce}$ (verde) & $\mathrm{Ce}$ & \\
\hline 61 & 643 & 616 & 21 & & $\mathrm{Ce}$ (verde) & $\mathrm{Ce}$ & $\mathrm{Ce} / \mathrm{Cc}$ \\
\hline 62 & 642 & 627 & 21 & & $\begin{array}{c}\mathrm{Cc} \\
\text { (seco/verde) }\end{array}$ & $\mathrm{Ce}$ & \\
\hline 63 & 641 & 638 & 21 & 21 & $\begin{array}{c}\mathrm{Cc} \\
\text { (seco/verde) }\end{array}$ & $\mathrm{Ce}$ & \\
\hline 64 & 640 & 649 & 22 & & $\begin{array}{c}\mathrm{Cc} \\
\text { (seco/verde) }\end{array}$ & $\mathrm{Cc}$ & $\mathrm{Cc}$ \\
\hline 65 & 639 & 660 & 22 & 22 & $\mathrm{Cc}(\operatorname{seco})$ & $\mathrm{Cc}$ & \\
\hline 66 & 638 & 671 & 22 & & $\mathrm{Cc}(\mathrm{seco})$ & & \\
\hline 67 & 638 & 682 & 23 & & $\mathrm{Cc}(\operatorname{seco})$ & & $\mathrm{Cc}$ \\
\hline 68 & 636 & 693 & 23 & 23 & Cc ( $\operatorname{seco})$ & & \\
\hline 69 & 636 & 704 & 23 & & $\mathrm{Cc}(\operatorname{seco})$ & & \\
\hline 70 & 636 & 715 & 24 & 24 & Cc (seco) & & $\mathrm{Cc}$ \\
\hline 71 & 636 & 726 & 24 & & Cc (seco) & & \\
\hline
\end{tabular}




\begin{tabular}{|l|l|l|l|l|l|l|l|}
\hline 72 & 637 & 737 & 24 & & Cc (seco) & & \\
\hline 73 & 639 & 748 & 25 & & & & \\
\hline 74 & 639 & 759 & 25 & & & & \\
\hline 75 & 639 & 770 & 25 & & & & \\
\hline
\end{tabular}

$\mathrm{Cu}=$ Campo úmido; $\mathrm{Cp}=$ Campo limpo; $\mathrm{Cc}=$ Campo cerrado; $\mathrm{Ce}=$ Cerrado senso estrito; $\mathrm{Ch}=$ Cerrado com herbáceo ralo; $\mathrm{Cd}=$ Cerradão e $\mathrm{Fc}=$ Floresta ciliar.

Tabela 10.6. - Cor do solo seco e úmido, a textura (medida grosseira) e a fitofisionomia onde foi coletada a amostra.

\begin{tabular}{|c|c|c|c|c|}
\hline Amostra & Cor (seco) & Cor (úmido) & Textura & Fitofisionomia \\
\hline 1 & $5 \mathrm{YR} 4 / 3$ & $5 \mathrm{YR} 2,5 / 2$ & $\mathrm{G}$ & Floresta estacional semidecidual \\
\hline 2 & $5 \mathrm{YR} 4 / 6$ & $5 \mathrm{YR} 3 / 3$ & $\mathrm{~F}$ & Cerradão \\
\hline 3 & 2,5YR 5/4 & 2,5YR 3/4 & $\mathrm{M}$ & Cerrado com herbáceo ralo \\
\hline 4 & 5YR 5/4 & $5 \mathrm{YR} 3 / 2$ & $\mathrm{M}$ & Cerrado senso estrito \\
\hline 5 & $5 \mathrm{YR} 4 / 6$ & $5 \mathrm{YR} 3 / 3$ & $\mathrm{~F}$ & Cerrado senso estrito \\
\hline 6 & $5 \mathrm{YR} 6 / 4$ & $5 \mathrm{YR} 3 / 3$ & $\mathrm{M}$ & Cerrado senso estrito \\
\hline 7 & $5 \mathrm{YR} 5 / 3$ & $5 \mathrm{YR} 3 / 2$ & $\mathrm{M}$ & Cerrado senso estrito \\
\hline 8 & 7,5YR 6/4 & 7,5YR 3/4 & $\mathrm{M}$ & Campo cerrado \\
\hline 9 & $2,5 \mathrm{YR} 4 / 8$ & 2,5YR 3/6 & $\mathrm{F}$ & Campo sujo \\
\hline 10 & 7,5YR 7/0 & 7,5 YR $2 / 0$ & $\mathrm{G}$ & Campo úmido \\
\hline 11 & 7,5YR 7/6 & 7,5YR 4/4 & $\mathrm{G}$ & Campo cerrado \\
\hline 12 & $5 Y R 7 / 4$ & 5 YR 5/4 & $\mathrm{M}$ & Campo limpo \\
\hline 13 & 10YR 7/2 & $10 \mathrm{YR} 3 / 2$ & $\mathrm{G}$ & Campo cerrado \\
\hline 14 & 10YR 4/1 & $7,5 \mathrm{YR} 2 / 0$ & $\mathrm{M}$ & Campo úmido \\
\hline 15 & 7,5YR 6/4 & 7,5YR 3/4 & $\mathrm{M}$ & Campo cerrado \\
\hline 16 & 5 YR 6/6 & $5 Y R 4 / 4$ & $\mathrm{M}$ & Cerrado senso estrito \\
\hline 17 & $5 Y R 6 / 4$ & $5 Y R 4 / 4$ & $\mathrm{M}$ & Campo cerrado \\
\hline 18 & $5 Y R 6 / 4$ & $5 Y R 3 / 3$ & $\mathrm{M}$ & Campo cerrado \\
\hline 19 & 10YR 7/1 & 10YR 5/1 & $\mathrm{G}$ & Campo úmido \\
\hline 20 & 7,5YR 4/4 & 7,5YR 3/2 & $\mathrm{G}$ & Campo cerrado \\
\hline 21 & 2,5 YR $6 / 4$ & 2,5YR3/6 & $\mathrm{M}$ & Campo cerrado \\
\hline 22 & $10 \mathrm{YR} 6 / 2$ & 10YR $3 / 2$ & $\mathrm{M}$ & Campo cerrado \\
\hline 23 & $2,5 \mathrm{YR} 4 / 6$ & $2,5 \mathrm{YR} 3 / 4$ & $\mathrm{M}$ & Campo cerrado \\
\hline 24 & 2,5YR 5/6 & 2,5YR 3/6 & $\mathrm{F}$ & Campo cerrado \\
\hline 25 & 5YR 5/6 & 2,5YR 3/6 & $\mathrm{F}$ & Campo cerrado \\
\hline 26 & $5 Y R 4 / 4$ & 5 YR $3 / 2$ & $\mathrm{M}$ & Campo úmido \\
\hline 27 & 5 YR 6/6 & $2,5 \mathrm{YR} 4 / 6$ & $\mathrm{~F}$ & Campo cerrado \\
\hline 28 & 2,5 YR 5/6 & $2,5 Y R \quad 3 / 4$ & $\mathrm{~F}$ & Cerrado senso estrito \\
\hline 29 & 2,5 YR $5 / 8$ & 2,5 YR $3 / 6$ & $\mathrm{~F}$ & Campo cerrado \\
\hline 30 & $5 \mathrm{YR} 4 / 4$ & $5 \mathrm{YR} 2,5 / 2$ & $\mathrm{M}$ & Campo cerrado \\
\hline 31 & 2,5 YR $5 / 6$ & 2,5 YR $3 / 6$ & $\mathrm{~F}$ & Campo limpo \\
\hline 32 & 5YR 4/4 & $2,5 \mathrm{YR} 2,5 / 4$ & $\mathrm{M}$ & Campo úmido \\
\hline 33 & 2,5 YR $5 / 6$ & $2,5 \mathrm{YR} 4 / 4$ & $\mathrm{~F}$ & Campo cerrado \\
\hline 34 & $10 \mathrm{YR} 7 / 2$ & $10 \mathrm{YR} 4 / 2$ & $\mathrm{G}$ & Campo cerrado \\
\hline 35 & 5 YR 5/6 & $5 Y R 3 / 4$ & $\mathrm{M}$ & Campo cerrado \\
\hline 36 & 5 YR 5/4 & $5 \mathrm{YR} 3 / 3$ & $\mathrm{M}$ & Campo cerrado \\
\hline 37 & 5 YR $5 / 3$ & 5YR 3/2 & $\mathrm{M}$ & Campo úmido \\
\hline
\end{tabular}


Tabela 10.7. - Média e o desvio padrão extraídos das áreas de ocorrência, obtidas a partir das imagens: IVDN, faixa do vermelho, do infravermelho próximo e do infravermelho médio.

\begin{tabular}{|c|c|c|c|c|c|}
\hline Faixa do Vermelho & agosto95 & janeiro96 & julho95 & junho97 & julho96 \\
\hline Campo Úmido & 0.0770 .006 & 0.0540 .008 & 0.0670 .006 & 0.0510 .009 & 0.0770 .009 \\
\hline Campo Limpo (Melinis) & 0.0650 .005 & $0.0420 .005 \quad c$ & 0.0490 .007 & $0.0380 .006 \quad c$ & 0.0620 .009 \\
\hline Campo (Pteridium) & 0.0650 .003 & 0.0420 .002 & 0.0490 .005 & 0.0380 .002 & 0.0590 .004 \\
\hline Campo Sujo de Encosta & 0.0630 .005 & 0.0410 .003 & 0.0460 .004 & 0.0360 .005 & 0.0510 .005 \\
\hline Campo Cerrado & 0.0540 .005 & 0.0370 .003 & 0.0340 .006 & 0.0300 .004 & 0.0370 .007 \\
\hline Cerrado senso estrito & 0.0620 .005 & 0.0390 .005 & 0.0440 .006 & 0.0360 .006 & 0.0440 .007 \\
\hline Cerrado com herbáceo ralo & 0.0600 .004 & +0.0380 .004 & 0.0430 .006 & $5 \quad 0.0350 .007$ & 0.0420 .004 \\
\hline Cerradão & 0.0580 .003 & 0.0380 .004 & 0.0430 .006 & 50.0350 .006 & 0.0430 .005 \\
\hline Fl. Estacional Semidecídua & 0.0560 .003 & 0.0360 .002 & 0.0390 .003 & 0.0300 .003 & 0.0390 .003 \\
\hline Floresta Ciliar & 0.0600 .006 & 0.0420 .005 & 0.0460 .007 & 0.0360 .007 & 0.0520 .008 \\
\hline Infravermelho Próximo & agosto-95 & janeiro96 & julho95 & junho97 & julho96 \\
\hline Campo Úmido & 0.1390 .010 & 0.2100 .016 & 0.1330 .010 & 0.1470 .010 & 0.1300 .015 \\
\hline Campo Limpo (Melinis) & 0.1370 .013 & 0.2220 .015 & 0.1450 .015 & 0.1620 .015 & 0.1170 .012 \\
\hline Campo (Pteridium) & 0.1330 .006 & 0.2150 .010 & 0.1310 .011 & 0.1520 .010 & 0.1180 .005 \\
\hline Campo Sujo de Encosta & 0.1330 .021 & 0.2070 .023 & 0.1300 .026 & 0.1540 .027 & 0.1260 .029 \\
\hline Campo Cerrado & 0.1200 .011 & 0.1840 .015 & 0.0880 .015 & 0.1120 .015 & 0.1050 .014 \\
\hline Cerrado senso estrito & 0.1400 .013 & 0.2030 .015 & 0.1360 .017 & 0.1580 .015 & 0.1420 .016 \\
\hline Cerrado com herbáceo ralo & 0.1520 .011 & 0.2110 .015 & 0.1470 .016 & $5 \quad 0.1600 .015$ & 0.1510 .014 \\
\hline Cerradão & 0.1580 .014 & 0.2640 .019 & 0.1720 .016 & 0.1900 .018 & 0.1790 .011 \\
\hline Fl. Estacional Semidecídua & 0.1510 .013 & 0.2180 .019 & 0.1480 .018 & 0.1700 .016 & 0.1300 .016 \\
\hline Floresta Ciliar & 0.1690 .014 & 0.2190 .022 & 0.1580 .024 & 0.1680 .019 & 0.1600 .017 \\
\hline Infravermelho Médio & agosto95 & janeiro96 & julho95 & junho97 & julho96 \\
\hline Campo Úmido & 0.1860 .017 & 0.1610 .020 & 0.1800 .022 & 0.1620 .018 & 0.2010 .021 \\
\hline Campo Limpo (Melinis) & 0.1500 .020 & 0.1280 .015 & 0.1350 .023 & 0.1200 .019 & 0.1630 .024 \\
\hline Campo (Pteridium) & 0.1470 .012 & 0.1260 .007 & 0.1330 .018 & 0.1170 .007 & 0.1540 .011 \\
\hline Campo Sujo de Encosta & 0.1410 .019 & 0.1200 .015 & 0.1190 .020 & 0.1100 .019 & 0.1340 .020 \\
\hline Campo Cerrado & 0.0850 .019 & 0.0940 .011 & 0.0520 .022 & 0.0660 .017 & 0.0700 .025 \\
\hline Cerrado senso estrito & 0.1310 .016 & 0.1110 .012 & 0.1070 .019 & 0.1040 .017 & 0.1120 .017 \\
\hline Cerrado com herbáceo ralo & 0.1250 .014 & +0.1080 .010 & 0.1010 .015 & 50.1030 .019 & 0.1080 .013 \\
\hline Cerradão & 0.1230 .014 & 0.1120 .009 & 0.1040 .015 & 50.1040 .015 & 0.1110 .014 \\
\hline Fl. Estacional Semidecídua & 0.1160 .010 & 0.1190 .008 & 0.0970 .013 & 0.0970 .009 & 0.1010 .010 \\
\hline Floresta Ciliar & 0.1220 .021 & 0.1170 .014 & 0.1100 .020 & 0.1020 .016 & 0.1260 .022 \\
\hline IVDN & agosto95 & janeiro96 & julho95 & junho97 & julho96 \\
\hline Campo Úmido & 0.2880 .050 & 0.5940 .062 & 0.3310 .059 & 0.4830 .074 & 0.2600 .049 \\
\hline Campo Limpo (Melinis) & 0.3430 .041 & 0.6700 .034 & 0.4540 .057 & 0.6020 .048 & 0.3330 .056 \\
\hline Campo (Pteridium) & 0.3570 .030 & 0.6800 .018 & 0.4920 .042 & 0.6210 .027 & 0.3040 .030 \\
\hline Campo Sujo de Encosta & 0.3730 .053 & 0.6650 .028 & 0.4170 .100 & 0.5660 .080 & 0.4590 .081 \\
\hline Campo Cerrado & 0.3540 .039 & 0.6710 .027 & 0.4760 .044 & 0.6240 .038 & 0.4250 .073 \\
\hline Cerrado senso estrito & 0.3830 .037 & 0.6790 .033 & 0.5090 .049 & 0.6380 .047 & 0.5300 .052 \\
\hline Cerrado com herbáceo ralo & 0.4340 .031 & 0.6950 .028 & 0.5500 .049 & 0.6440 .051 & 0.5630 .037 \\
\hline Cerradão & 0.4840 .030 & 0.7070 .027 & 0.5720 .049 & 0.6620 .046 & 0.5820 .044 \\
\hline
\end{tabular}


Fl. Estacional Semidecídua $0.4730 .038 \quad 0.7570 .021 \quad 0.6220 .053 \quad 0.723 \quad 0.032 \quad 0.6400 .029$

11. Glossário de termos

1-) CD-ROM = ("Compact Disk - Read Only Memory") Discos compactos de leitura óptica, estes disco prestam-se apenas a leitura de informação.

2-) Fita "streamer" = Fita magnética em cartucho com capacidade para grande quantidade de informação, servem a leitura e gravação.

3-) Imagens formatos INPE e TIFF = São formas de armazenamento da informação das imagens, os arquivos TIFF vem com as faixas espectrais reunidas num mesmo arquivo que pode ser visualizado como uma composição colorida, no formato INPE as faixas espectrais ficam em arquivos separados e podem ser visualizadas individualmente em tons de cinza.

4-) "Scanner" = Copiador óptico de imagens de qualquer alvo iluminado transformando-o em informação digital.

5-) Modelo Digital do Terreno $=$ É uma imagem que simula uma superfície tridimensional onde " $x "=$ colunas, " $y$ " = linhas e " $z$ " = altitude. A imagem é a representação do relevo da área. Esta imagem é produzida a partir das cotas de elevação previamente digitalitalizadas de mapa topográfico, transformadas em imagem e posteriormente interligadas de modo a produzir uma superfície.

6-) Modelo digital de iluminação relativa do relevo $=$ É um representação da quantidade de luz que incide sobre uma superfície (derivada do MDT) em determinada posição do Sol dada pelo ângulo de elevação solar e ângulo azimutal. Esta imagem revela as posições do relevo que recebem iluminação direta e as sombreadas ou com penumbra.

7-) Imagem de declividade = É uma imagem derivada do MDT onde cada cela da imagem tem um valor de declive, em graus ou em porcentagem.

8-) Imagem orientação de vertentes = É uma imagem derivada do MDT onde cada cela tem um valor em graus em relação ao norte.

9-) Resolução Espacial = Refere-se ao tamanho que cada cela da imagem tem no terreno (ou a capacidade que dois pontos adjacentes têm de representar a informação do terreno), na horizontal quanto a distância e na vertical e quanto à elevação.

10-) Resolução Espectral $=$ Refere-se à amplitude do espectro eletromagnético, ou seja, à quantidade de faixas do espectro eletromagnético que o sistema é capaz de sensoriar. Assim, maior resolução espectral significa maior número de faixas espectrais sensoriadas. 
11-) Resolução Radiométrica $=$ Refere-se à capacidade do sensor numa determinada faixa do espectro de discernir diferentes níveis de energia ou brilho. Geralmente está associada à forma de armazenamento da informação, ou o número de possibilidades de níveis de brilho que o sensor pode detectar.

12-) Imagens digitais formato vetorial e matricial = Imagens na forma vetorial representam pontos, linhas, arcos, polígonos e áreas por coordenadas cartesianas. Assim, cada ponto tem um valor identificador associado a um par ordenado X,Y. Este formato é econômico para armazenar informações espaciais. A forma matricial consiste numa matriz de linhas e colunas, na qual cada elemento corresponde à uma cela na imagem. Cada cela possui valor identificador que esta relacionado ao tipo de imagem. No caso das imagens geo-referenciadas as celas têm resolução espacial correspondente ao tamanho no terreno. Este formato não é econômico porém é relativamente mais fácil realizar operações matemáticas com duas ou mais imagens na forma matricial, e que constituem operações de rotina no processamento digital de imagens. 